\title{
Ciclones em Superfície nas Latitudes Austrais: Parte II Estudo de Casos
}

\author{
Michelle Simões Reboita ${ }^{1}$, Manoel Alonso Gan ${ }^{2}$, Rosmeri Porfírio da Rocha ${ }^{3}$, \\ Igor Stivanelli Custódio ${ }^{1,3}$ \\ ${ }^{1}$ Instituto de Recursos Naturais, Universidade Federal de Itajubá, Itajubá, MG, Brasil. \\ ${ }^{2}$ Instituto Nacional de Pesquisas Espaciais, São José dos Campos, SP, Brasil. \\ ${ }^{3}$ Departamento de Ciências Atmosféricas, Universidade de São Paulo, São Paulo, SP, Brasil.
}

Recebido em 10 de Março de 2016 - Aceito em 15 de Fevereiro de 2017

\begin{abstract}
Resumo
Esse trabalho apresenta a análise sinótica de quatro tipos de ciclones em latitudes austrais: extratropical do tipo Bjerknes e Solberg, extratropical do tipo Shapiro e Keyser, tropical e subtropical. Portanto, seu principal objetivo é destacar as diferenças entre esses sistemas e complementar, com análise sinótica de alguns casos, o artigo "Ciclones em Superfície nas Latitudes Austrais: Parte I Revisão Bibliográfica”, em que foi realizada uma revisão da literatura sobre os tipos de ciclones. No presente estudo, são analisados dois ciclones extratropicais ocorridos no sudoeste do oceano Atlântico Sul; o ciclone subtropical Arani também ocorrido no Atlântico Sul e um ciclone tropical, que teve gênese a nordeste da Austrália sobre o oceano Pacífico e chamado de Ului. Foram enfatizadas as características desses ciclones em quatro estágios: pré-ciclogênese, ciclogênese, maturidade (oclusão) e decaimento. Além disso, o ciclo de vida dos ciclones foi investigado através de um diagrama de fase (Cyclone Phase Space), que permite identificar o tipo de ciclone apenas com uma análise da estrutura térmica da atmosfera. Entre os resultados destacam-se que os ciclones extratropicais tiveram gênese associada à presença de gradientes horizontais de temperatura em superfície e proximidade de um cavado em 300 $\mathrm{hPa}$; que o ciclone subtropical teve um aporte dinâmico de um cavado de onda curta em $500 \mathrm{hPa}$, que foi importante para a manutenção de movimentos ascendentes na atmosfera; e que o ciclone tropical se originou numa região com fraca vorticidade relativa ciclônica em baixos níveis e convergência de massa em superfície.
\end{abstract}

Palavras-chave: estudo de caso, ciclones extratropicais, ciclones subtropicais, ciclones tropicais, ciclo de vida, Hemisfério Sul.

\section{Surface Cyclones over Austral Latitudes: Part II Cases Study}

\begin{abstract}
This work presents the synoptic analysis of four types of cyclones in southern latitudes: extratropical type Bjerknes and Solberg, extratropical type Shapiro and Keyser, tropical and subtropical. Therefore, the main purpose of this study is to highlight, with synoptic analysis of some cases, the differences between these systems and complement the article "Surface Cyclones over Austral Latitudes: Part I Bibliographic Review", in which a review of the literature about cyclones type was held. We analyzed two extratropical cyclones occurred in the Southwest South Atlantic Ocean; the subtropical cyclone called Arani, occurred in the same ocean basin and a tropical cyclone, which had genesis in the northeast of Australia over the Pacific Ocean and called Ului. The cyclones features were emphasized in four stages: pre-cyclogenesis, cyclogenesis, maturity (occlusion) and decay. Moreover, the lifecycle of the cyclones was investigated through a phase diagram (Cyclone Phase Space), which identifies the type of cyclone with only the information of the thermal structure of the atmosphere. Among the results, it is shown that the genesis of the extratropical cyclones was associated with horizontal temperature gradients in surface and a trough at $300 \mathrm{hPa}$; the subtropical cyclone had a dynamic support of a short wave trough at $500 \mathrm{hPa}$, which was important for the occurrence of upward movements in the atmosphere; and that the tropical cyclone was associated with a region of low cyclonic relative vorticity in low levels and surface mass convergence.
\end{abstract}

Keywords: case study, extratropical cyclones, subtropical cyclones, tropical cyclones, life cycle, Southern Hemisphere.

Autor de correspondência: Michelle Simões Reboita, reboita@gmail.com. 


\section{Introdução}

Os ciclones, independentemente do tipo, extratropical (seguindo o modelo de Bjerknes e Solberg, 1922 ou o modelo de Shapiro e Keyser, 1990), tropical e subtropical, são sistemas que afetam o tempo e o clima das regiões onde atuam, pois causam mudanças na temperatura, direção e intensidade dos ventos, nebulosidade e precipitação. A gênese e as características ao longo do ciclo de vida desses sistemas são particulares a cada tipo. Uma revisão detalhada das características sinóticas dos tipos de ciclones no Hemisfério Sul é apresentada em Reboita et al. (2017).

De maneira breve, os ciclones extratropicais são sistemas de baixa pressão em superfície, que se formam geralmente em latitudes maiores do que $25^{\circ} \mathrm{S}$ e que possuem gênese associada a gradientes horizontais de temperatura em superfície (região de baroclinia) e divergência de massa a jusante de cavados em médios e altos níveis da atmosfera (Charney, 1947; Celemín, 1984; Carlson, 1991; Gan e Rao, 1991; Reboita et al., 2012). Na fase de oclusão, o núcleo desses sistemas se separa do setor quente e torna-se frio por toda a troposfera (esse esfriamento começa em baixos níveis e evolui para altos níveis). Além disso, o sistema adquiri uma estrutura barotrópica equivalente. Dependendo do padrão das frentes fria e quente, os ciclones extratropicais podem seguir o modelo de Bjerknes e Solberg (1922) ou o modelo de Shapiro e Keyser (1990). No primeiro modelo, a frente fria rota ao redor do centro do ciclone, estreitando o setor com ar quente até ocorrer a oclusão. Em geral, a frente fria é mais intensa e extensa do que a frente quente. No modelo de Shapiro e Keyser (1990), a frente fria não rota ao redor do centro do ciclone e, sim, se desloca quase perpendicularmente à frente quente de maneira que quase nunca se encontram. Outras características desse tipo de ciclone são a formação de uma "ilha de ar quente" (warm seclusion) no centro do sistema e a frente quente sendo mais extensa do que a fria. Segundo Schultz et al. (1998), os ciclones do tipo Bjerknes e Solberg ocorrem associados a um escoamento difluente em altos níveis, enquanto os do tipo Shapiro e Keyser com um escoamento confluente em altos níveis.

A gênese dos ciclones tropicais ocorre, em geral, entre latitudes de $5^{\circ}$ a $20^{\circ}$, em ambos os hemisférios, e associada aos fluxos de calor latente e sensível do oceano para a atmosfera e, posterior, liberação de calor latente por condensação (Gray, 1968; Emanuel, 1991). Portanto, são sistemas não-frontais e com núcleo quente. Enquanto os ciclones extratropicais no Hemisfério Sul possuem padrão de vírgula invertida em imagens de satélite, os ciclones tropicais possuem um padrão mais simétrico.

Como menciona Hart (2003), a atmosfera é um continuum e não há somente uma divisão em ciclones extratropicais e tropicais, há um tipo intermediário que são os ciclones subtropicais. Tais sistemas ocorrem entre $15^{\circ} \mathrm{e}$ $35^{\circ} \mathrm{S}$ e podem ter gênese como subtropical ou ser provenientes da transição tropical para extratropical ou vice-versa.
Em geral, os ciclones subtropicais possuem núcleo frio em altos níveis, como os ciclones extratropicais e os Vórtices Ciclônicos de Altos Níveis (VCANs), e quente em baixos níveis, como os ciclones tropicais. Quando não há transição, a gênese dos ciclones subtropicais ocorre associada à divergência de massa a jusante de um cavado ou VCAN em níveis médios e altos da atmosfera e uma fraca baroclinia em superfície (Guishard, 2006; Evans e Braun, 2012).

Para se definir o tipo de ciclone e/ou sua evolução ao longo do ciclo de vida, um diagrama de fase-espaço ( $C y$ clone Phase Space - CPS; Hart, 2003) tem sido utilizado (Guishard et al., 2009; Dias Pinto et al., 2013; Gozzo et al., 2014). Esse diagrama descreve a estrutura térmica tri-dimensional dos ciclones através do cálculo de perturbações de altura geopotencial no núcleo dos sistemas.

A fim de complementar o artigo de Reboita et al. (2017), que é uma revisão da literatura sobre os mecanismos de gênese e evolução do ciclo de vida de quatro tipos de ciclones em latitudes austrais, o objetivo do presente trabalho é (1) apresentar um estudo de caso de cada tipo de ciclone, extratropical (tipo Bjerknes e Solberg e tipo Shapiro e Keyser), tropical e subtropical em latitudes austrais, mostrando as principais características sinóticas deles e (2) caracterizar cada tipo de ciclone através do CPS. Esse estudo (artigos Parte I e Parte II), além dos conhecimentos científicos sobre as características dos quatro tipos de ciclones, servirá de referência básica em cursos de meteorologia, uma vez que compila e mostra graficamente as características dos ciclones em latitudes austrais, o que é escasso na literatura.

\section{Dados e Metodologia}

Para a escolha dos quatro ciclones em estudo, localizados em latitudes austrais, foram utilizadas diferentes fontes de dados. Da base de dados de ciclones extratropicais do Grupo de Estudos Climáticos da Universidade de São Paulo (GREC-USP), que é elaborada e atualizada mensalmente, foram selecionados dois ciclones extratropicais: um com características do modelo conceitual de Bjerknes e Solberg e outro com características do modelo de Shapiro e Keyser. O ciclone tipo Bjerknes e Solberg teve sua gênese no dia 03 de maio de 2013, enquanto que o ciclone tipo Shapiro e Keyser, no dia 22 de novembro de 2014; e ambos têm posição inicial entre o extremo sul do Brasil e Uruguai (Fig. 1).

Para a escolha do ciclone subtropical, verificou-se a lista de sistemas subtropicais que receberam nome pela Marinha Brasileira. Como o primeiro sistema que ganhou nome desse órgão foi o Arani, optou-se por esse sistema (Fig. 1). Este ciclone se formou no dia 13 de março de 2011, no estado do Espírito Santo (Fig. 1). É interessante ressaltar que o ciclone subtropical denominado de Anita (Dias Pinto et al., 2013), ocorrido antes do Arani, não teve seu nome por sugestão da Marinha Brasileira, mas por alguns centros regionais de meteorologia. 


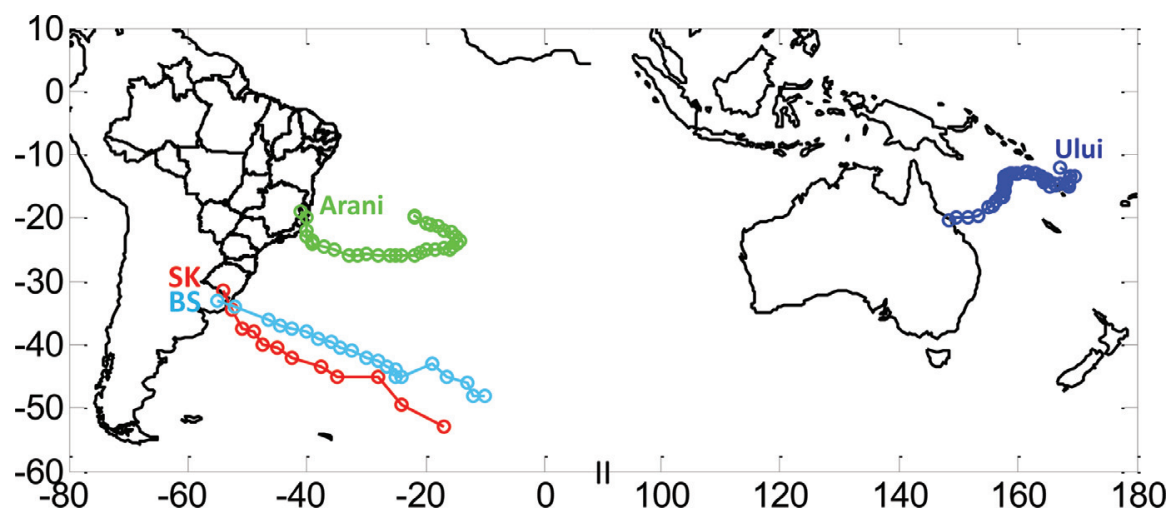

Figura 1 - Localização a cada 6 h do ciclone extratropical tipo Bjerknes e Solberg (BS; azul claro), do ciclone extratropical tipo Shapiro e Keyser (SK, vermelho), do ciclone subtropical Arani (verde) e do ciclone tropical Ului (azul). O nome de cada sistema está próximo a primeira posição observada (ciclogênese).

Com relação ao ciclone tropical selecionado para o estudo, este teve gênese no dia 10 de março de 2010, nas águas do oceano Pacífico Sul ao nordeste da Austrália (Fig. 1). Este caso foi escolhido aleatoriamente no portal de dados de ciclones tropicais da Universidade de Melbourne (Southern Hemisphere Tropical Cyclone Data Portal) e é denominado, em tal base de dados, de Ului.

Como os ciclones extratropicais e o subtropical escolhidos tiveram gênese no sudoeste do oceano Atlântico Sul era de se esperar que o Furacão Catarina fosse escolhido para representar o ciclone tropical. Como esse furacão não foi bem representado nas análises numéricas (Gan et al., 2006) e surgiu de uma transição extratropical (McTaggart e Cowan, 2006), para fins didáticos, escolheu-se o ciclone Ului que é um caso clássico de ciclogênese tropical, ao invés do ciclone Catarina.

Para realizar o estudo sinótico dos quatro ciclones foi utilizada a análise do Global Forecast System (GFS). Essa análise possui resolução espacial de $0,5^{\circ} \times 0,5^{\circ}$ de latitude e longitude, 26 níveis verticais de pressão e disponibilização dos dados nos quatro horários sinóticos padrão (0000, 0600, 1200 e 1800 Z). Para o caso do ciclone tropical, também foram utilizados dados semanais médios e de anomalias de temperatura da superfície do mar (SST) obtidos do conjunto NOAA Optimum Interpolation (OI) Sea Surface Temperature (SST) V2. Esses dados cobrem o período de 1981 ao presente, possuem resolução horizontal de $1,0^{\circ}$ (Reynolds et al., 2007).

As imagens de satélite utilizadas originaram-se de diferentes fontes. No caso do ciclone extratropical do tipo Bjerknes e Solberg e do ciclone subtropical foram utilizadas imagens do canal infravermelho do satélite GOES-12 obtidas do NOAA Satellite and Information Service. Deste mesmo local, foram provenientes as imagens do satélite METEOSAT1R, também do canal infravermelho, para o estudo do ciclone tropical. Por fim, para o ciclone extratropical tipo Bjerknes e Solberg obtiveram-se as imagens do satélite GOES-13 do Centro de Previsão de Tempo e Estudos Climáticos (CPTEC).
Em meteorologia sinótica existem algumas variáveis chaves que são usadas para analisar as características dos sistemas atmosféricos e entre elas estão: a pressão atmosférica ao nível médio do mar (PNMM), altura geopotencial, espessura da camada (que é a diferença da altura geopotencial entre duas superfícies de pressão constante e que é proporcional à média da temperatura do ar na camada), advecção horizontal de temperatura do ar, vorticidade relativa, velocidade vertical (ômega) e intensidade e direção do vento. Todas essas variáveis são apresentadas na análise dos quatro ciclones. Para os ciclones extratropicais e subtropical foi calculada a espessura da camada $500 / 1000 \mathrm{hPa}$, enquanto que para o ciclone tropical, $850 / 1000 \mathrm{hPa}$. Como a variação vertical da temperatura do ar é pequena nos trópicos, a espessura entre 500/1000 hPa não mostra muita variação, sendo, portanto, mais adequado o uso de $850 / 1000 \mathrm{hPa}$.

Juntamente com as variáveis altura geopotencial em 1000 e $300 \mathrm{hPa}$ e advecção horizontal de temperatura do ar em $1000 \mathrm{hPa}$ será ilustrada a posição dos sistemas frontais para os casos de ciclogêneses extratropical. A identificação desses sistemas é realizada com base na análise conjunta das variáveis citadas e com os campos de pressão atmosférica e espessura da camada (detalhes sobre a análise de cartas sinóticas podem ser obtidos em Celemín, 1984 e Stull, 2000).

Para cada caso de ciclone estudado foram mostrados quatro estágios: pré-ciclogênese (período que precede a formação do ciclone), ciclogênese (quando aparecem isóbaras fechadas na região do ciclone), maturidade (quando o ciclone chega a sua máxima intensidade durante a fase de oclusão) e decaimento (enfraquecimento do sistema após a oclusão).

\section{Resultados}

\subsection{Ciclone extratropical do tipo Bjerknes e Solberg}

O ciclone extratropical que teve gênese entre o Uruguai e o Rio Grande do Sul no dia 03 de maio de 2013 segue 
o modelo conceitual de Bjerknes e Solberg (1922), pois sua evolução sinótica mostra a frente fria rotando em torno do centro de baixa pressão e em direção à frente quente, até ocorrer o processo de oclusão. Além disso, o padrão das isotermas em $850 \mathrm{hPa}$ se assemelha ao do modelo conceitual mostrado na Fig. 5a de Reboita et al. (2017).

\subsubsection{Pré-Ciclogênese (0600Z do dia 03/05/2013)}

O ambiente sinótico prévio à gênese do ciclone extratropical é caracterizado pela presença de uma região de baixa pressão ao norte de $30^{\circ} \mathrm{S}$ na Argentina (Fig. 2a-b; Fig. 3a) que pode estar relacionada a dois fatores: a baixa termo-orográfica que é uma característica típica do noroeste argentino (Seluchi et al., 2003) e a divergência de massa ocorrida a jusante de um cavado em $300 \mathrm{hPa}$ (Fig. 2b) que tem eixo sobre a Argentina (divergência em altos níveis favorece o desenvolvimento de movimentos ascendentes e convergência em superfície, Fig. 5c). Já sobre o Uruguai e ao sul deste país (Fig. 2a), há um gradiente horizontal de temperatura do ar que é representado pela proximidade das linhas de espessura entre
$500 / 1000 \mathrm{hPa}$ e por ventos relativamente intensos em $200 \mathrm{hPa}$, provenientes de tal gradiente. Uma configuração espacial similar a das linhas de espessura (Fig. 2a) é obtida nas isotermas em $850 \mathrm{hPa}$ (Fig. 3a). A combinação dos padrões atmosféricos descritos juntamente com os movimentos ascendentes na atmosfera (Fig. $4 \mathrm{~b}$ e Fig. 5c) contribuem para a ocorrência de nebulosidade como mostra a imagem do satélite GOES-12 no canal infravermelho (Fig. 3b).

Para complementar as informações apresentadas, também são mostrados perfis verticais do desvio zonal de temperatura do ar (Fig. 4b) e altura geopotencial (Fig. 5b; calculados com todas as longitudes incluídas nas figuras, no caso, $70^{\circ} \mathrm{W}$ a $0^{\circ}$ ) e vorticidade relativa ciclônica (Fig. 5a), velocidade vertical (ômega) e divergência de massa (Fig. 5c). Sob a jusante do cavado em $300 \mathrm{hPa}$, há uma região de intensos movimentos ascendentes e predomínio de desvio positivo de temperatura do ar da superfície a cerca de $850 \mathrm{hPa}$ (aproximadamente $67^{\circ} \mathrm{W}$; Fig. 4b). Os perfis verticais de vorticidade relativa ciclônica (Fig. 5a) e de desvio negativo de altura geopotencial (Fig. 5b) pos-

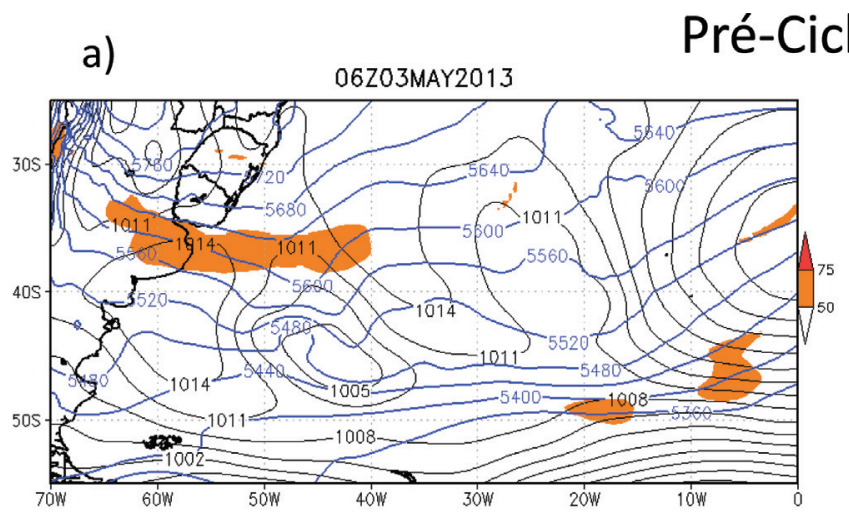

b)
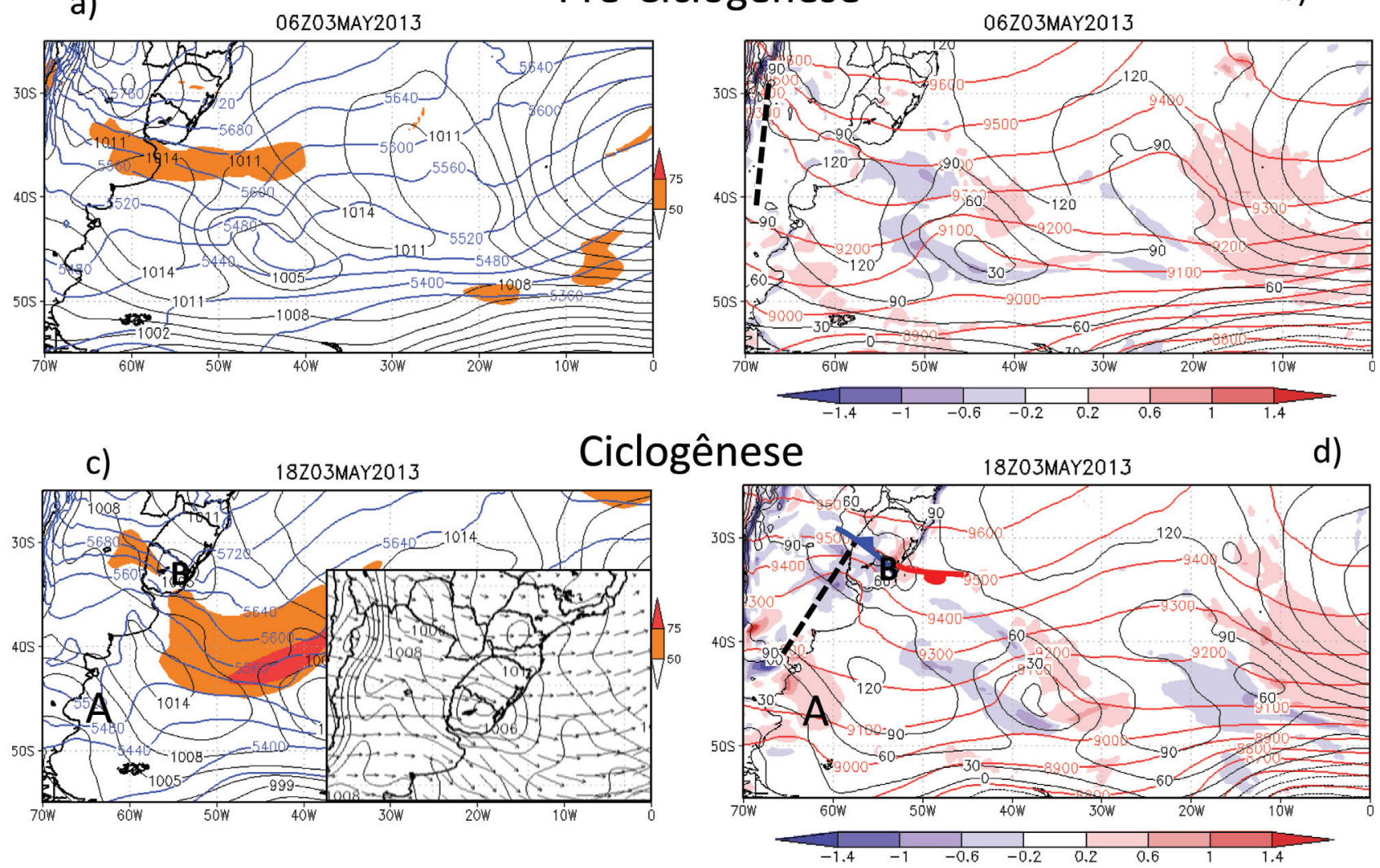

Figura 2 - Ciclo de vida do ciclone extratropical do tipo Bjerknes e Solberg nos estágios: pré-ciclogênese (a-b), ciclogênese (c-d), maturidade (e-f) e decaimento (g-h). A coluna da esquerda mostra a pressão ao nível médio do mar (hPa, linha preta), a espessura da camada 500/1000 hPa (metros, linha azul) e a intensidade do vento $\left(\mathrm{m} \mathrm{s}^{-1}\right) \mathrm{em} 200 \mathrm{hPa}$ (preenchido). Em (c) também é mostrado um zoom no ciclone em superfície (representado pela PNMM em linhas contínuas) e nos ventos em $200 \mathrm{hPa}$ (vetores). A coluna da direita apresenta a altura geopotencial em $1000 \mathrm{hPa}$ (linha preta) e em $300 \mathrm{hPa}$ (linha vermelha), a advecção horizontal de temperatura do ar em $1000 \mathrm{hPa}\left({ }^{\circ} \mathrm{C} /\right.$ hora, preenchido) e a localização das frentes fria (linha azul com triângulos), quente (linha vermelha com semicírculos) e oclusa (linha com alternância de triângulos e semicírculos roxos). Nas figuras, a letra B indica a localização do centro de baixa pressão, enquanto a linha preta tracejada a posição dos cavados em $300 \mathrm{hPa}$. 

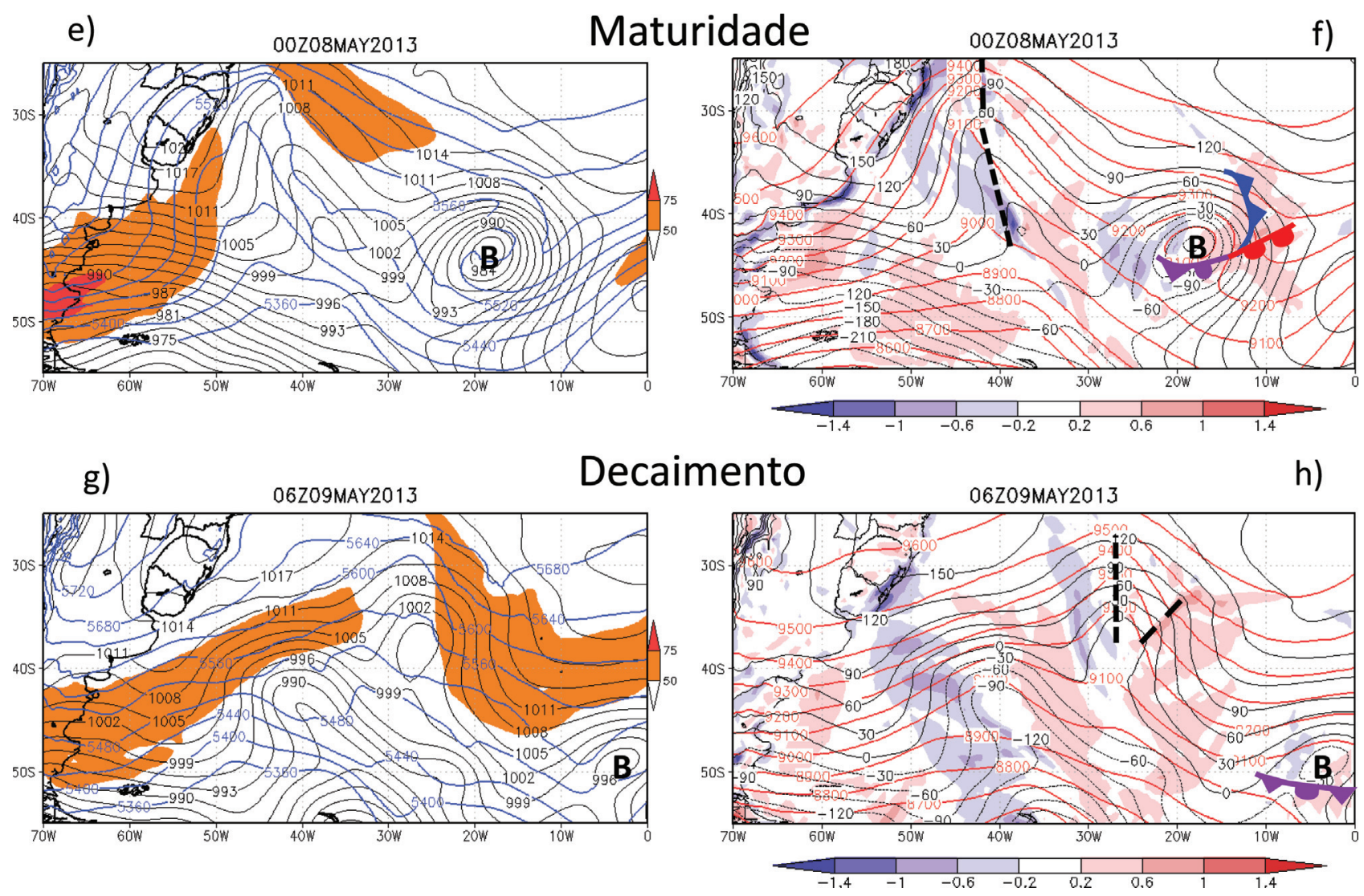

Figura 2 - Continuação.

suem padrão similar, isto é, um núcleo mais intenso nos altos níveis entre $350-200 \mathrm{hPa}$ e em torno de $68^{\circ} \mathrm{W}$.

Quanto à nebulosidade mostrada na Fig. 3b, essa se difere do modelo conceitual de Troup e Streten (1972), mostrado na Fig. 6 de Reboita et al. (2017), pois não apresenta a fase onda, como no modelo conceitual. Esse fato está associado à gênese de ciclones por influência topográfica quando cavados ou VCANs cruzam os Andes em direção ao oceano Atlântico (que é a situação em estudo).

\subsubsection{Ciclogênese (1800Z do dia 03/05/2013)}

Às $1800 Z$ do dia 03 de maio de 2013, entre o Uruguai e o estado do Rio Grande do Sul, surgem isolinhas fechadas de PNMM (Fig. 2c), com pressão central de 1005 hPa, e de altura geopotencial em $1000 \mathrm{hPa}$, com valor de $60 \mathrm{~m} \mathrm{em}$ torno de $55^{\circ} \mathrm{W}$ e $33^{\circ} \mathrm{S}$ (Fig. 2d), caracterizando a gênese do ciclone. Tal ciclogênese é explicada pela interação da divergência de massa a jusante do cavado em $300 \mathrm{hPa}$ (Fig. 2d e 5f) com uma região de gradiente horizontal de temperatura do ar (região de baroclinia) em baixos níveis no extremo sul do Brasil e Uruguai (Fig. 2c). De fato, do estágio pré-ciclogênese para o atual, o cavado em $300 \mathrm{hPa}$ se desloca para leste (Figs. 2b-d). Com isso, seu setor a jusante propicia divergência de massa em altos níveis e movimentos ascendentes na atmosfera (Fig. 5f) e esses, por sua vez, ocorrem na região com baroclinia em superfície, entre $30^{\circ}-35^{\circ} \mathrm{S}$ (Fig. 2c). Em suma, a combinação desses mecanismos fornece as condições propícias para a ciclogênese que segue o modelo conceitual mostrado na Fig. 4b de Reboita et al. (2017). Os campos sinóticos em altos níveis também estão em concordância com o estudo de Schultz et al. (1998), isto é, o posicionamento do jato em altos níveis e as linhas de altura geopotencial em $300 \mathrm{hPa}$, bem como os vetores do vento em $200 \mathrm{hPa}$ (Fig. 2c), indicam que o ciclone do tipo Bjerknes e Solberg ocorre na região com escoamento difluente em altos níveis.

Um fato que merece destaque é que os cavados em médios/altos níveis que se deslocam do oceano Pacífico em direção ao oceano Atlântico nas latitudes a cerca de $30^{\circ}-35^{\circ} \mathrm{S}$ não estão associados com ciclogêneses imediatamente após cruzarem os Andes e, sim, a cerca de $1000 \mathrm{~km}$ destes (Vera et al., 2002), na região costeira do Uruguai e Rio Grande do Sul. Conforme Reboita et al. (2012), a gênese dos ciclones ocorre pela associação de alguns mecanismos: divergência a jusante do cavado transiente em médios/altos níveis associada com a do cavado estacionário originado por efeito da topografia andina (Satyamurty et al., 1980; Lenters and Cook, 1997), baroclinia em superfície favorecida pela confluência das correntes do Brasil e das Malvinas e, em muitos casos, suporte de umidade pelo jato de baixos níveis a leste dos Andes. 
Continuando a análise do ciclone, a configuração espacial das linhas de espessura na camada entre 500/1000 hPa (Fig. 2c) e da temperatura em $850 \mathrm{hPa}$ (Fig. 3c) são similares (com formato de cavado invertido sobre o Uruguai e sul do Brasil) e representam o estágio I do campo de temperatura do ciclo de vida de um ciclone tipo Bjerknes e Solberg (1922), como mostrado na Fig. 5a de Reboita et al. (2017). Outras características interessantes na gênese do ciclone é que as linhas de espessura da camada cruzam o centro do ciclone, indicando a existência de baroclinia (Fig. 2c) e que com o desenvolvimento da circulação no ciclone em superfície (Fig. 4c) se formam as frentes fria e quente, bem como, a ocorrência de advecção horizontal de ar frio na retaguarda da frente fria e de uma pequena região com advecção de ar quente no setor da frente quente (Fig. 2d). Como as frentes são regiões de gradientes horizontais de temperatura do ar, logo, em altos níveis, aparecem ventos intensos (jatos; Fig. 2c), como esperado segundo a equação do vento térmico (Stull, 2000). $\mathrm{O}$ jato em $200 \mathrm{hPa}$ tende a cruzar o centro do ciclone, o que não vai ocorrer na etapa de maturidade, pois o ciclone ficará no lado polar do jato. Ainda se tratando de modelos conceituais, no estágio de ciclogênese a nebulosidade registrada no canal infravermelho do satélite GOES-12 tem padrão similar ao descrito por Troup e Streten (1972), ou seja, na fase de ciclogênese dos sistemas extratropicais, a nebulosidade já possui a forma de vírgula invertida no Hemisfério Sul (Fig. 3d).

Com o deslocamento do cavado em $300 \mathrm{hPa}$ para leste (Fig. 2d), também ocorre o deslocamento do tubo de vorticidade relativa ciclônica e dos desvios zonais de altura geopotencial para leste (Fig. 5d-e). Com relação a primeira variável citada, a cerca de $55^{\circ} \mathrm{W}$ há um intenso tubo de vorticidade relativa ciclônica alongado verticalmente entre 1000 e $200 \mathrm{hPa}$ e que se localiza em superfície na mesma região em que há intensa convergência (Fig. 5f). Na realidade, o tubo de vorticidade corresponde à junção da vorticidade relativa ciclônica do sistema de baixa pressão em superfície (máximos absolutos de vorticidade entre a superfície e cerca de $700 \mathrm{hPa}$ ) com a do centro do cavado em altos níveis da atmosfera (máximos absolutos de vorticidade entre 400 e $200 \mathrm{hPa}$ ); como na fase de intensificação do ciclone em superfície o cavado em altos níveis fica localizado a oeste desse, o tubo de vorticidade apresenta inclinação para oeste à medida que a altitude aumenta. Uma vez que os cavados são dominados por ar frio, isso favorece um

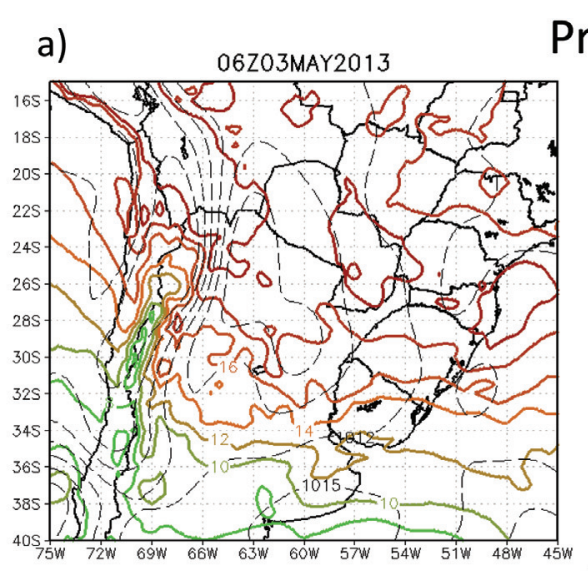

Pré-Ciclogênese

c)

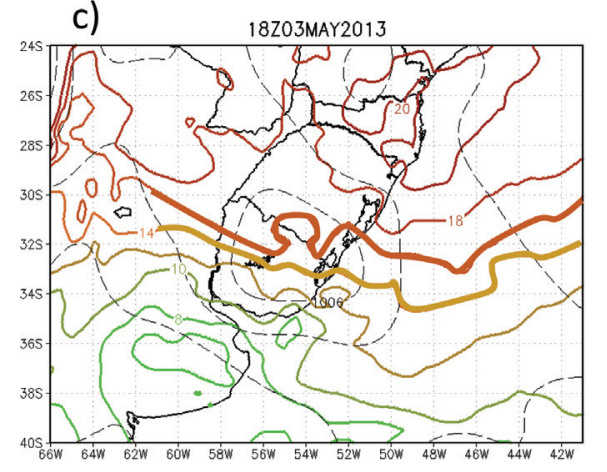

$06 Z 03$ May2013

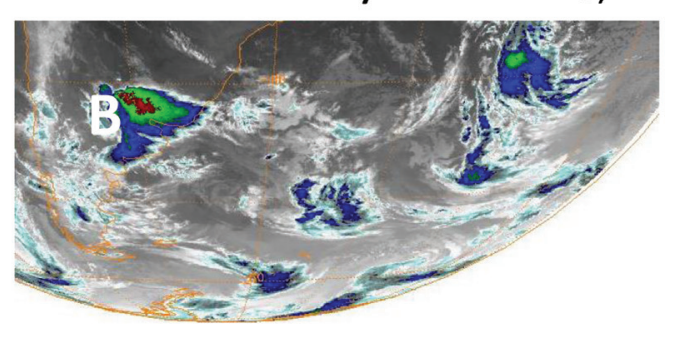

b)

\section{Ciclogênese}

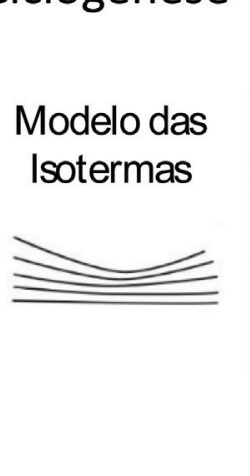

18Z03May2013

d)

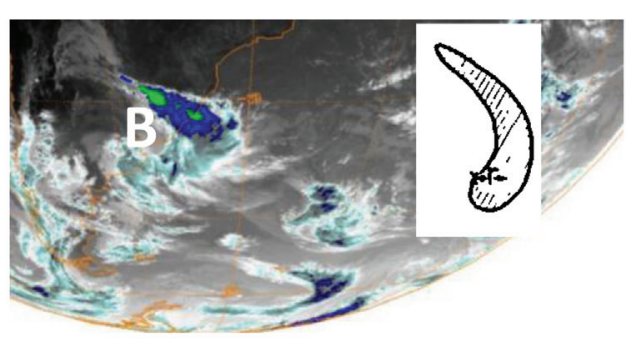

Figura 3 - Ciclo de vida do ciclone extratropical do tipo Bjerknes e Solberg nos estágios: pré-ciclogênese (a-b), ciclogênese (c-d), maturidade (e-f) e decaimento $(\mathrm{g}-\mathrm{h})$. A coluna da esquerda apresenta as isotermas em $850 \mathrm{hPa}\left({ }^{\circ} \mathrm{C}\right.$, linhas coloridas) e a pressão atmosférica ao nível médio do mar (hPa, linhas tracejadas) e a coluna da direita, as imagens do satélite GOES-12 no canal infravermelho. Nas figuras, a letra B indica a localização do ciclone. Também são apresentados os modelos conceituais das isotermas do ciclone tipo Bjerknes e Solberg e do padrão da nebulosidade em ciclones extratropicais observado em imagens de satélite, seguindo Troup e Streten (1972). Para ressaltar a similaridade das isotermas do caso estudado com o do modelo, aumentou-se a espessura de algumas isotermas. 

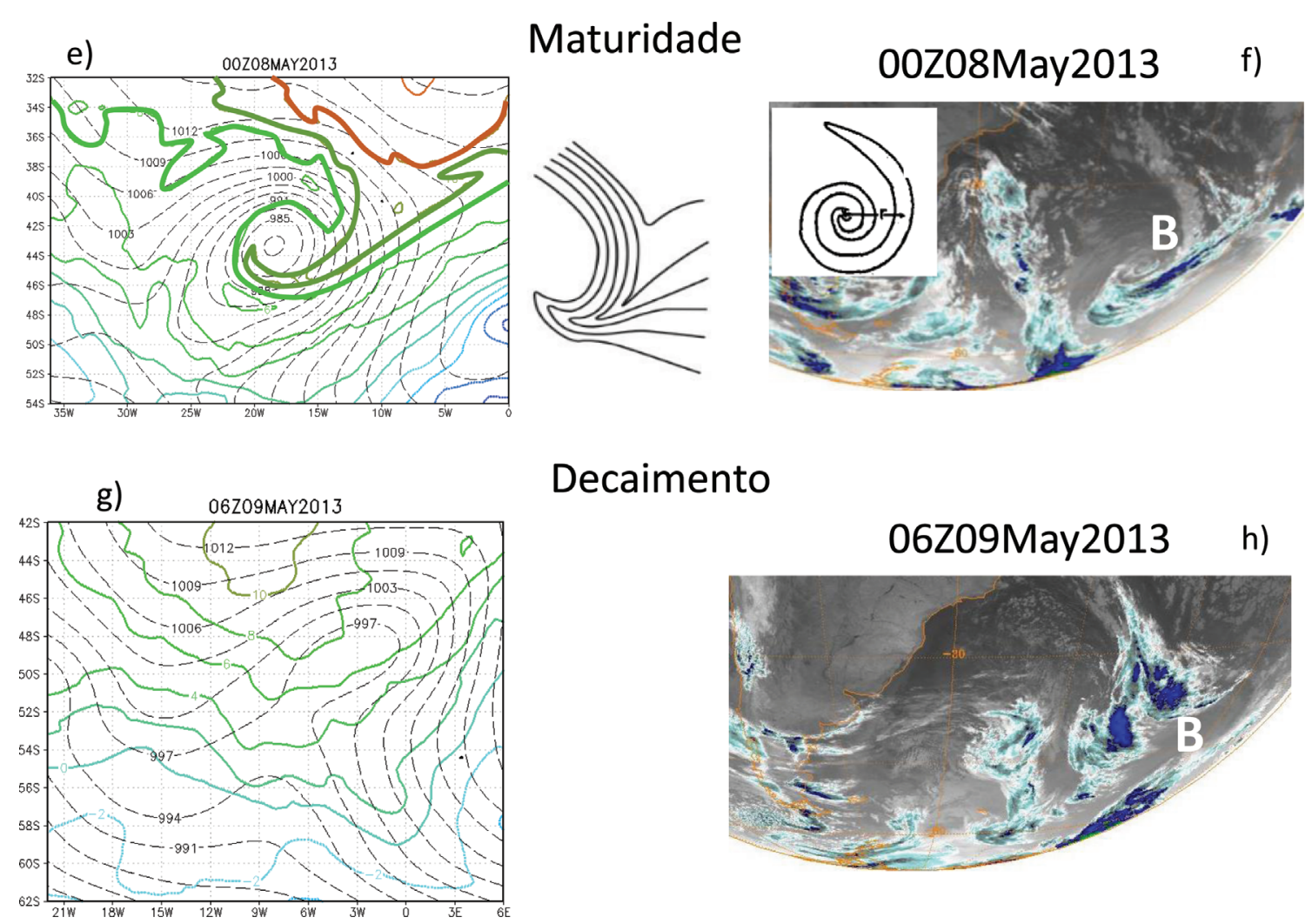

\section{Decaimento}

Figura 3 - Continuação.

decréscimo rápido da pressão (espessura) com a altura implicando em menor altura geopotencial. Como o centro de um ciclone é uma região de baixa pressão atmosférica, também possui menores valores de altura geopotencial do que uma região com maiores pressões. Dessa forma, os desvios negativos de altura geopotencial (Fig. 5e) ao conectarem o ciclone em superfície com o cavado em $200 \mathrm{hPa}$ também se inclinam para oeste com o aumento da altura.

A análise da seção vertical dos desvios zonais de temperatura do ar no centro do ciclone indica que há ar mais quente a leste da posição central desse sistema (que é cerca de $55^{\circ} \mathrm{W}$ ) e ar mais frio a oeste. À medida que o ar frio (mais denso) avança em direção à região de ar relativamente mais quente (menos denso), esse último se eleva na atmosfera, o que justifica os movimentos ascendentes na Fig. 4d. Para facilitar o entendimento de tal figura, foram traçados nela os limites das zonas frontais fria e quente de forma que o leitor consiga compará-la com a Fig. 3c de Reboita et al. (2017) e com as que mostram modelos conceituais em livros textos, como a Fig. 11.25a do Ahrens (2008). Também é importante mencionar no perfil vertical (Fig. 4d), que os desvios positivos de temperatura se estendem da superfície até cerca de $300 \mathrm{hPa}$ sendo mais intensos entre 700 e $350 \mathrm{hPa}$ (a cerca de $56^{\circ} \mathrm{W}$ ), nos mesmos níveis onde os movimentos ascendentes são mais intensos.

\subsubsection{Maturidade (0000Z do dia 08/05/2013)}

No período de desenvolvimento do ciclone em superfície, o cavado em altos níveis se desloca mais rápido para leste do que o ciclone de forma que às $0000 \mathrm{Z}$ do dia $08 \mathrm{de}$ maio o centro do cavado em $300 \mathrm{hPa}$ está em fase com o ciclone em superfície (Fig. 2f), caracterizando um ambiente barotrópico. Quando isso ocorre significa que o ciclone atingiu sua intensidade máxima e que a etapa seguinte será de decaimento. Antes do ciclone chegar à intensidade máxima, que no caso atingiu a pressão central de $984 \mathrm{hPa}$ (Fig. 2e), a frente fria vai rotando em direção à quente até "tomar o lugar" da mesma, o que origina a frente oclusa e, portanto, diz-se que o ciclone está ocluso (Fig. 2f). Nessa etapa, não há mais linhas de espessura (gradiente horizontal de temperatura do ar) cruzando o centro do ciclone. Agora essas linhas tendem a contornar o centro da baixa pressão. A Fig. 3e, que representa as isotermas em $850 \mathrm{hPa}$, indica bem esse padrão das linhas de mesma temperatura contornando o centro do ciclone e, além disso, se assemelha ao modelo das isotermas de temperatura em $850 \mathrm{hPa}$ do estágio IV do ciclo de vida dos ciclones extratropicais do tipo Bjerknes e Solberg (Fig. 5a de Reboita, 2017). Também é nessa fase do ciclo de vida dos ciclones que a nebulosidade possui um padrão de espiral (Fig. 3f), o que concorda com o modelo de nebulosidade descrito por Troup e Streten (1972). 
Como na fase de oclusão não há mais gradientes horizontais de temperatura do ar cruzando o centro do ciclone, também não haverá jatos em altos níveis atravessando o mesmo. Nessa etapa do ciclo de vida, o ciclone se localiza no lado polar do jato em altos níveis (Fig. 2e).

Na fase de oclusão (Figs. 5g-h), o tubo de vorticidade relativa ciclônica e os desvios zonais negativos de altura geopotencial não apresentam inclinação, indicando a existência de uma atmosfera barotrópica. Analisando a estrutura vertical da atmosfera, observa-se que o centro do cavado em $300 \mathrm{hPa}$ está acoplado com o ciclone em superfície (Fig. 2f) e é nesse período que o tubo de vorticidade relativa ciclônica atinge sua máxima intensidade e se estende por toda a coluna atmosférica (Fig. 5g). Como o setor a jusante do cavado não contribui mais com a divergência necessária para a manutenção do ciclone, a convergência em superfície enfraquece (Fig. 5i).
Como mostrado na Fig. 3e, a Fig. 4e também revela que o ciclone possui temperatura do ar quase homogênea no seu centro. Considerando o nível de $925 \mathrm{hPa}$ (Fig. 4e), a temperatura é de aproximadamente $13{ }^{\circ} \mathrm{C}$. Embora o modelo conceitual de Bjerknes e Solberg (1922) mencione que o centro do ciclone se torna frio em baixos níveis na fase de oclusão, isso não é visualizado no perfil vertical dos desvios zonais de temperatura do ar, pois como a onda atmosférica transportou ar quente para as latitudes mais altas (que são climatologicamente mais frias) isso impactou os desvios zonais, indicando a ocorrência de temperaturas mais elevadas no centro do ciclone.

\subsubsection{Decaimento (0600Z do dia 09/05/2013)}

Sem o suporte da divergência de massa a jusante do cavado em $300 \mathrm{hPa}$ (Fig. 2h) e sem gradientes horizontais de temperatura do ar em superfície (Fig. 2g), não há mais

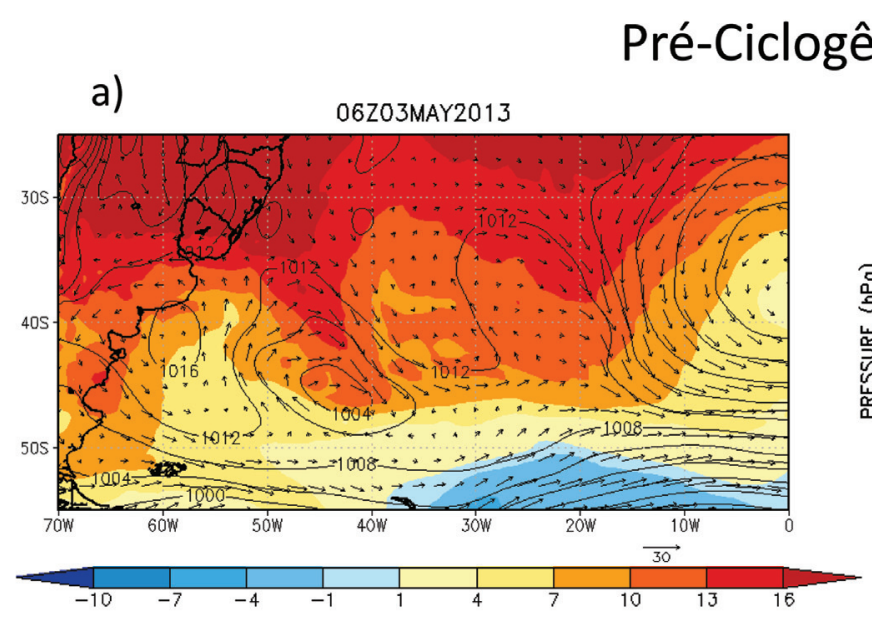

ênese

b)

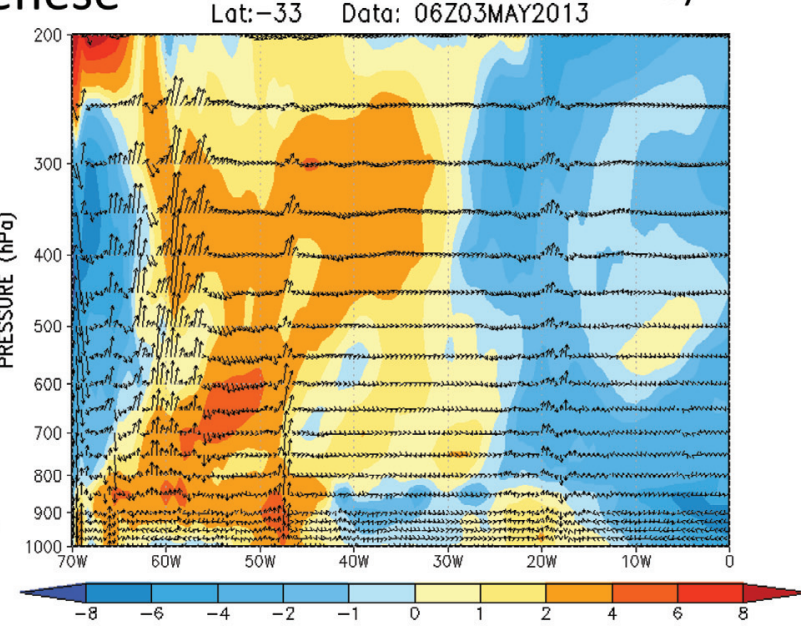

c)

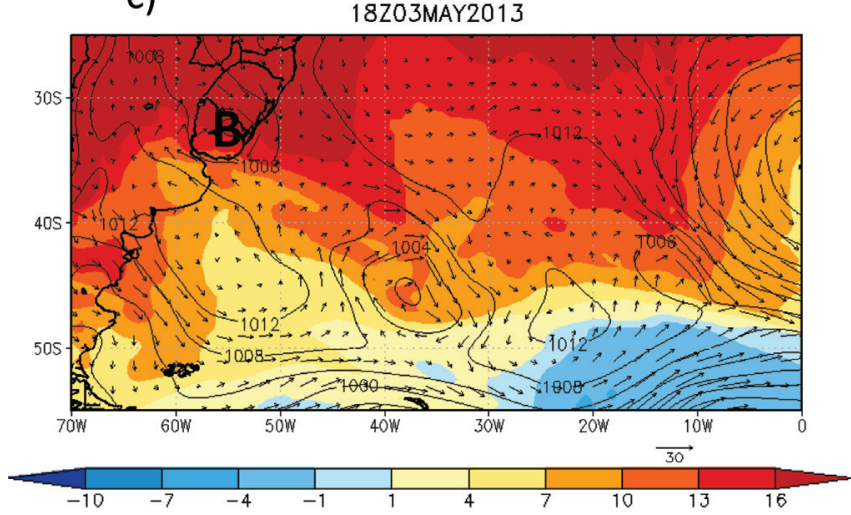

Ciclogênese

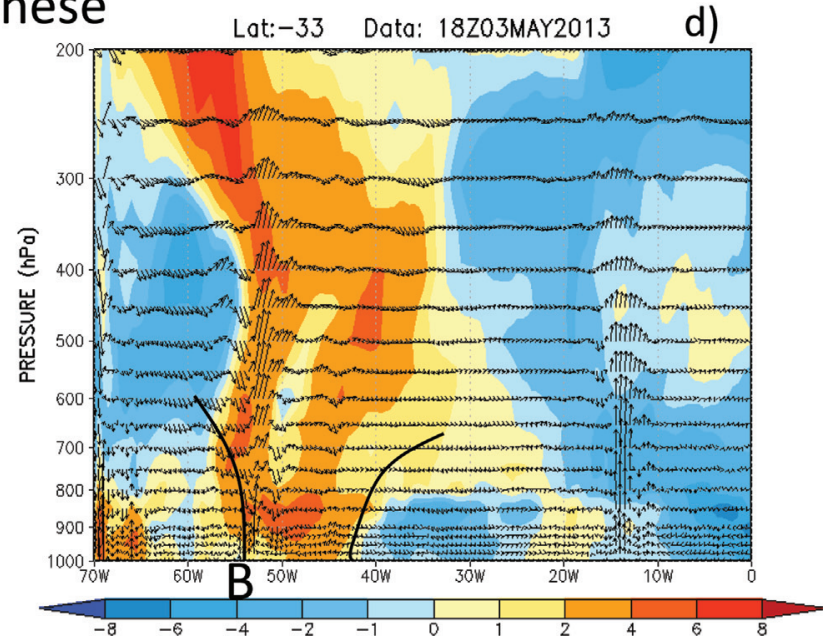

Figura 4 - Ciclo de vida do ciclone extratropical nos estágios: pré-ciclogênese (a-b), ciclogênese (c-d), maturidade (e-f) e decaimento (g-h). A coluna da esquerda mostra a pressão ao nível médio do mar ( $\mathrm{hPa}$, linha preta), a temperatura do ar $\left({ }^{\circ} \mathrm{C}\right.$ preenchido) e a direção do vento (setas) em 925 hPa. Já a coluna da direita apresenta um corte vertical do desvio zonal de temperatura do ar $\left({ }^{\circ} \mathrm{C}\right.$ preenchido) e o movimento vertical (setas). O desvio zonal foi determinado subtraindo-se os valores da temperatura de cada nível vertical da média dessa variável, por nível, computada com todas as longitudes mostradas na figura. A circulação vertical foi obtida através da componente zonal do vento ( $\mathrm{m} \mathrm{s}^{-1}$ ) e da velocidade vertical (Pascal/s) multiplicada por -100. Nas figuras, a letra B indica a localização do ciclone. Na figura d foi indicada a localização das superfícies frontais com linhas pretas. 

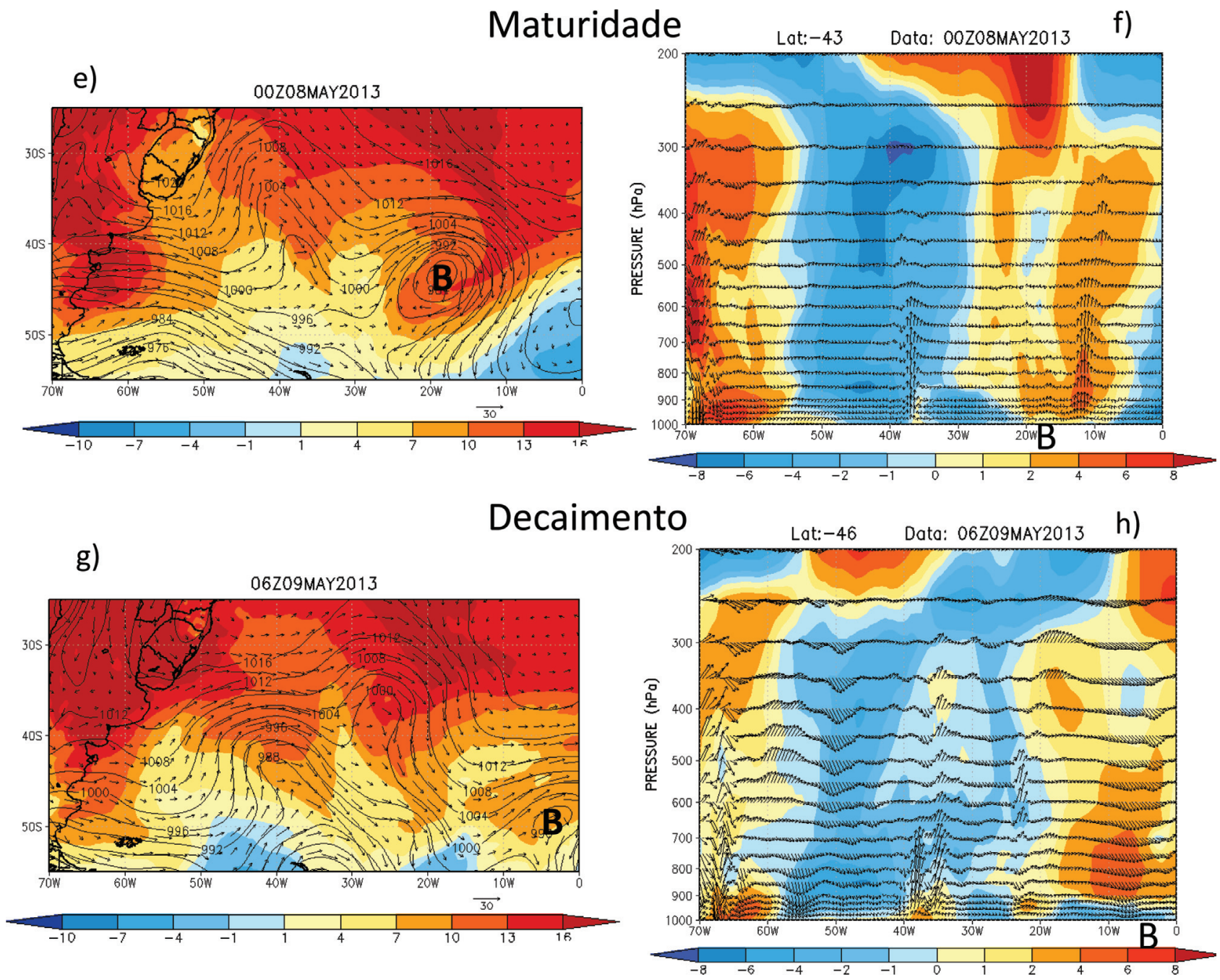

Figura 4 - Continuação.

energia potencial disponível para ser convertida em cinética. Portanto, há enfraquecimento dos movimentos ascendentes na atmosfera (Fig. 4h e Fig. 5l) e o ciclone tende a enfraquecer e se dissipar. Nesse estágio do ciclo de vida, o centro de baixa pressão localiza-se deslocado para sudeste em relação a sua posição na fase de maturidade e embebido numa massa de ar com temperaturas a cerca de $7{ }^{\circ} \mathrm{C}$ (Fig. 4g). Além disso, o tubo de vorticidade relativa ciclônica (Fig. 5j) se inclina, ligeiramente, para leste (característica típica do decaimento dos sistemas baroclínicos) e não há mais desvios negativos de altura geopotencial na região do ciclone, ao contrário, os desvios tornaram-se positivos e o movimento vertical é descendente na região do ciclone (Fig. 5k). No campo de nebulosidade, o padrão de espiral já começa a se desorganizar (Fig. 3h).

Com relação ao perfil vertical dos desvios zonais de temperatura do ar (Fig. 4h), nota-se que o ar frio domina no centro da baixa próximo à superfície, mas ainda há anomalias positivas acima destas. Esse padrão de ar frio sob ar quente propicia uma atmosfera mais estável termodinami- camente e com menos possibilidade de converter a energia potencial em cinética. Isso causa o decaimento do ciclone.

\subsection{Ciclone extratropical do tipo Shapiro e Keyser}

O ciclone extratropical analisado nessa seção segue o modelo conceitual de Shapiro e Keyser (1990), uma vez que sua evolução sinótica mostra a presença da warm seclusion e as frentes fria e quente exibindo padrão T-bone. Além disso, as isotermas em $850 \mathrm{hPa}$ mostram o mesmo comportamento do modelo conceitual exibido na Fig. $5 \mathrm{~b}$ de Reboita et al. (2017).

\subsubsection{Pré-Ciclogênese (0600Z do dia 21/11/2014)}

O estágio pré-ciclogênese é caracterizado por uma região de intenso gradiente horizontal de temperatura do ar em baixos níveis da atmosfera $\left(35^{\circ} \mathrm{S}-52^{\circ} \mathrm{W}\right)$, como indicado pela espessura da camada 500/1000 hPa na Fig. 6 a. Tal região de intenso gradiente de temperatura, associado à frente estacionária sobre o continente na fronteira entre $o$ Uruguai e Rio Grande do Sul, é decorrente do escoamento 
confluente produzido por dois anticiclones: um com centro em $28^{\circ} \mathrm{W}-35^{\circ} \mathrm{S}$ e outro em $58^{\circ} \mathrm{W}-40^{\circ} \mathrm{S}$ (Figs. 6a e $8 \mathrm{a}$ ). Com base nas análises do dia 21/11/2014, a frente fria não apresentou deslocamento significativo em relação ao dia anterior sobre o continente (figs. não mostradas), por isso que foi considerada como frente estacionária nesse setor.

A região frontal também é indicada no campo de advecção horizontal de temperatura do ar em $1000 \mathrm{hPa}$, onde predomina advecção fria na retaguarda da frente fria, localizada sobre o oceano Atlântico, e quente na sua dianteira (Fig. 6b), e por uma banda de nebulosidade um pouco difusa (Fig. 7b). Como nas regiões em que há intenso gradiente horizontal de temperatura do ar em superfície os ventos aumentam sua intensidade com a altura, sobre a região frontal nota-se ventos em $200 \mathrm{hPa}$ com intensidade chegando a $50 \mathrm{~m} \mathrm{~s}^{-1}$ (Fig. 6a). Parte da região com ventos intensos $\left(35^{\circ} \mathrm{S}-50^{\circ} \mathrm{W}\right)$ localiza-se a jusante de um cavado em $300 \mathrm{hPa}$ que está sobre o sudeste da América do Sul (Fig. 6b). Com relação à vorticidade relativa ciclônica, no setor da frente estacionária sobre o Rio Grande do Sul, essa variável tem fraca assinatura até $800 \mathrm{hPa}$ (Fig. 9a). A descrição apresentada mostra que os gradientes horizontais de temperatura do ar em superfície e a proximidade de um cavado em $300 \mathrm{hPa}$ são os precursores da ciclogênese, o que concorda com os modelos conceituais descritos em Reboita et al. (2017).

\subsubsection{Ciclogênese (0600Z do dia 22/11/2014)}

No estágio da gênese do ciclone extratropical, a alta pressão que se localizava em $58^{\circ} \mathrm{W}-40^{\circ} \mathrm{S}$ migrou para leste $\left(35^{\circ} \mathrm{W}-42^{\circ} \mathrm{S}\right)$ deixando o ambiente mais favorável para o desenvolvimento do ciclone (Fig. 6c). A gênese do ciclone é marcada por algumas características: (a) linhas de espessura 500/1000 hPa cruzando o centro da baixa recém formada indicando a presença de um ambiente baroclínico (Fig. 6c), (b) presença das frentes fria e quente (Fig. 6d) que tendem a se assemelhar ao padrão T-bone (onde a frente fria se deslocará de maneira quase perpendicular à frente quente) do modelo de Shapiro e Keyser (1990), (c) intensa advecção fria na retaguarda da frente fria alcançando cerca de $-12{ }^{\circ} \mathrm{C} /$ dia e uma área de advecção quente na retaguarda da frente quente (Fig. 6d); (d) máxima intensidade do vento (entre 50 e $75 \mathrm{~m} \mathrm{~s}^{-1}$ ) em $200 \mathrm{hPa}$, configurando jatos, ocorrendo ligeiramente ao lado polar das frentes em superfície (Fig. 6c), (e) nebulosidade já adquirindo forma característica de um ciclone extratropical, isto é, padrão de vír-

\section{Pré-Ciclogênese}

a)

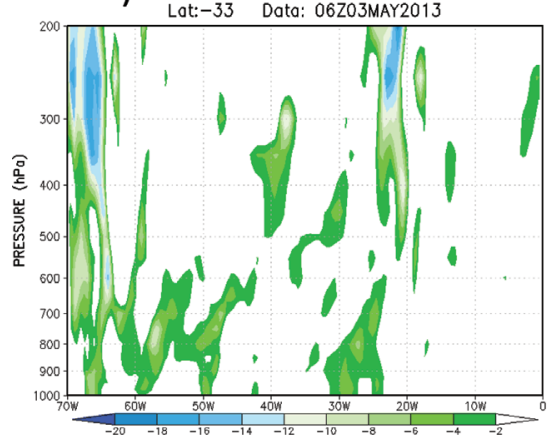

d) Lot:-33 Data: 18Z03MAY2013

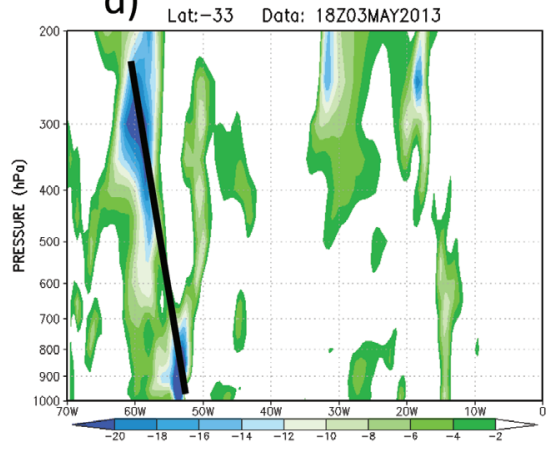

b)

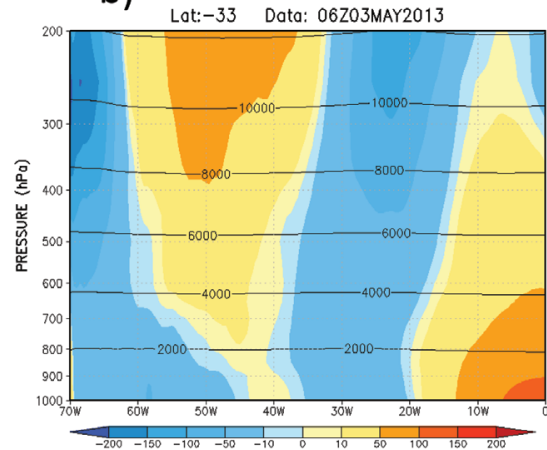

Ciclogênese

e)

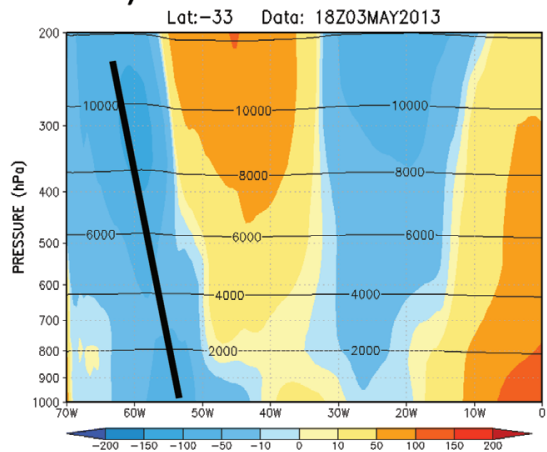

c)

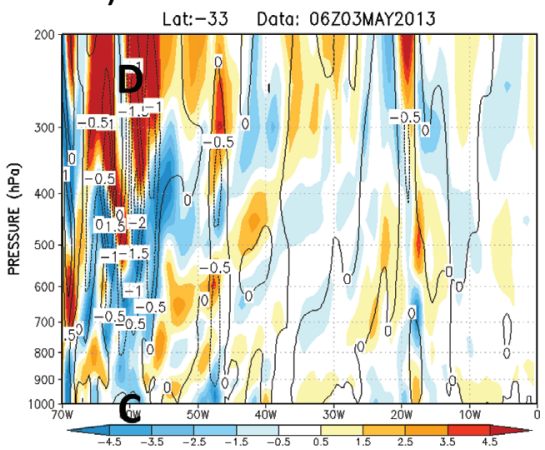

f)

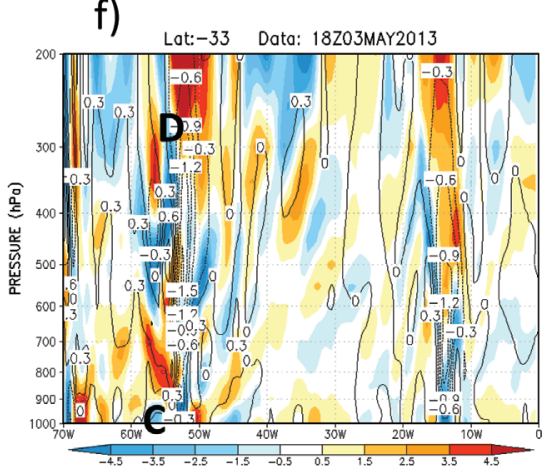

Figura 5 - Ciclo de vida do ciclone extratropical nos estágios: pré-ciclogênese (a-c), ciclogênese (d-f), maturidade (g-i) e decaimento (j-1). A coluna da esquerda apresenta um corte vertical da vorticidade relativa negativa $\left(\mathrm{s}^{-1}\right)$; a coluna central, da altura geopotencial (linha preta) e seu desvio (preenchido) em relação à média zonal (ambas em metros) e a coluna da direita, a divergência do vento ( $\times 10^{-5} \mathrm{~s}^{-1}$, preenchido) e da velocidade ômega $(\mathrm{Pa} / \mathrm{s})$. No campo da divergência, os valores positivos indicam divergência (D) enquanto os negativos, convergência (C). A letra B nas figuras indica a localização do centro de baixa pressão. 
g)

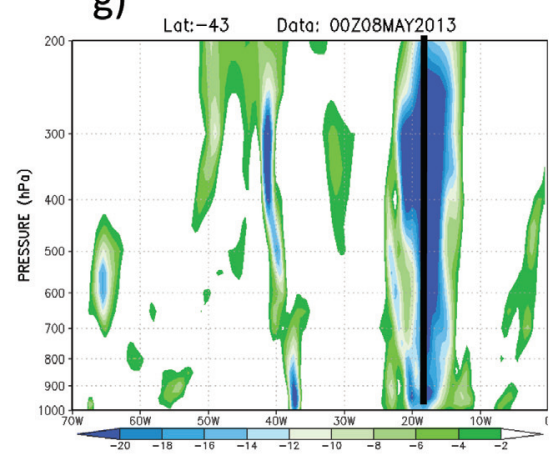

j)

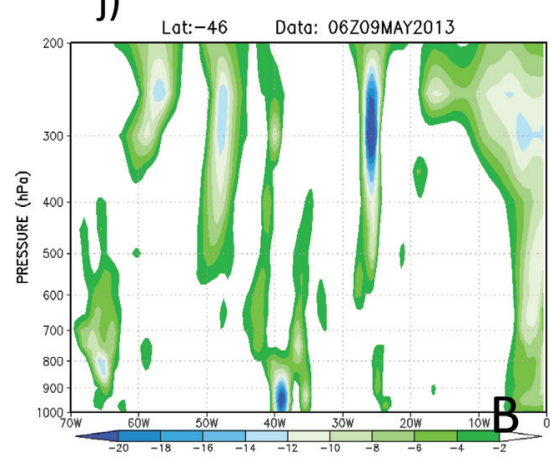

h) Maturidade

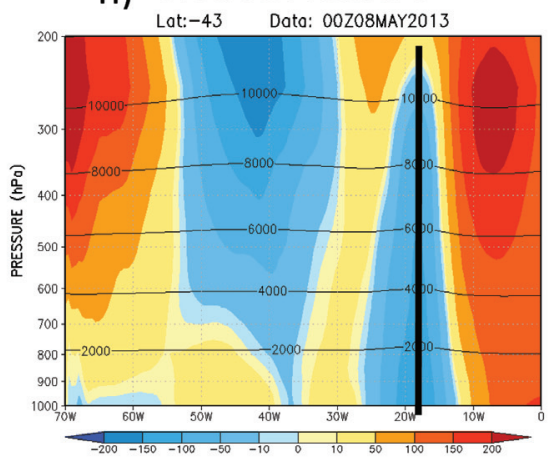

k) Decaimento

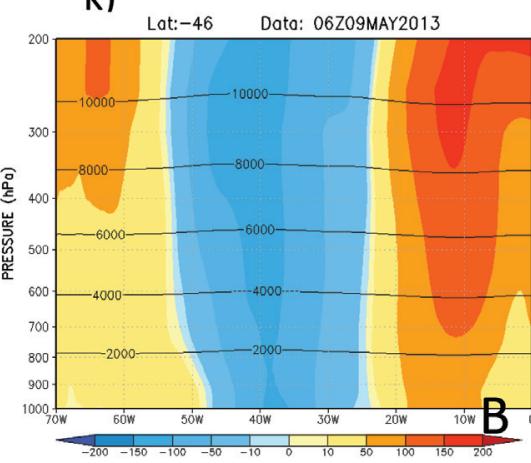

i)

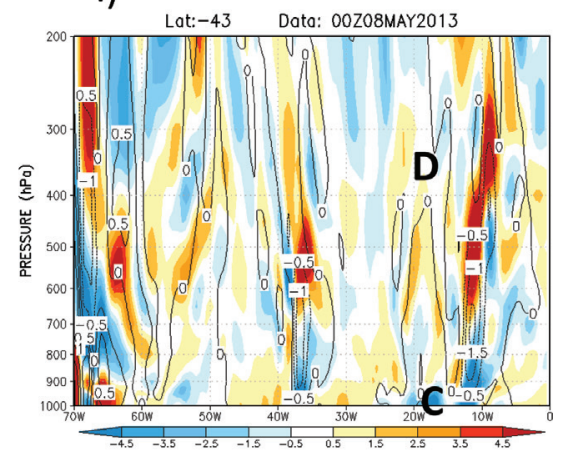

I)

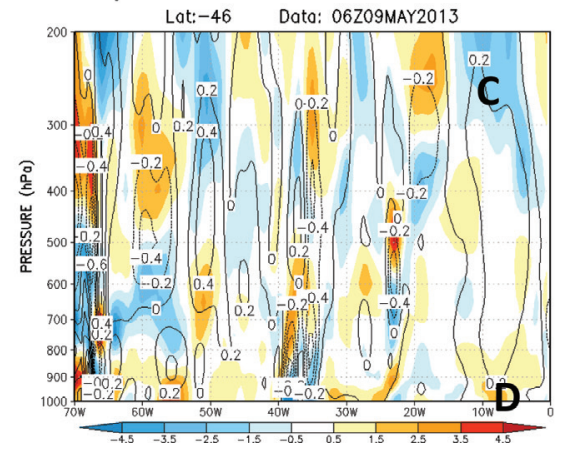

Figura 5 - Continuação.

gula invertida no Hemisfério Sul (Fig. 7d) e (f) do período pré-ciclogênese para o de ciclogênese, o cavado em $300 \mathrm{hPa}$ apresenta deslocamento para leste de forma que o setor a leste do seu eixo atua sobre a baixa em superfície (Fig. 6d) favorecendo a convergência de massa em baixos níveis pela remoção de ar em níveis mais elevados (Fig. 9f) e, portanto, o desenvolvimento do ciclone em superfície.. Outra característica do estágio de gênese é que o ciclone em superfície ocorre sob uma região de escoamento confluente em $200 \mathrm{hPa}$ (Fig. 6c), concordando com Schultz et al. (1998), quando se observa a trajetória do escoamento sobre a Argentina e Paraguai em sentido ao centro do sistema.

Com relação à temperatura do ar, as isotermas em $850 \mathrm{hPa}$ (Fig. 7c) se assemelham bastante às mostradas no modelo conceitual da Fig. 5b de Reboita et al. (2017), o que também justifica a classificação do ciclone em estudo como do tipo Shapiro e Keyser (1990). Na Fig. 8c também é mostrada a temperatura do ar, mas em 1000 hPa. Nessa, há presença de ar mais frio no setor oeste-sudoeste do ciclone e de ar mais quente nos outros setores. Assim surge uma questão: esse padrão da temperatura do ar se estende até níveis mais altos da atmosfera? O perfil vertical do desvio zonal de temperatura do ar mostra que até $300 \mathrm{hPa}$ predomina ar mais quente no setor a leste do centro do ciclone, com predomínio de movimentos ascendentes, e ar mais frio no setor a oeste do centro do sistema, com predomínio de movimentos subsidentes (Fig. 8d). Na interface das dife- rentes massas de ar (quente e fria), ocorre convergência em superfície e divergência entre 500 e $400 \mathrm{hPa}$ (Fig. 9f).

Uma vez que o ciclone em superfície e o cavado em $300 \mathrm{hPa}$ apresentam algumas semelhanças, isto é, são centros de baixos valores de altura geopotencial e com vorticidade relativa ciclônica, logo, o perfil vertical do desvio zonal de altura geopotencial indica inclinação dessa variável para oeste à medida que a altura aumenta (Fig. 9e); o mesmo ocorre com o campo da vorticidade relativa negativa (Fig. 9d).

\subsubsection{Maturidade (0600Z do dia 23/11/2014)}

A maturidade do ciclone é caracterizada por um aprofundamento do sistema, isto é, no presente estágio a pressão no centro do sistema é de $983 \mathrm{hPa}$ que é $21 \mathrm{hPa}$ menor do que no estágio de ciclogênese (1004 hPa). Além disso, a nebulosidade apresenta o padrão de vírgula invertida mais organizado (Fig. 7f) do que no estágio anterior (Fig. 7d) e com formato de espiral, se assemelhando ao modelo de Troup e Streten (1972). No estágio de maturidade, uma das características mais interessantes é a posição das frentes quente e fria ressaltando o padrão T-bone. Assim como no modelo de Shapiro e Keyser (1990), a Fig. 6f mostra um enfraquecimento do lado polar da frente fria próximo ao centro do ciclone resultando na fratura frontal (ver Fig. 5bIII do artigo de Reboita et al., 2017). Com isso, a frente quente tende a circundar o setor oeste do centro do ciclone (bent-back front, Fig. 6f), de forma que o ar mais 
frio aprisiona esse ar mais quente no centro do sistema, o que também está de acordo com o modelo conceitual. Essas características térmicas são bem visíveis no campo das isotermas em $850 \mathrm{hPa}$ (Fig. 7e), em que há um núcleo de ar quente no centro do sistema e que é cercado por ar frio, exceto no seu setor nordeste. Outra similaridade com o modelo de Shapiro e Keyser (1990) é que a frente quente é mais intensa do que a frente fria no presente estágio, o que pode ser também observado pelo enfraquecimento da advecção fria na retaguarda da frente fria (Fig. 6h). Essa última característica também foi encontrada por Gozzo e da Rocha (2013) num ciclone tipo Shapiro-Keyser ocorrido em maio de 1997 no sudoeste do oceano Atlântico Sul.

Ainda com relação à temperatura do ar no centro do ciclone, fica evidente na Fig. 8e que o sistema possui centro quente e que há uma intrusão horizontal de ar frio no lado oeste do sistema que tende a cercar a região de ar quente contribuindo para a sua seclusão. Esse mesmo padrão é observado no perfil vertical dos desvios zonais de temperatura do ar (Fig. 8f) bem como a presença de ar mais quente na região do ciclone.
Em $300 \mathrm{hPa}$, com o deslocamento do cavado para leste, o centro desse sistema se acopla com a baixa em superfície (Figs. 6 d-f), de forma que os perfis verticais de vorticidade relativa negativa (Fig. 9g) e desvio zonal de altura geopotencial (Fig. 9h) não mostram mais inclinação para oeste com o aumento da altura e sim um alinhamento vertical; com isso há um enfraquecimento da convergência em baixos níveis e divergência em níveis médios (Fig. 9i). De fato, do estágio de ciclogênese para o de maturidade há um enfraquecimento dos movimentos verticais no centro do sistema (Fig. 8f).

\subsubsection{Decaimento (0600Z do dia 24/11/2014)}

Nesse estágio, o centro do ciclone ainda possui pressão central de $983 \mathrm{hPa}$. A diferença relevante com o estágio anterior é a desconfiguração das isotermas com seclusão de ar quente e alongamento das isóbaras (Fig. 7g). Em geral, é difícil documentar o decaimento de sistemas extratropicais, uma vez que eles se propagam para latitudes mais altas e se conectam ao cinturão das baixas polares, ou aos cavados. De fato, após as $0600 \mathrm{Z}$ do dia 24/11/14 o ciclone foi embebido por um cavado (fig. não mostrada), o que impe- a)

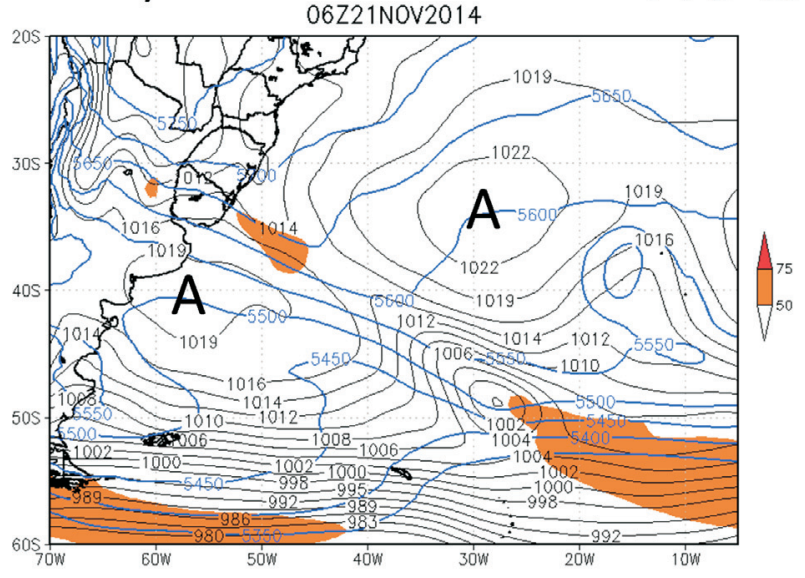

b)

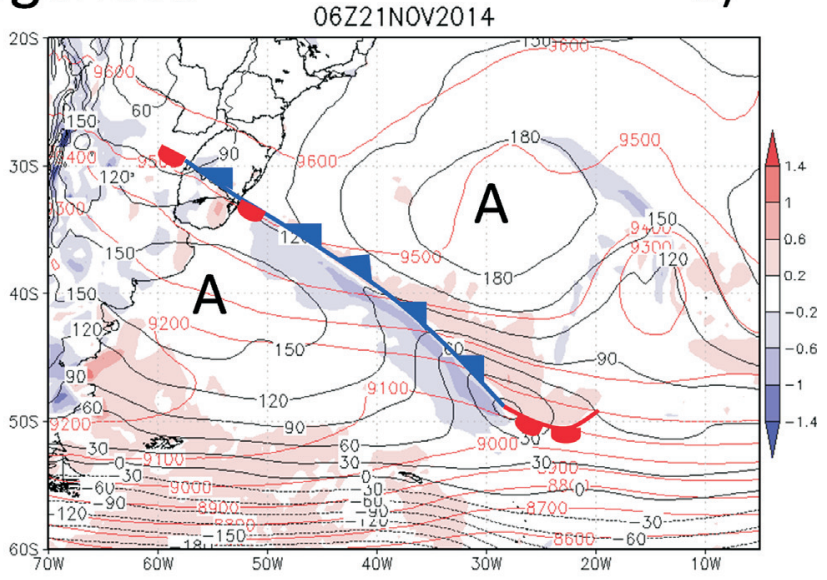

d)
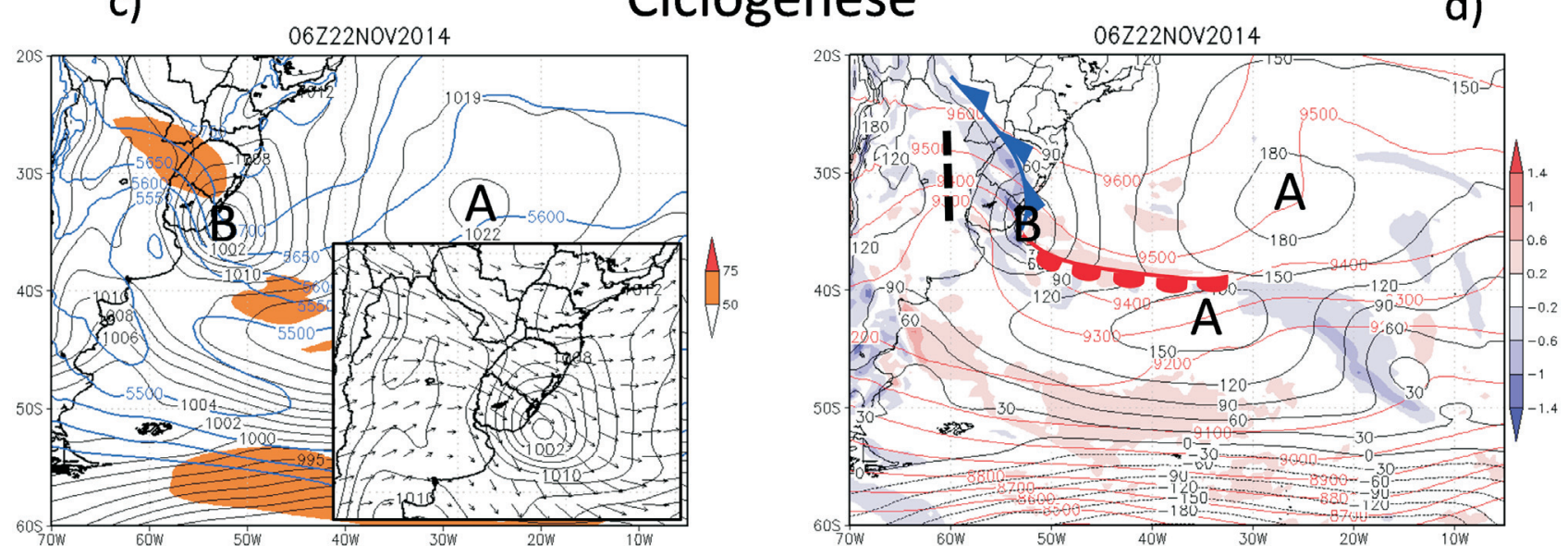

Figura 6 - Similar à Figura 2, mas para o ciclone que segue o modelo conceitual de Shapiro e Keyser. 
e)

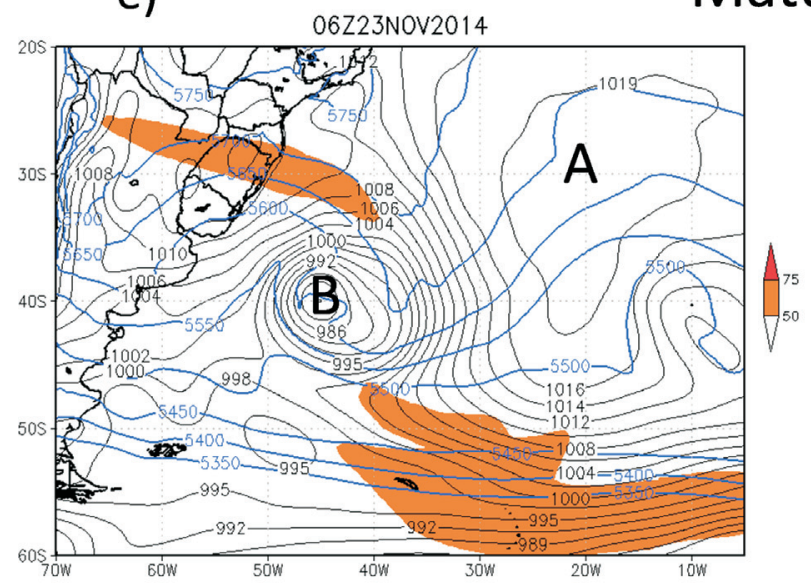

Maturidade

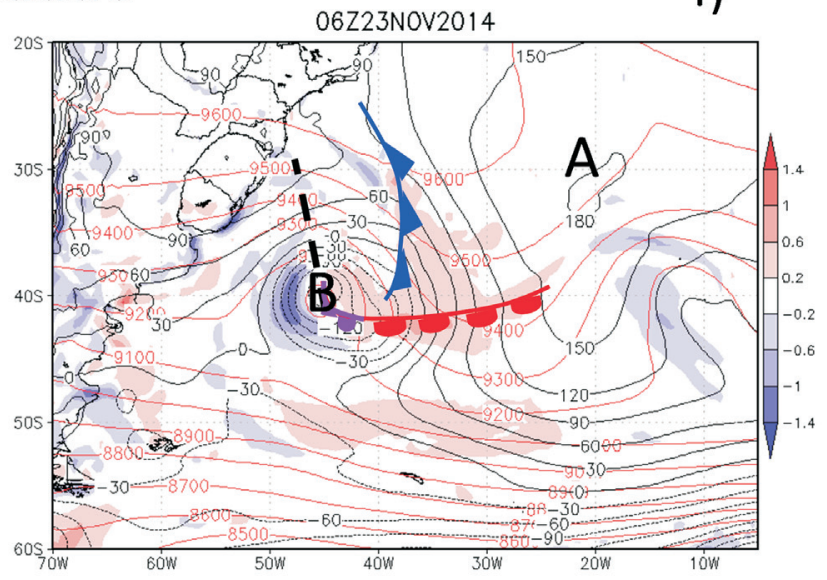

h)
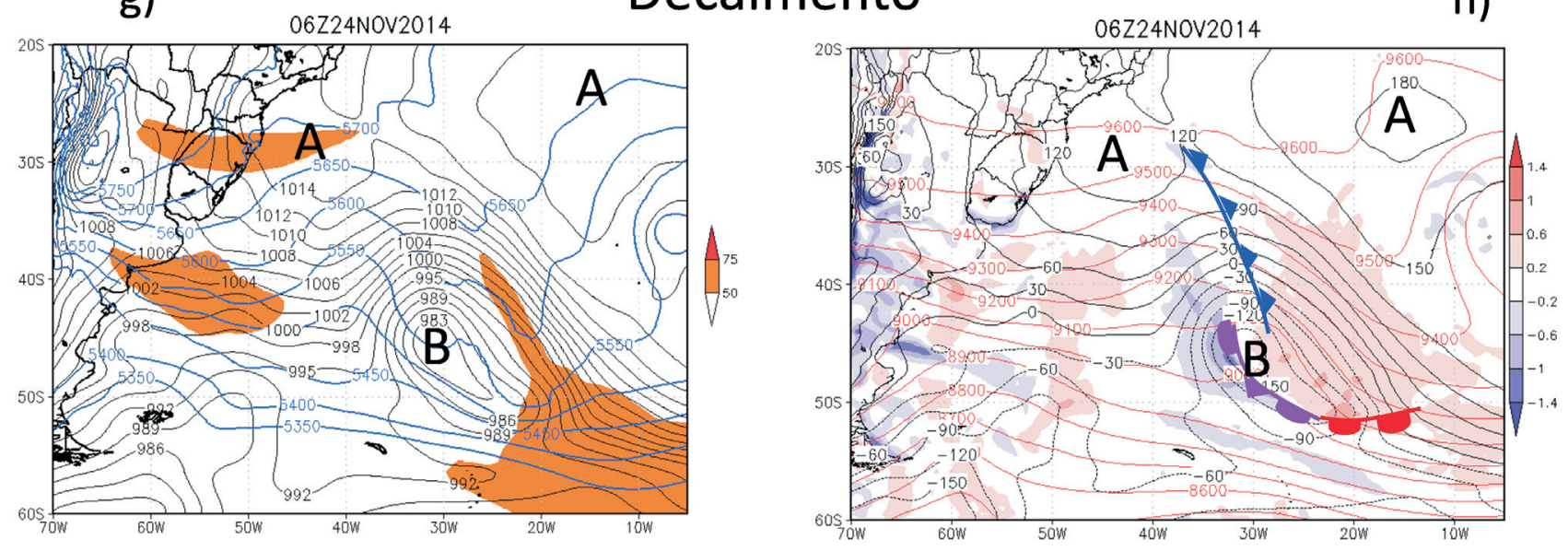

Figura 6 - Continuação.

diu a ilustração de forma mais conceitual das variáveis mostradas em perfis verticais referentes ao decaimento do sistema. Mesmo assim, ainda são identificadas características do enfraquecimento do sistema. O perfil vertical do desvio zonal de temperatura mostra que o centro do ciclone apresenta desvio zonal positivo de baixos até altos níveis da atmosfera, exceto a oeste do seu centro em que o desvio é negativo e se restringe à altura de $700 \mathrm{hPa}$. A diferença com os estágios anteriores é que nesses havia uma clara divisão entre anomalias frias e quentes com a altura, a oeste e leste do centro do ciclone, respectivamente, o que não ocorre mais no estágio de decaimento (Figs. 8b-d-f-h). É importante ter em mente que no decaimento dos ciclones extratropicais, o resfriamento ocorre de baixos para níveis mais elevados. A Fig. $8 \mathrm{~h}$ sugere que o ar frio irá dominar o centro do ciclone em baixos níveis da atmosfera.

No decaimento dos ciclones extratropicais espera-se que o tubo de vorticidade relativa ciclônica e de desvios negativos de altura geopotencial não se inclinem ou se inclinem para leste com o aumento da altitude. Entretanto, no caso estudado, a inclinação para leste não ocorre perfeitamente, pois como o cavado em $300 \mathrm{hPa}$ somente perdeu amplitude e não teve um deslocamento apreciável para leste (Fig. 6h), a anomalia zonal de altura geopotencial negativa se restringe até cerca de $400 \mathrm{hPa}$ (evidenciando o enfraquecimento do cavado) sem mostrar inclinação para leste, enquanto que a vorticidade relativa negativa mostra um enfraquecimento em todo o perfil vertical analisado, o que indica o enfraquecimento tanto do ciclone em superfície (embora o campo de pressão atmosférica tenha mostrado mínimo similar ao do estágio de maturidade) como do cavado em $300 \mathrm{hPa}$. É interessante destacar que em baixos níveis da atmosfera (até cerca de $600 \mathrm{hPa}$ ), a vorticidade relativa negativa tem uma inclinação para oeste e, a partir de $600 \mathrm{hPa}$, mostra um perfil ligeiramente inclinado para leste (que é associado ainda à vorticidade do centro do cavado enfraquecido). Finalizando, tem-se que o ciclone analisado mostra um perfil alongado das isóbaras em superfíice no sentido da frente quente (Figs. $6 \mathrm{~h} \mathrm{e} 8 \mathrm{~g}$ ) concordando com o estágio IV (Fig. 5bIV de Reboita et al., 2017) do modelo conceitual de Shapiro e Keyser (1990). 


\subsection{Ciclone tropical}

Nessa seção, as características sinóticas do ciclo de vida do ciclone tropical Ului são analisadas. Esse ciclone teve gênese sobre o oceano, a nordeste da Austrália, e decaiu ao atingir esse continente.

\subsubsection{Pré-ciclogênese (0000Z do dia 10/03/2010)}

O ambiente que permitirá a gênese do ciclone tropical é caracterizado por fluxos de calor total (calor sensível + calor latente) da superfície oceânica para a atmosfera variando entre 100 e $200 \mathrm{~W} \mathrm{~m}^{-2}$ (fig. não mostrada), TSM de $29^{\circ} \mathrm{C}$, que para a época do ano e região analisada é anomalamente quente em cerca de $1,5^{\circ} \mathrm{C}$ (Fig. 10a), por fraco cisalhamento vertical do vento (variando de -5 a $5 \mathrm{~m} \mathrm{~s}^{-1}$ ) entre as superfícies 925 e $200 \mathrm{hPa}$ (Fig. 10b) e fraca vorticidade relativa ciclônica em baixos níveis da atmosfera na região em que o ciclone se forma (Fig. 13a). Todas essas características são condições necessárias para a ciclogênese tropical (Gray, 1968). Além disso, os valores obtidos de cisalhamento vertical concordam com o do estudo climatológico de Paterson et al. (2005) que indicam valores menores de $10 \mathrm{~m} \mathrm{~s}^{-1}$ favoráveis a intensificação de ciclones tropicais ao redor da Austrália. Com relação aos mecanismos favoráveis à gênese dos ciclones tropicais ao redor de tal continente, Dare e Davidson (2004) sugerem que o máximo de vorticidade relativa ciclônica em baixos níveis coincide com o cavado de monção de dezembro a fevereiro e no lado polar desse nos outros meses.

No caso do ciclone Ului, sugere-se que o ambiente dinâmico favorável a sua gênese foi um cavado formado no escoamento de oeste em $700 \mathrm{hPa}$ (Fig. $10 \mathrm{c}$-d), que induziu circulação ciclônica e, consequentemente, vorticidade relativa ciclônica e convergência em baixos níveis da atmosfera (Fig. 13 b-c). A junção dessas características também é revelada através da nebulosidade com forma assimétrica na imagem de satélite (Fig. 11a).

No campo da pressão ao nível médio do mar, nesse estágio pré-ciclogênese, já é evidente uma isóbara fechada com valor de $1008 \mathrm{hPa}$ (Fig. 11b), mas no campo da altura geopotencial em $1000 \mathrm{hPa}$, ainda não há linhas fechadas caracterizando o sistema (Fig. 11c). No perfil vertical do desvio zonal de temperatura do ar predominam desvios a)

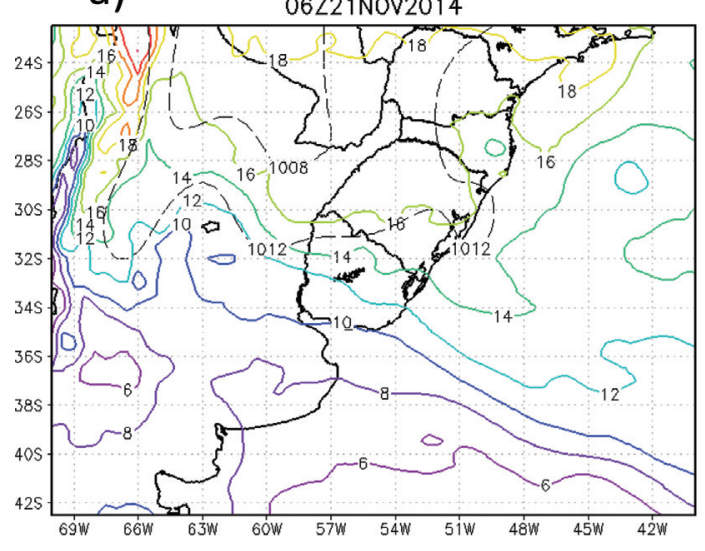

\section{Pré-Ciclogênese}
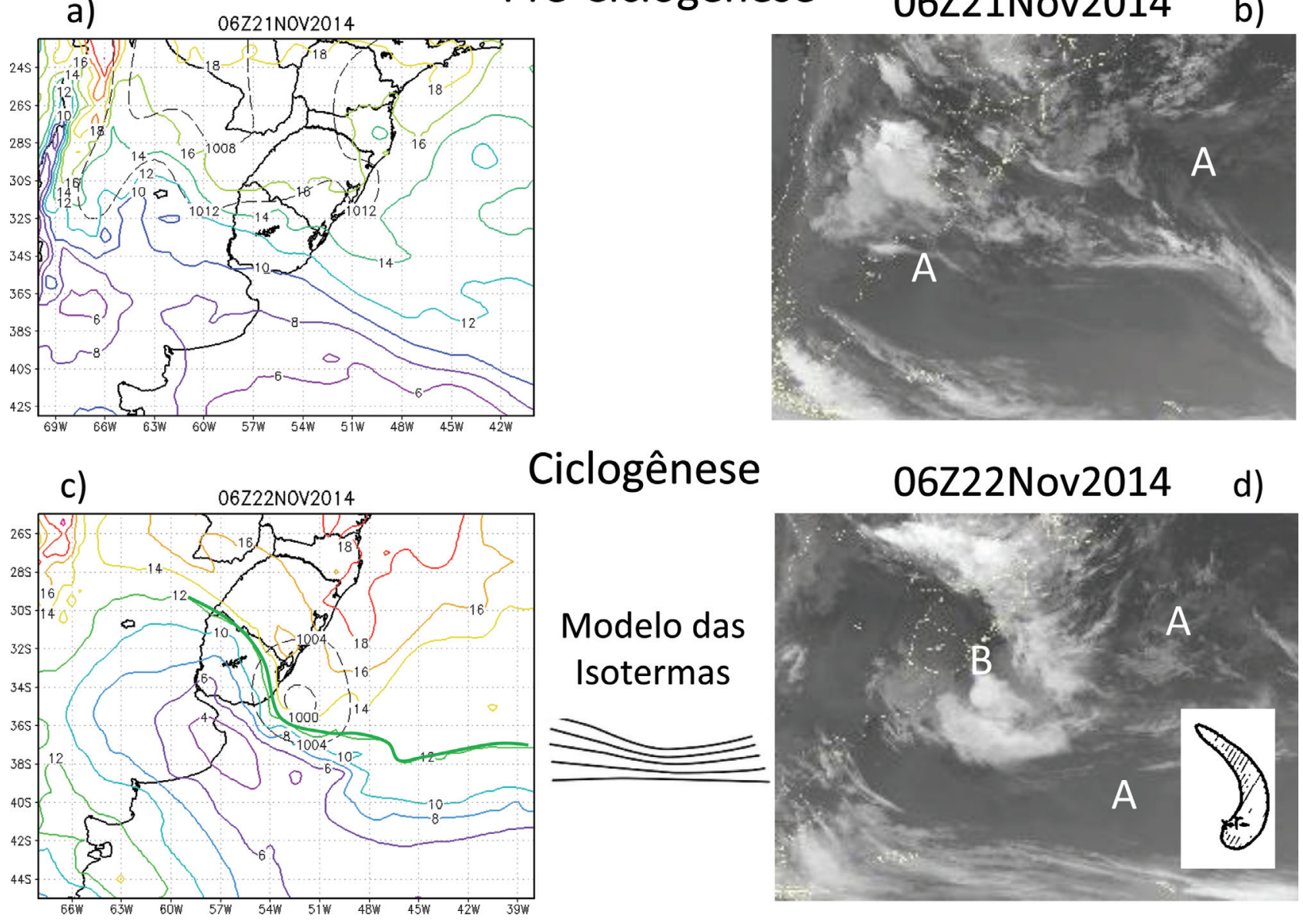

Figura 7 - Similar à Figura 3, mas para o ciclone que segue o modelo conceitual de Shapiro e Keyser (1990). Na coluna da direita, tem-se imagens do satélite GOES-13 no canal infravermelho. Também são apresentados os modelos conceituais das isotermas do ciclone tipo Shapiro e Keyser e do padrão da nebulosidade em ciclones extratropicais observado em imagens de satélite, seguindo Troup e Streten (1972). 


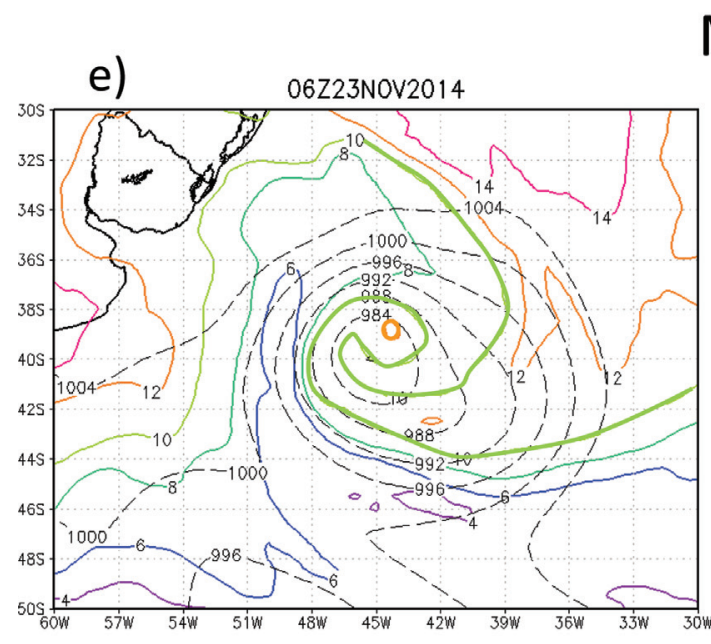

Maturidade
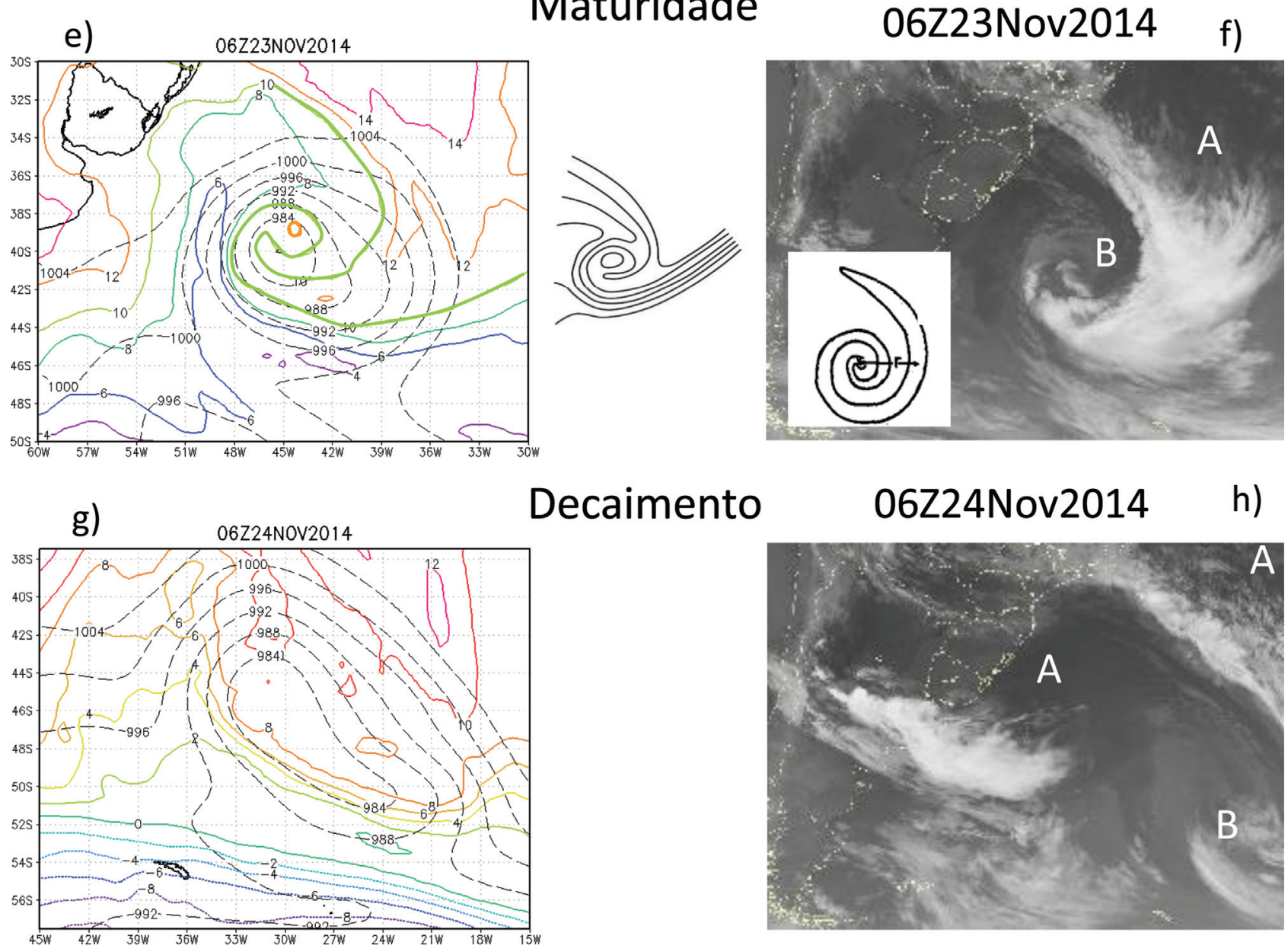

Decaimento

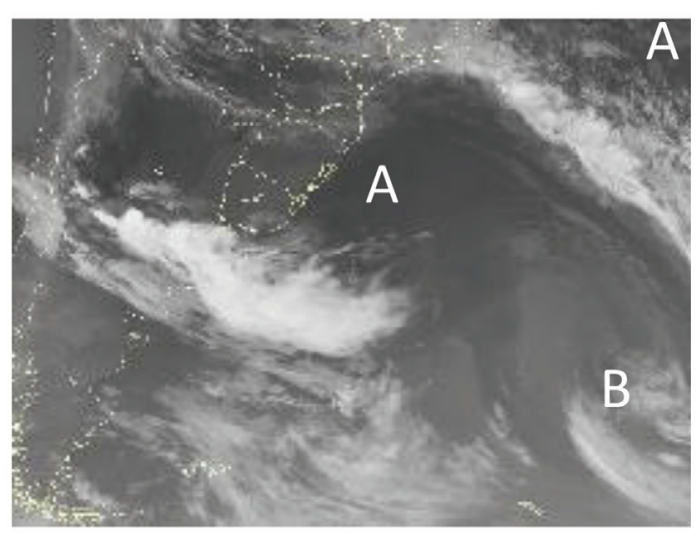

Figura 7 - Continuação.

negativos em baixos níveis (até $\sim 900 \mathrm{hPa}$ ). Isso ocorre associado ao seguinte processo: inicialmente a convergência dos ventos em baixos níveis favorece a transferência de energia (calor latente e sensível) do mar para a atmosfera adjacente; por outro lado, como a energia é removida da superfície do mar, essa se torna mais fria do que as camadas de ar ligeiramente acima e o ar acaba cedendo calor para o mar, logo há resfriamento da camada de ar adjacente ao mar. Outro processo que pode contribuir para os desvios negativos de temperatura do ar em baixos níveis é a evaporação do spray oceânico e da precipitação Estudos como o de Hawkins e Rubsan (1968), Hawkins e Imbembo (1976) e Kidder et al. (2000) também relatam a ocorrência de desvios negativos de temperatura do ar em baixos níveis nos ciclones tropicais. Diferentemente do ambiente pré-ciclone extratropical, no do tropical não há gradientes horizontais de temperatura do ar (Fig. 12a) e nem advecção horizontal de temperatura em superfície (Fig. 11c).

\subsubsection{Ciclogênese (0000Z do dia 12/03/2010)}

Uma vez que as condições ambientais necessárias para a ciclogênese se mantiveram do estágio pré-ciclogêne- se até o atual, o distúrbio pré-existente pode se organizar num ciclone tropical. Conforme descrito em COMET (2015), as águas oceânicas quentes são a fonte de energia para os ciclones tropicais através da evaporação (fluxo de calor latente) e da transferência de calor (fluxo de calor sensível) para a camada limite atmosférica. Esses fluxos e a energia potencial formam a energia estática úmida do ar. Já a conversão da energia estática úmida em energia cinética, através de convecção, é o mecanismo que intensifica os ciclones tropicais. As características de ciclone tropical são evidentes em todos os campos atmosféricos analisados (Figs. 11, 12 e 13). A imagem de satélite no canal infravermelho (Fig. 11d) indica, com as cores tendendo do vermelho ao amarelo, que há mais nuvens com topos frios no estágio de ciclogênese e também que a nebulosidade assumiu um padrão simétrico. A simetria do ciclone é bem visível no campo de pressão ao nível médio do mar (agora com núcleo possuindo $1006 \mathrm{hPa}$, Fig. 11e). Do estágio pré-ciclogênese para o atual, a área de ocorrência das anomalias frias em superfície diminui (Fig. 12d), os movimentos ascendentes se intensificam (indo da superfície até o topo da figura que é $200 \mathrm{hPa}$, Figs. 12d e 13f), o tubo de 
vorticidade relativa torna-se mais definido verticalmente (Fig. 13d) e a área de convergência em superfície se expande (Fig. 13f). Os fluxos de calor total do oceano para atmosfera, na região do ciclone, mantêm-se em torno de $200 \mathrm{~W} \mathrm{~m}^{-2}$ (fig. não mostrada).

Com relação à estrutura vertical da temperatura dos ciclones tropicais (Fig. 12d), Emanuel (1998) menciona que atemperatura do olho desses sistemas pode ser de $2{ }^{\circ} \mathrm{C} \mathrm{a}$ $20^{\circ} \mathrm{C}$ mais quente do que o ambiente ao seu redor. A maior parte dessa diferença de temperatura é encontrada próxima do topo da tempestade; já o ar na superfície pode não apresentar desvios zonais de temperatura ou até valores negativos, o que é devido aos ventos fortes que propiciam à ocorrência da evaporação tanto do spray oceânico quanto da própria precipitação. Hawkins e Rubsam (1968), Hawkins e Imbembo (1976) e Kidder et al. (2000) também documentam essa característica fria na base de alguns ciclones tropicais. Já o fato do maior aquecimento no olho do ciclone tropical ser encontrado próximo ao topo da tem- pestade é consequência do aquecimento da atmosfera por liberação de calor latente no processo de condensação (Kidder et al., 2000).

\subsubsection{Maturidade (0000Z do dia 16/03/2010)}

Uma vez ocorrida a gênese do ciclone tropical, o sistema se torna autossuficiente, pois a presença do núcleo de baixa pressão induz a convergência dos ventos para tal região que vão se tornando mais intensos e favorecendo uma maior transferência de fluxos de calor total do oceano para a atmosfera (há um mecanismo de feedback positivo; ou como menciona Emanuel (1986): "self-induced heat transferer from the ocean"). De fato, no presente estágio, os fluxos de calor total excedem a $700 \mathrm{~W} \mathrm{~m}^{-2}$ na região do ciclone (fig. não mostrada). Às $0000 Z$ do dia 16/03/2014 foi escolhida como estágio de maturidade devido ao ciclone apresentar um olho bem definido no campo de nebulosidade (Fig. 11g), um grande aprofundamento de pressão central (940 hPa, Fig. 11h), maiores valores de desvio zonal a)

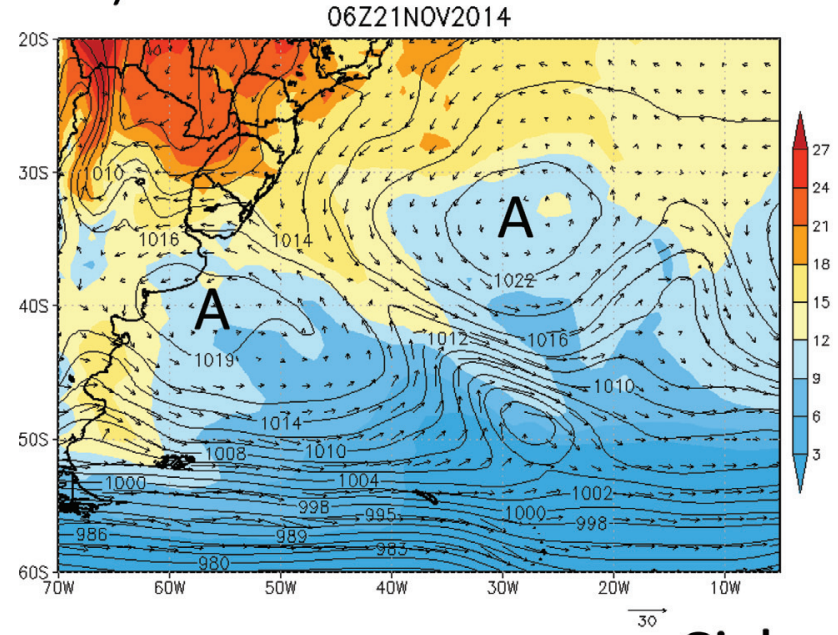

\section{Pré-Ciclogênese}

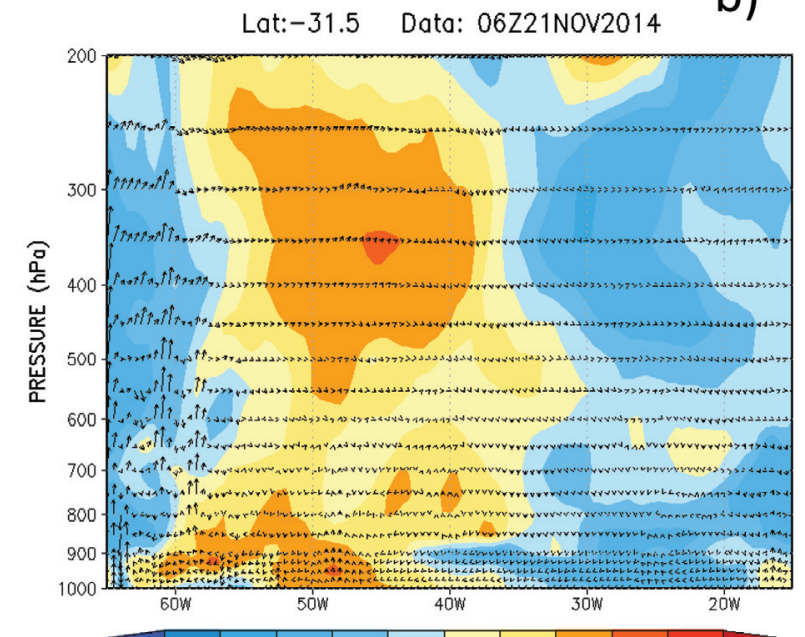

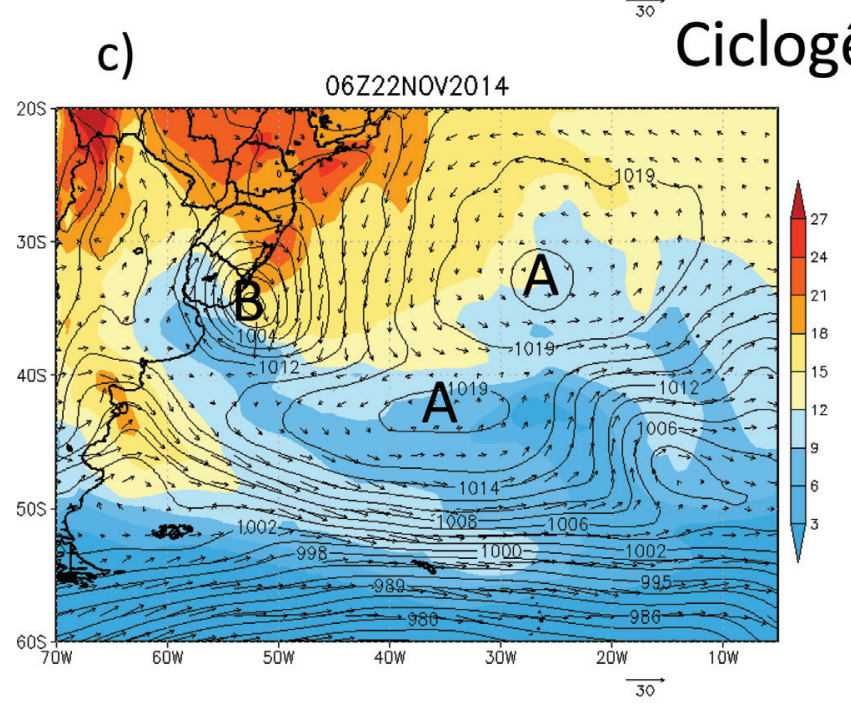

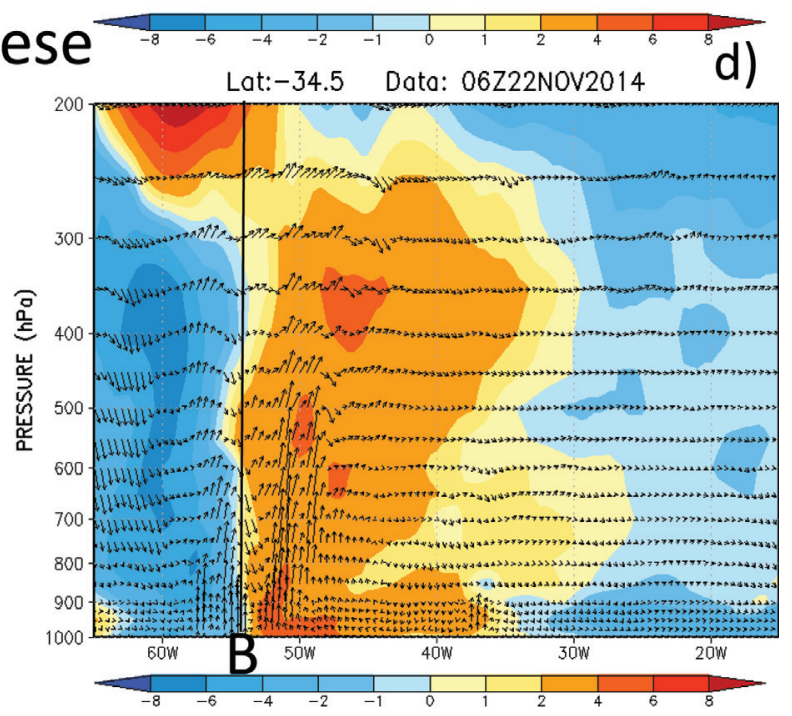

Figura 8 - Similar à Figura 4, mas para o ciclone que segue o modelo conceitual de Shapiro e Keyser (1990). 

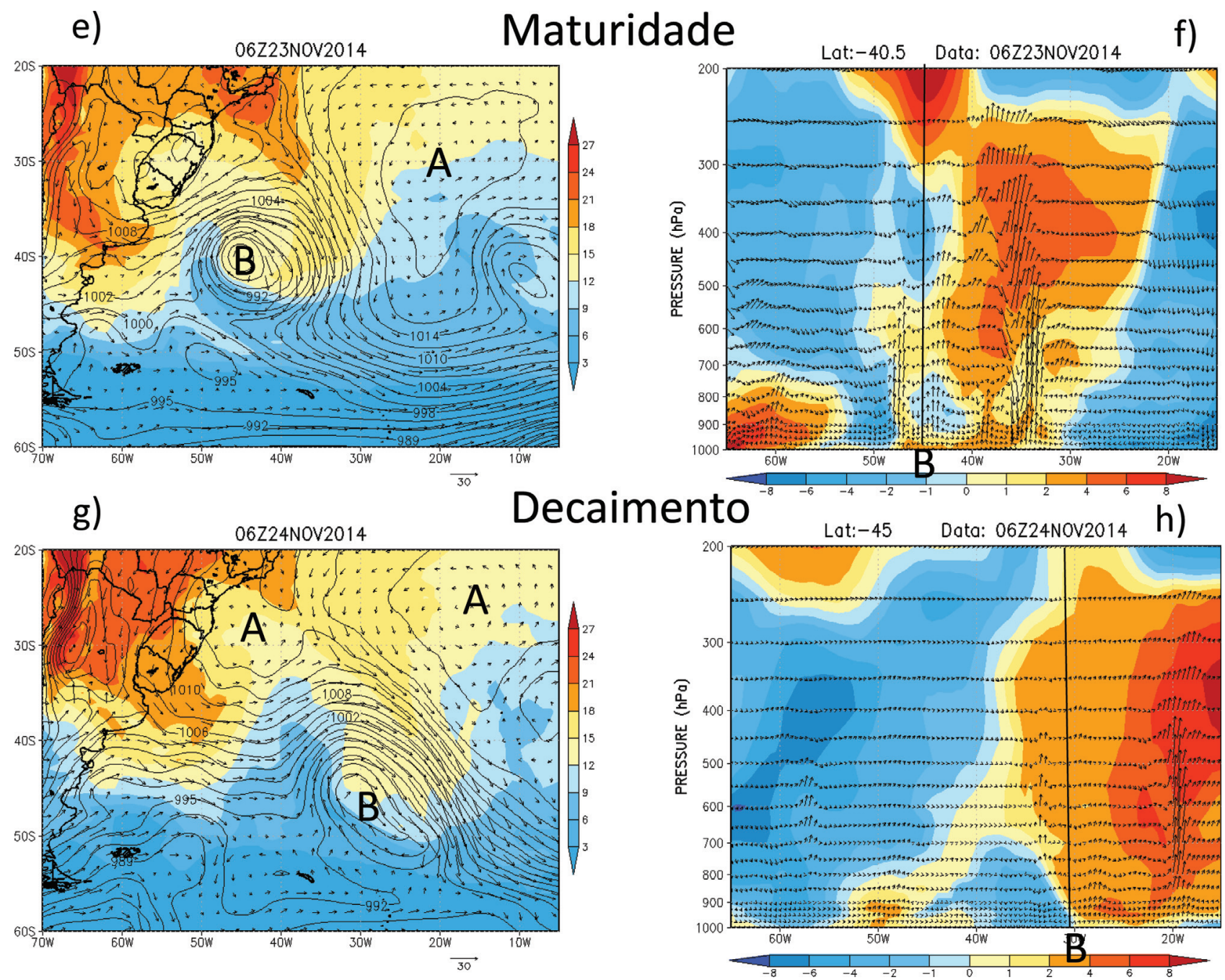

Figura 8 - Continuação.

da temperatura do ar em praticamente toda a coluna atmosférica (Fig. 12f), vorticidade relativa ciclônica mais intensa (Fig. 13g), maior desvio zonal negativo de altura geopotencial (Fig. 13h) e intensa convergência de massa em baixos níveis e divergência em altos níveis (Fig. 13i). Nesse mesmo dia, o Australia Severe Weather classificou o ciclone tropical como ciclone de categoria 4 (que na bacia do oceano Atlântico seria chamado de furacão), uma vez que o sistema às $0000 \mathrm{Z}$ do dia 16/03/2014 possuía ventos com intensidade de cerca de $185 \mathrm{~km} \mathrm{~h}^{-1}\left(51,4 \mathrm{~m} \mathrm{~s}^{-1}\right)$.

Quatro características que merecem destaque nesse estágio do ciclone tropical são: (1) os maiores desvios zonais de temperatura do ar ocorrem na alta troposfera, enquanto que desvios positivos fracos ocorrem próximo à superfície. Esses fracos desvios em baixos níveis podem ser justificados devido à camada atmosférica, da base do ciclone tropical, estar perto do oceano que utiliza energia da atmosfera para a evaporação e também devido à atmosfera se resfriar pela evaporação da precipitação, características que concordam com Kidder et al. (2000); (2) os movi-

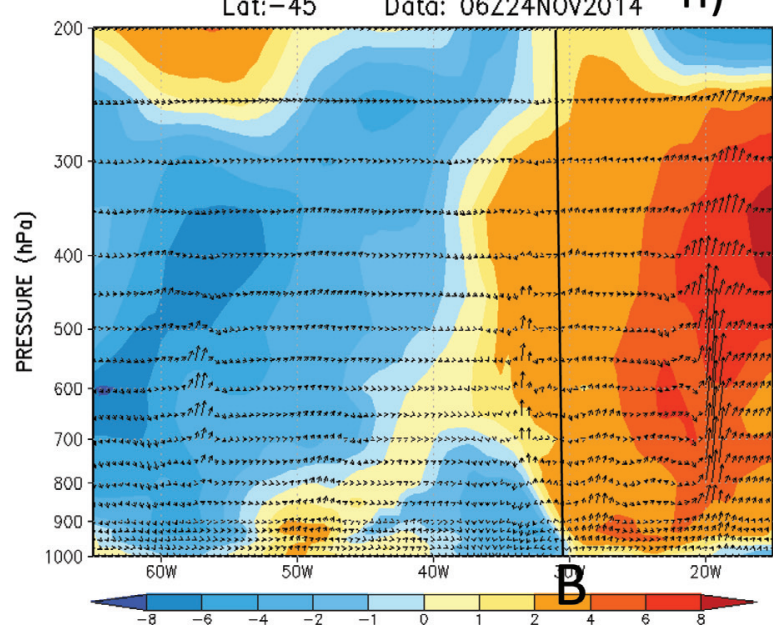

mentos ascendentes ocorrem ao redor do núcleo quente enquanto que na periferia e no setor central (olho) do ciclone há movimentos descendentes. Esses movimentos no olho do ciclone são importantes para ocorrência de "tempo bom" em tal região, mas eles não contribuem para aumento de pressão em superfície; (3) as linhas de altura geopotencial sofrem uma perturbação em direção aos níveis mais altos. Esse fato está associado com o grande transporte de ar quente na vertical que acaba "empurrando" as superfícies de mesma altura geopotencial para cima e (4) intensa convergência de massa na região do ciclone em baixos níveis e divergência acima dessa na alta troposfera e cercada por convergência.

\subsubsection{Decaimento (0000Z do dia 21/03/2010)}

Após o estágio de maturidade, o ciclone se desloca para oeste até que às $0000 \mathrm{Z}$ do dia 21/03/2010 atinge o setor continental do nordeste da Austrália (Fig. 11 j-1). A partir desse instante, o ciclone começa a se dissipar por duas causas principais: redução da energia fornecida pelo 
a) Lat: -31.5 Data: 06z21NOV2014

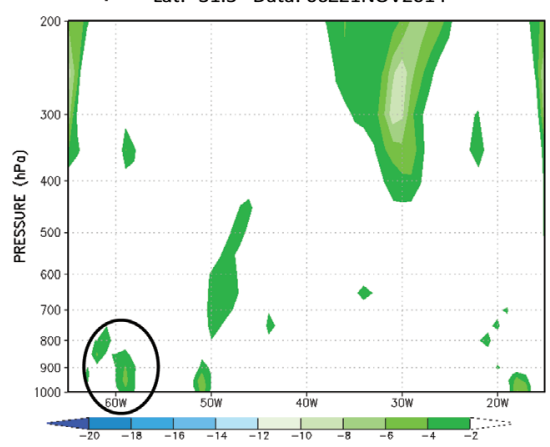

d)

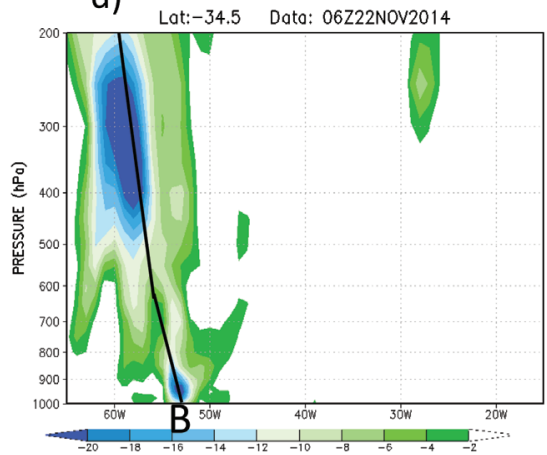

g)
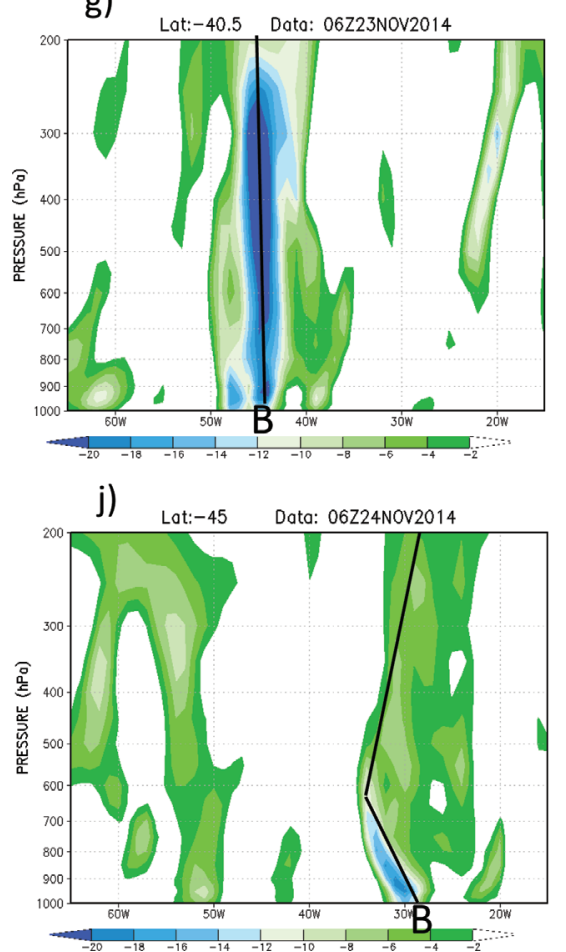

Pré-Ciclogênese

b) Lat:-31.5 Data: 06z21Nov2014

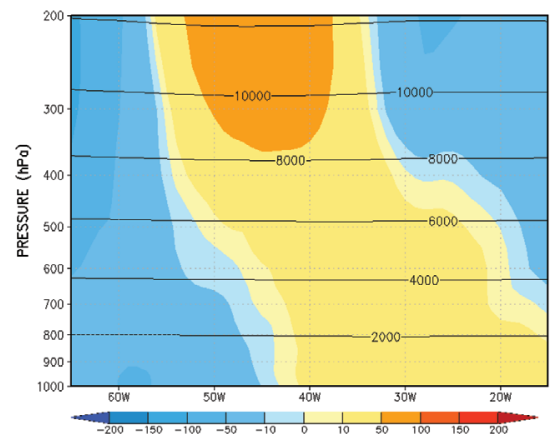

e) Ciclogênese

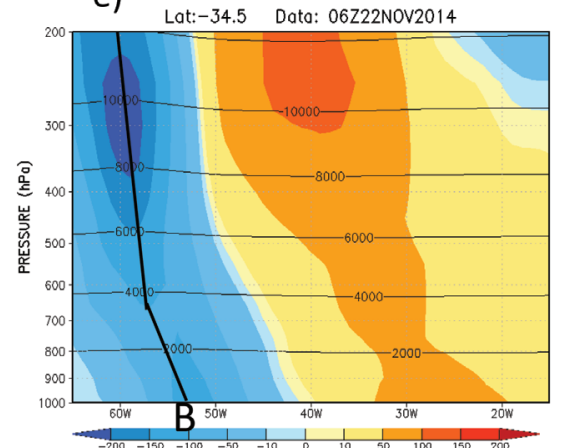

h) Maturidade

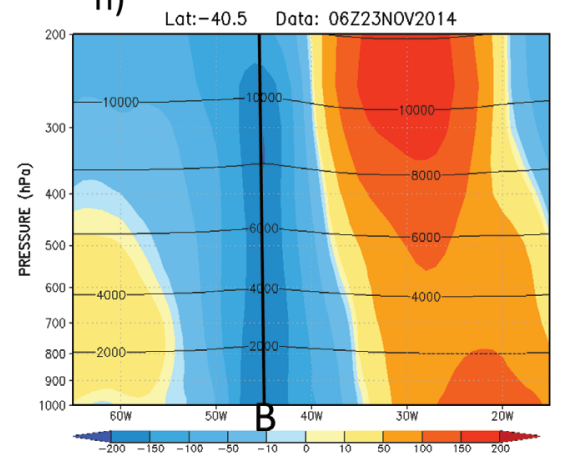

k) Decaimento

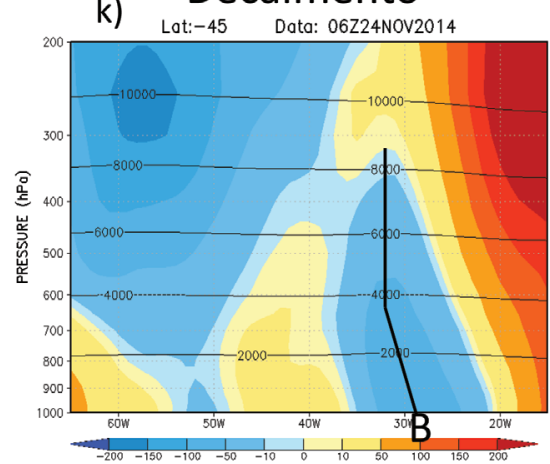

C) Lat:-31.5 Data: 06z21Nov2014

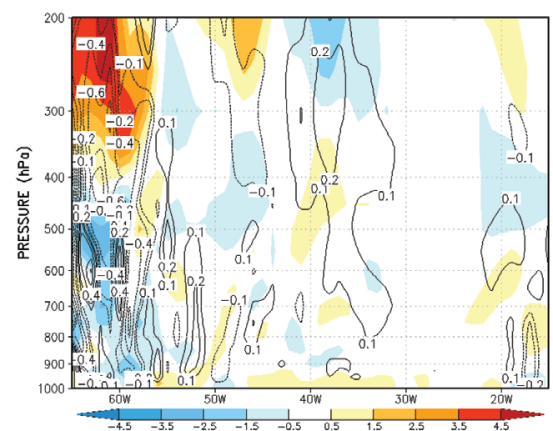

f)

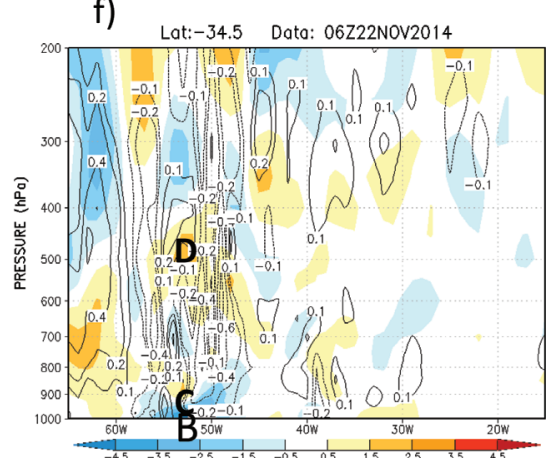

i)

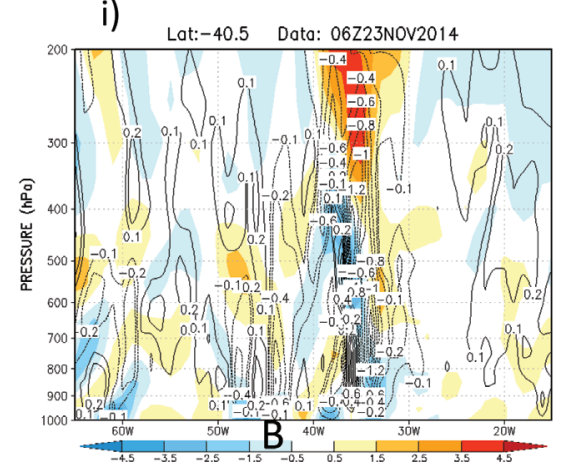

l)

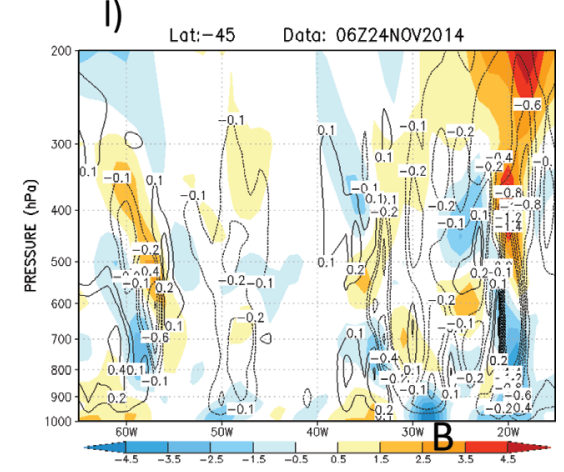

Figura 9 - Similar à Figura 5, mas para o ciclone que segue o modelo conceitual de Shapiro e Keyser (1990).

oceano e aumento da fricção sobre o continente. A falta da fonte de umidade enfraquece a convecção e isso, por sua vez, enfraquece o núcleo quente do ciclone na troposfera superior e, assim, a pressão no centro do ciclone em super- fície começa a aumentar passando para $1006 \mathrm{hPa}$ (Fig. 11k). Já o efeito de fricção, associado à maior rugosidade da superfície continental (topografia, construções, diferentes tipos de vegetação etc.), atua no sentido de enfra- 


\section{a) $07-13$ MAR2010}

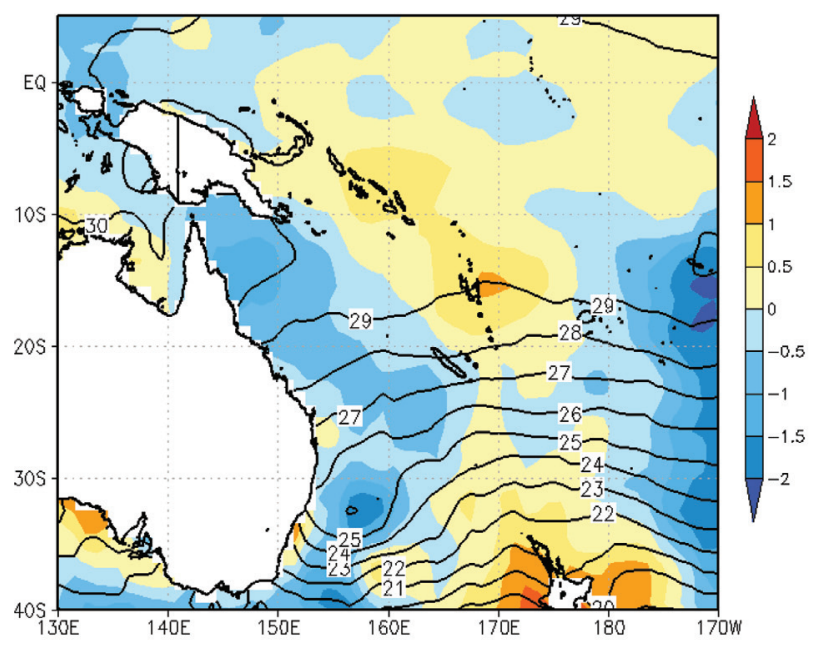

\section{C) Vento $700 \mathrm{hPa}$ - Data: 00Z09MAR2010}

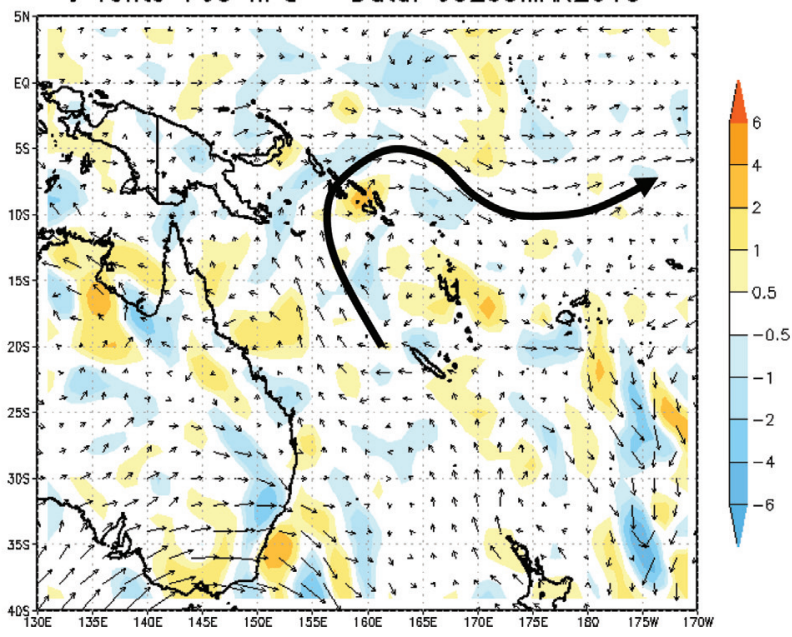

b)
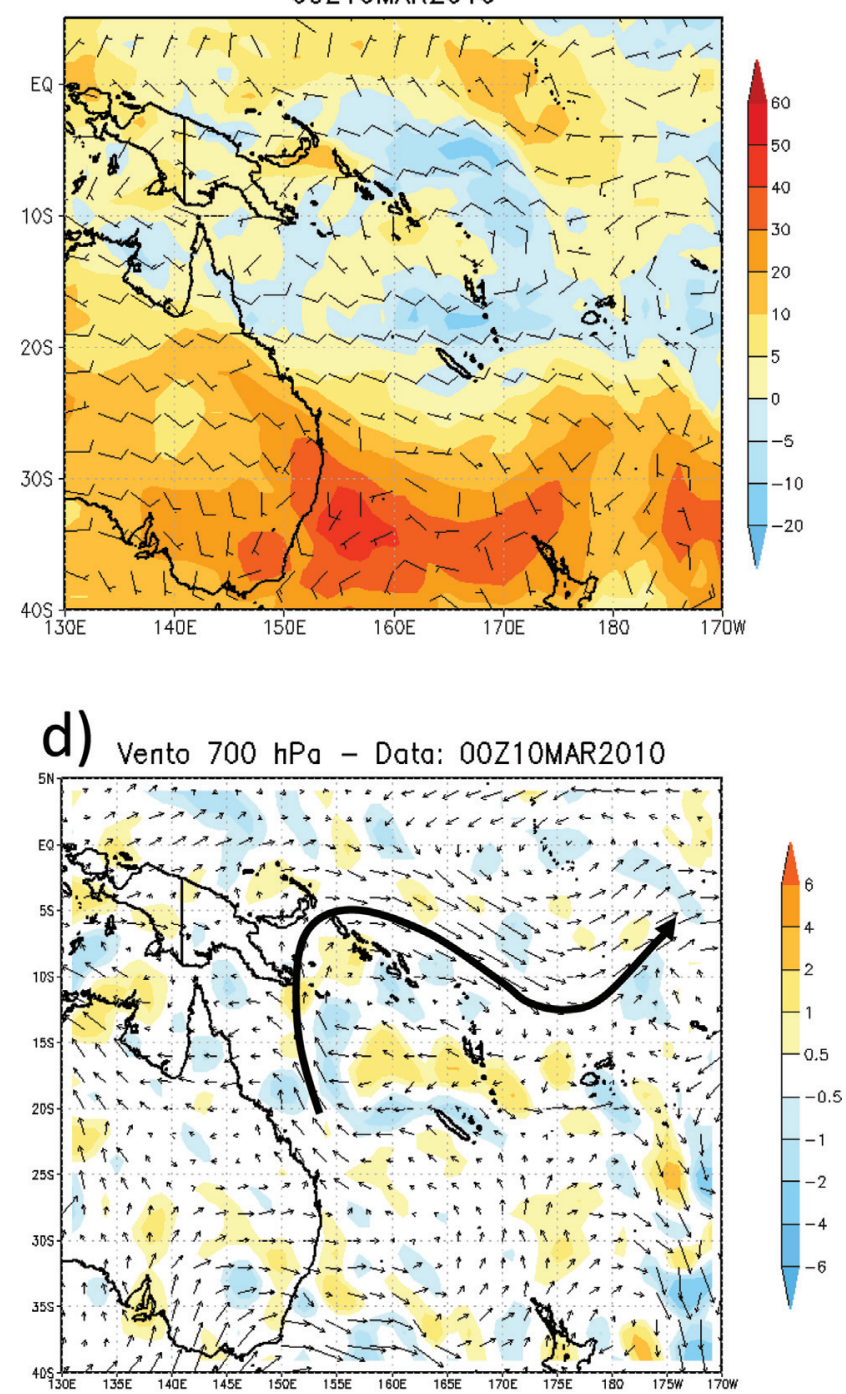

Figura 10 - Ambiente pré-ciclogênese: a) temperatura da superfície do mar $\left({ }^{\circ} \mathrm{C}\right.$, linha preta) e anomalia semanal (07 a 13 de março de 2010, preenchido), b) cisalhamento vertical do vento entre 200 e $925 \mathrm{hPa}\left(\mathrm{m} \mathrm{s}^{-1}\right.$, preenchido) e barbelas da intensidade e direção do vento em $925 \mathrm{hPa}$ às $0000 \mathrm{Z}$ do dia 10 de março de $2010, \mathrm{c}$ ) vetores da direção do vento (setas) e divergência de massa $\left(10^{-5} \mathrm{~s}^{-1}\right.$, colorido) às $0000 \mathrm{Z}$ do dia 09 de março e d) vetores da direção do vento (setas) e divergência de massa $\left(10^{-5} \mathrm{~s}^{-1}\right.$, colorido) às $0000 \mathrm{Z}$ do dia 10 . Em c-d, a linha preta indica a localização de um cavado.

quecer os ventos em superfície. Neste estágio, o ciclone apresenta nebulosidade sobre o continente com padrão menos simétrico e mais enfraquecida (Fig. 11j) do que na maturidade. Agora, os movimentos subsidentes no centro do ciclone são substituídos por ascendentes na região de desvio zonal positivo de temperatura do ar na média e alta troposfera (Fig. 12h). Já em níveis mais baixos (até $600 \mathrm{hPa}$ ), predominam desvios negativos de temperatura do ar (Fig. 12h). O decaimento do ciclone também é nítido através do enfraquecimento da vorticidade relativa ciclônica (Fig. 13j) e do desvio zonal negativo de altura geopotencial (Fig. 13k) quando comparados aos estágios anteriores.

\subsection{Ciclone subtropical}

O ciclone analisado nessa seção, denominado de Arani, é um típico ciclone subtropical no sudoeste do oceano Atlântico Sul, uma vez que desde a gênese apresenta estrutura térmica híbrida: é quente em baixos níveis como os ciclones tropicais e frio em níveis médios/altos como os extratropicais. Além disso, o sistema não transiciona ao longo do ciclone de vida.

\subsubsection{Pré-ciclogênese (1200Z do dia 13/03/2011)}

$\mathrm{O}$ ambiente prévio à gênese do ciclone mostra uma banda de nebulosidade estendida da região sudeste do Brasil ao oceano Atlântico Sudoeste e com máxima intensidade entre as costas dos Estados do Rio de Janeiro e Espírito Santo (Fig. 14a), coincidindo com o setor leste de um 


\section{Pré-Ciclogênese}

a)

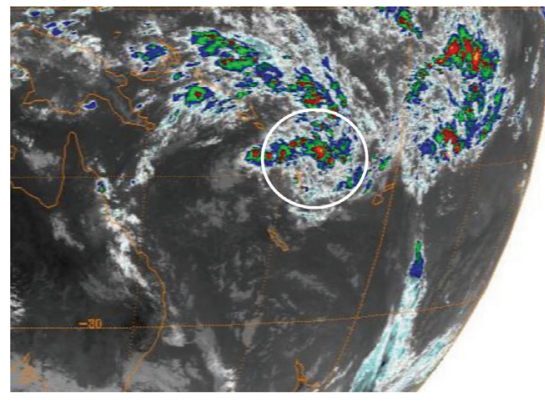

d)

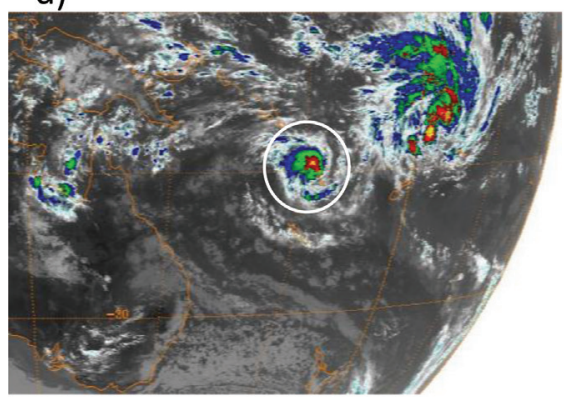

b)

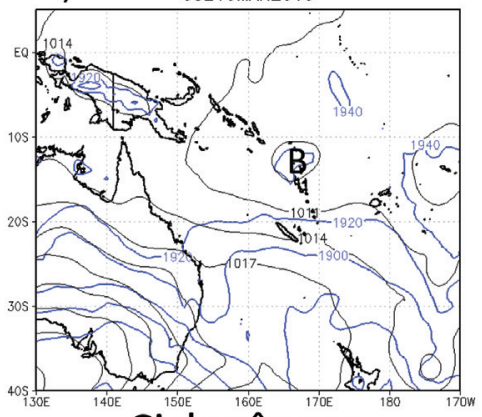

Ciclogênese

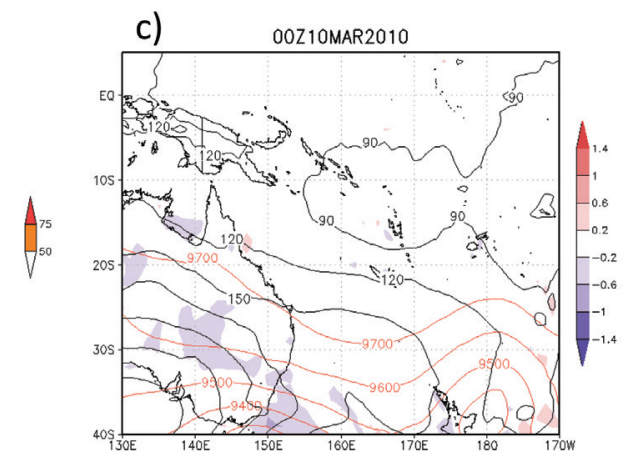

e)

DOZ12MAR2010
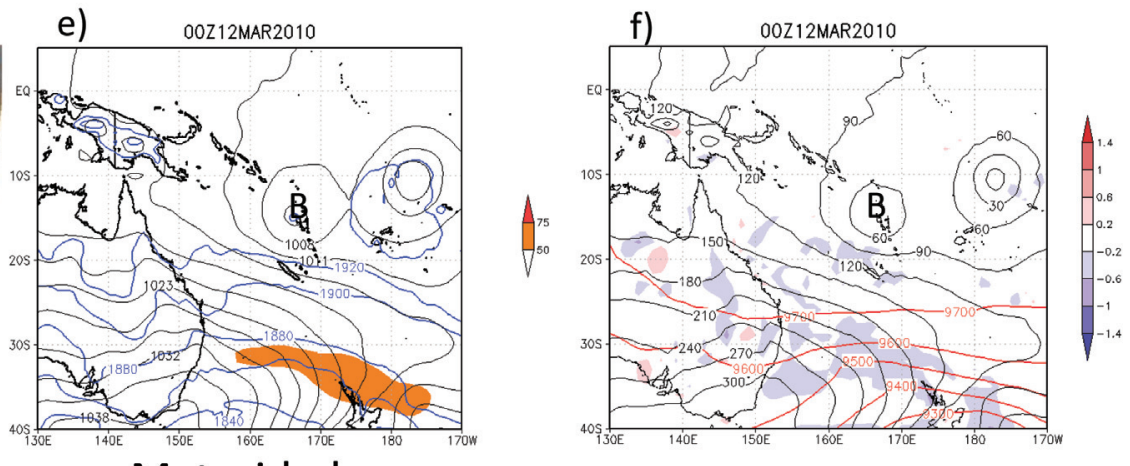

Maturidade

g)

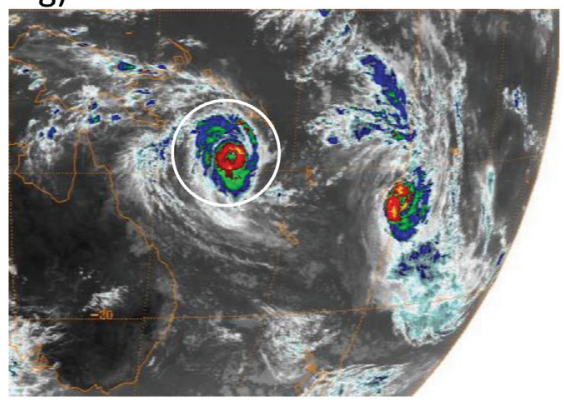

h)

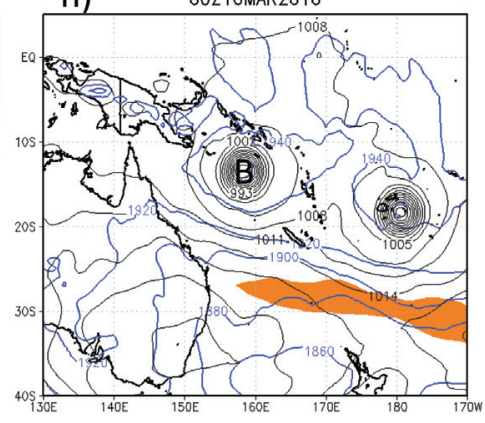

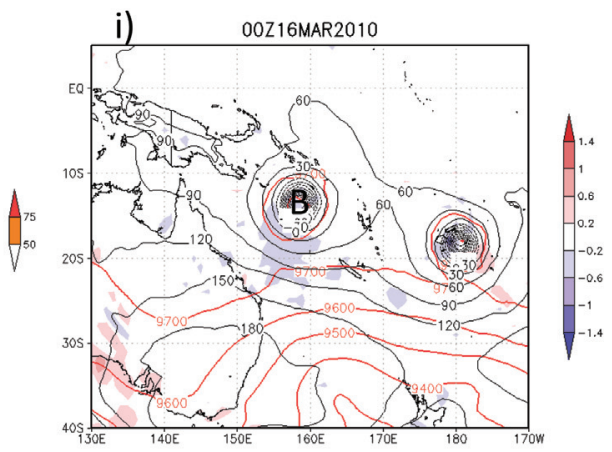

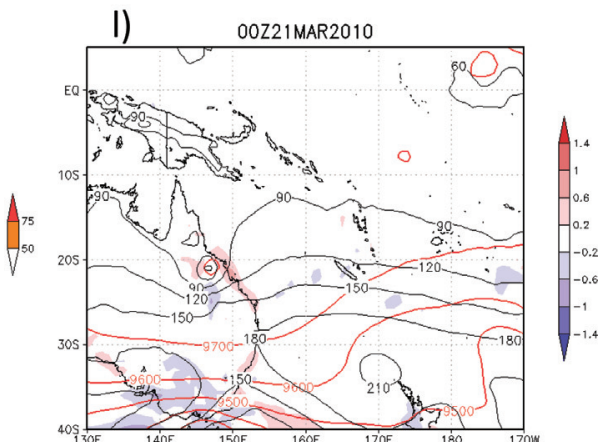

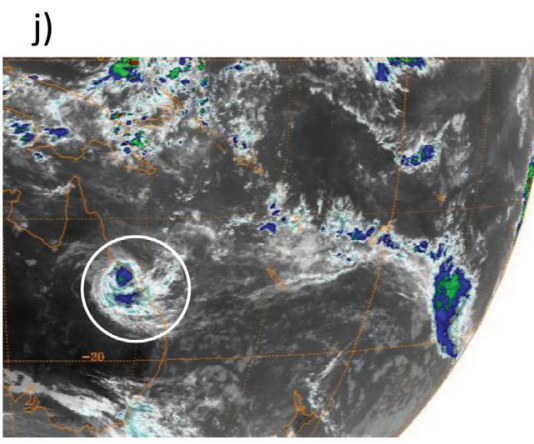

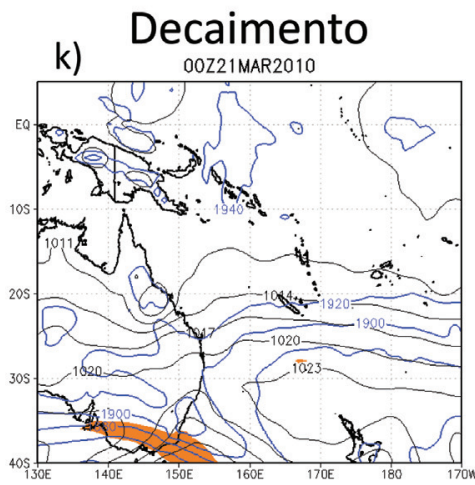

Figura 11 - Ciclo de vida do ciclone tropical nos estágios: pré-ciclogênese (a-c), ciclogênese (d-f), maturidade (g-i) e decaimento (j-1). A coluna da esquerda apresenta as imagens do satélite MTSAT1R no canal infravermelho (sendo o ciclone delimitado por um círculo branco), a coluna central mostra a pressão ao nível médio do mar (hPa, linha preta), a espessura da camada $850 / 1000 \mathrm{hPa}$ (metros, linha azul) e a intensidade do vento ( $\mathrm{m} \mathrm{s}^{-1}$ ) em $200 \mathrm{hPa}$ (preenchido). A coluna da direita mostra a altura geopotencial em $1000 \mathrm{hPa}$ (linha preta) e em $300 \mathrm{hPa}$ (linha vermelha) e a advecção horizontal de temperatura do ar em $1000 \mathrm{hPa}\left({ }^{\circ} \mathrm{C} /\right.$ hora, preenchido). Nas figuras, a letra B indica a localização do centro de baixa pressão. 
cavado de onda curta em $500 \mathrm{hPa}$ (Fig. 14c). Este cavado se restringiu ao nível de $500 \mathrm{hPa}$ não mostrando assinatura em $300 \mathrm{hPa}$ (diferente dos demais casos analisados no presente estudo e, por isso, para o ciclone subtropical foi mostrada a altura geopotencial em $500 \mathrm{hPa}$ ao invés de $300 \mathrm{hPa}$ ). A Fig. 14b indica que tal cavado foi importante para a manutenção de movimentos ascendentes sob a região a jusante do seu eixo (Fig. 15b). Além disso, o fraco cisalhamento vertical do vento na camada $200-925 \mathrm{hPa}\left(\sim 10 \mathrm{~m} \mathrm{~s}^{-1}\right.$ que é abaixo da média climatológica de cerca de $26 \mathrm{~m} \mathrm{~s}^{-1}$ na região; figs. não mostradas) também pode ter favorecido o aprofundamento da convecção local. Na superfície oceânica, sob a região de nebulosidade, a TSM é de $27^{\circ} \mathrm{C}$ (com anomalia de $+1{ }^{\circ} \mathrm{C}$ ) e os fluxos de calor total (latente + sensível) de $200 \mathrm{~W} \mathrm{~m}^{-2}$ (figs. não apresentadas), similares ao valor climatológico mostrado por Reboita et al. (2010). Entretanto, a diferença entre a TSM e a temperatura do ar a
$2 \mathrm{~m}$ de altura (figs. não mostradas) indica nos estágios de pré-ciclogênese e ciclogênese que o oceano está cerca de $2{ }^{\circ} \mathrm{C}$ mais quente do que a atmosfera, o que provavelmente está contribuindo para o aquecimento da baixa troposfera $\mathrm{e}$ favorecendo os desvios positivos de temperatura do ar mostrados nas Figs. 15 b-d. Estudos como o de Piva et al. (2008) e de Reboita et al. (2012) têm indicado a importância dos fluxos de calor latente e sensível no aquecimento do ar nos níveis mais baixos da atmosfera e na instabilização vertical da atmosfera e favorecimento para as ciclogêneses ao longo da costa leste da América do Sul. Piva et al. (2008) realizou experimentos numéricos em que os fluxos de calor latente e sensível foram desligados concomitantemente no modelo e um de cada vez. Sem ambos os fluxos, o modelo simulou um ciclone mais fraco. De acordo com os autores, a ausência dos fluxos de calor latente e sensível gera uma camada mais seca e mais fria próxima à
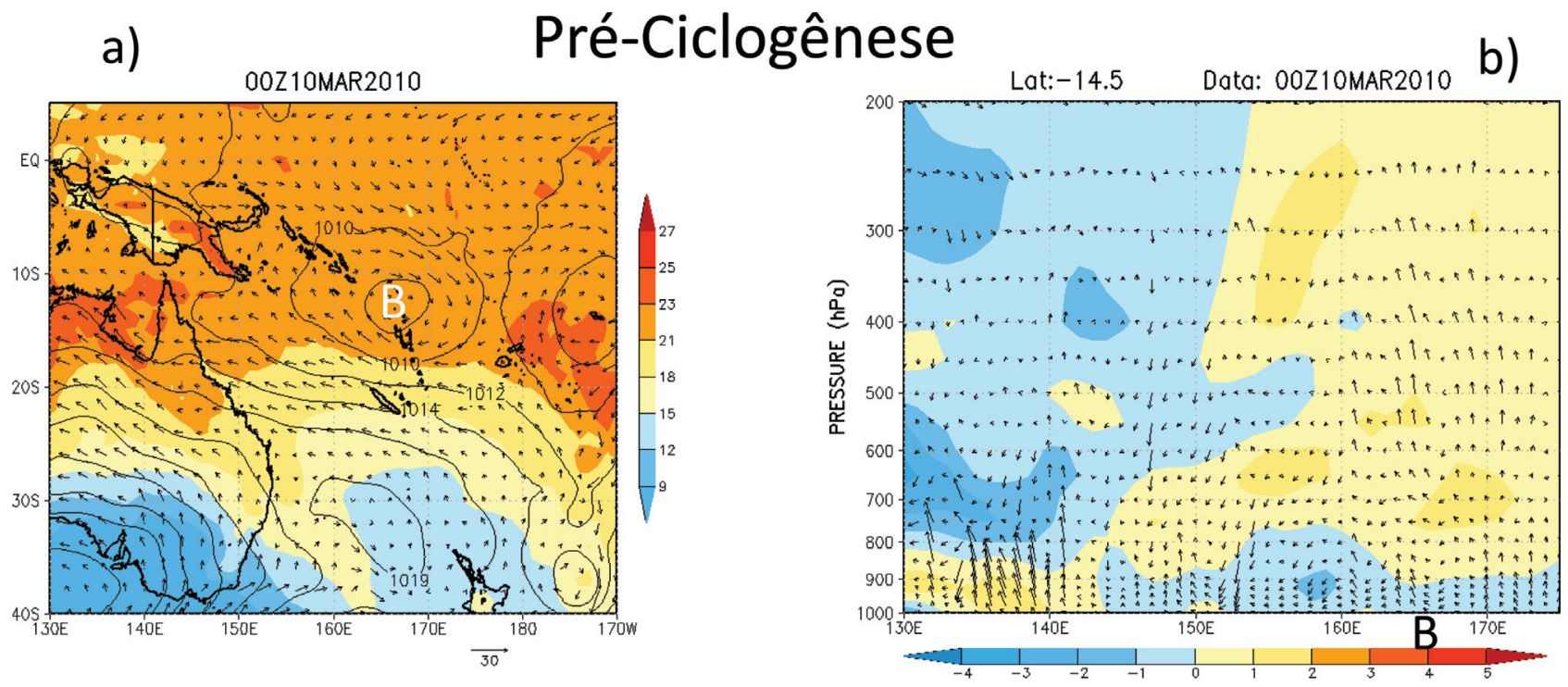

c) Ciclogênese
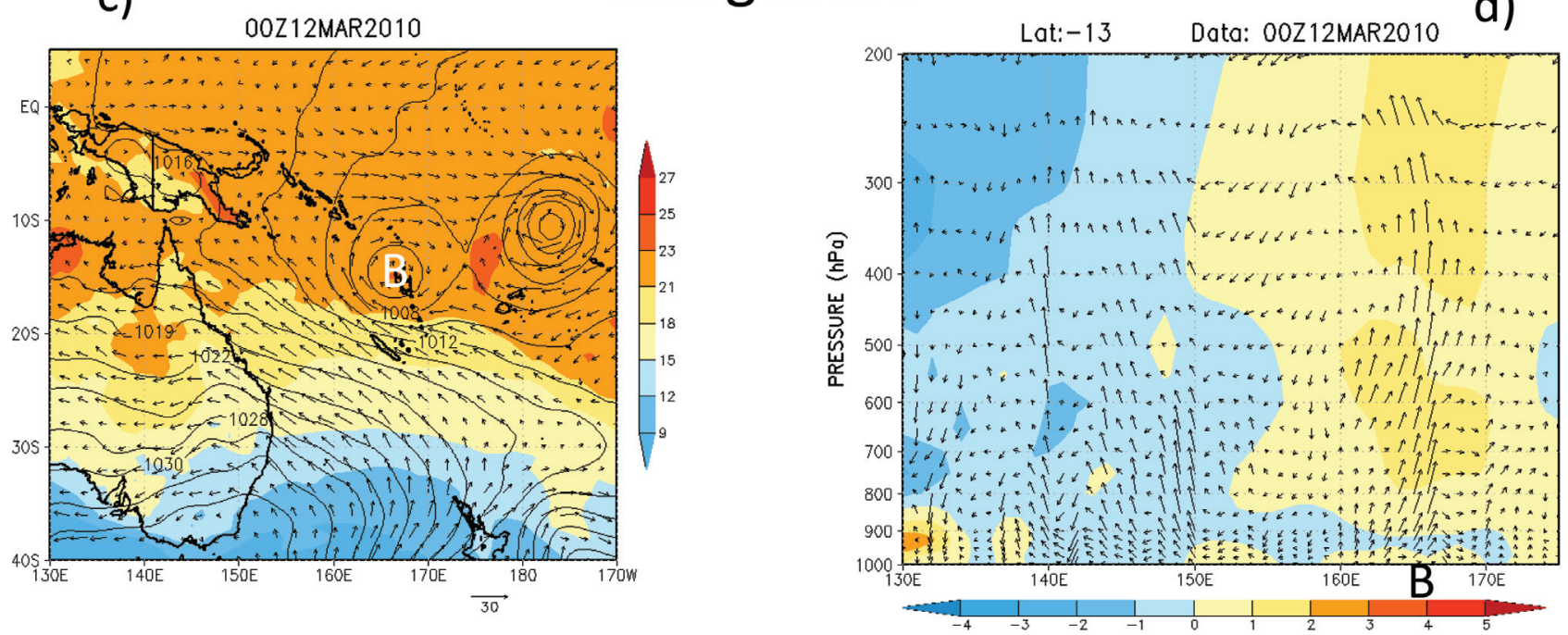

Figura 12 - Similar à Fig. 4, mas para o ciclo de vida do ciclone tropical. 


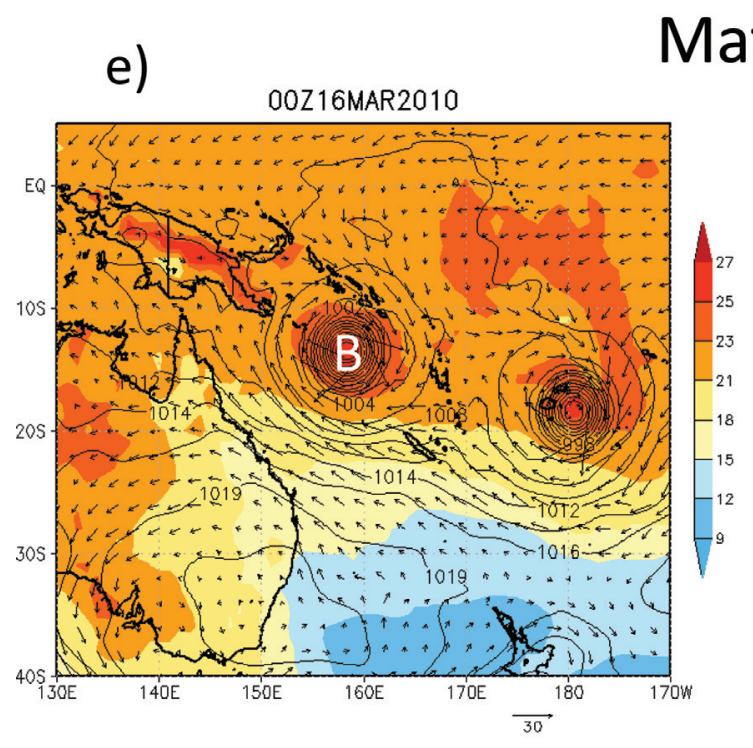

\section{Maturidade}

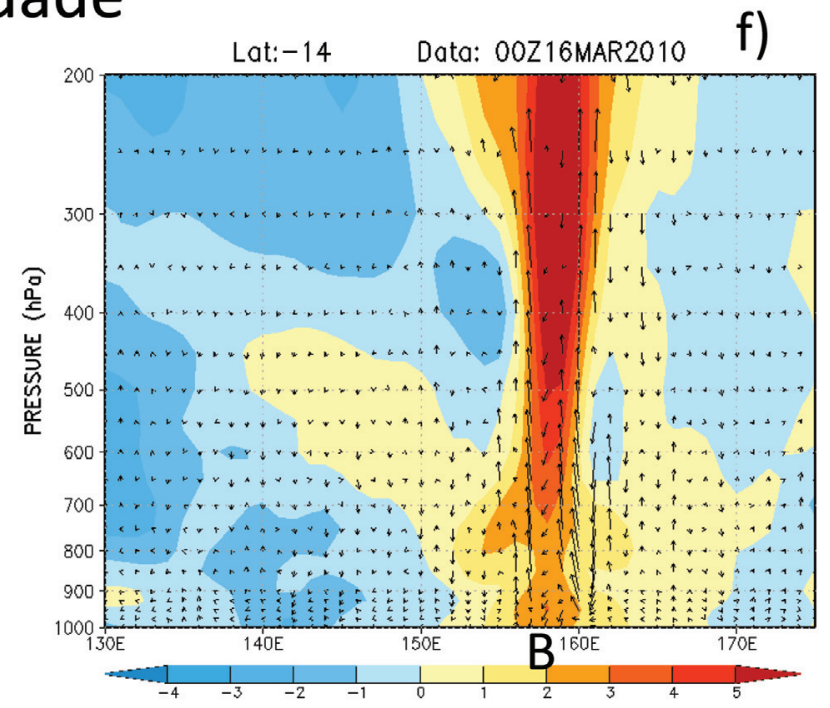

g) $00221 \mathrm{MAR} 2010$ Decaimento
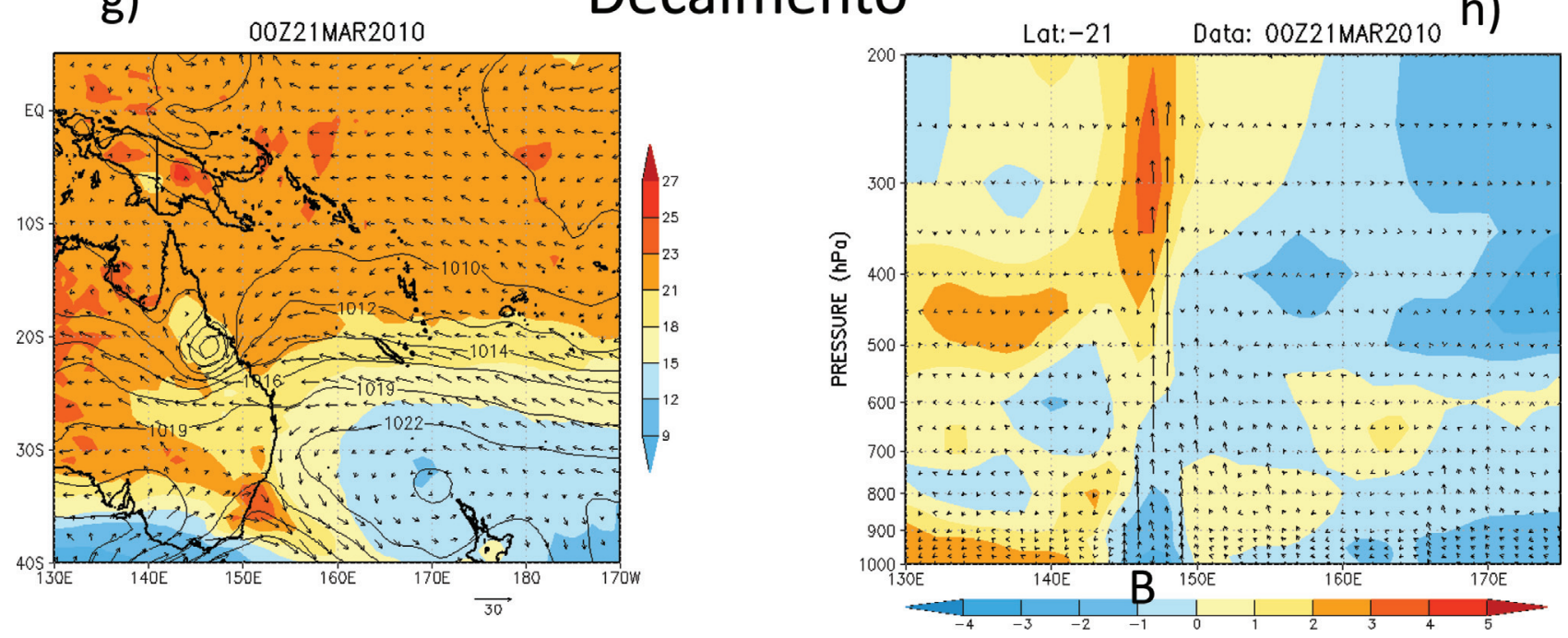

Figura 12 - Continuação.

superfície oceânica, reduzindo a instabilidade potencial do ambiente e diminuindo a intensificação do ciclone. Assim, concluíram que os fluxos de calor em superfície foram importantes antes da fase de mais rápido desenvolvimento do ciclone, agindo no sentido de preparar o ambiente para uma ciclogênese mais intensa, através do fornecimento de energia e umidade na baixa troposfera.

No estágio de pré-ciclogênese, por influência do cavado, há em superfície um centro de vorticidade relativa ciclônica entre $50^{\circ} \mathrm{W}$ e $40^{\circ} \mathrm{W}$ (Fig. 16a). Já no perfil vertical da atmosfera (Fig. 15b), centrado em $19^{\circ} \mathrm{S}$, essa região com vorticidade ciclônica também é caracterizada por desvio zonal positivo de temperatura do ar, estendendo-se até cerca de $700 \mathrm{hPa}$ (Fig. 15b), quando o desvio passa a ser negativo entre 600 e $500 \mathrm{hPa}$ (provavelmente associado ao eixo do cavado em $500 \mathrm{hPa}$ ). Portanto, o ambiente pré-ciclogenético já indica uma estrutura híbrida no campo térmico.

\subsubsection{Ciclogênese (1200Z do dia 14/03/2011)}

Às $1200 \mathrm{Z}$ do dia 14/03/11 uma isóbara se fecha com valor de $1006 \mathrm{hPa}$ (Fig. 14e) apresentando maior nebulosidade no seu setor sul e sudeste (Fig. 14d). Nesse estágio, o setor a jusante do cavado ainda se encontra sobre o sistema em superfície (Fig. 14f) e como as linhas de espessura da camada 500/1000 hPa não cruzam o centro do ciclone, isso indica a ausência de baroclinia (Fig. 14e), o que caracteriza o sistema como não-frontal. $\mathrm{O}$ ciclone analisado também praticamente não produz advecção horizontal de temperatura (Fig. 14f). Por outro lado, o desvio zonal positivo de temperatura do ar é intensificado no centro do sistema na camada entre 1000 e $900 \mathrm{hPa}$ (Fig. 15d), comparado ao estágio de pré-ciclogênese. Como esse aquecimento ocorre sobre a região em que está localizada a corrente do Brasil (fig. não mostrada), sugere-se que o aquecimento ocorra devido aos fluxos de calor latente e sensível em superfície. 
a)

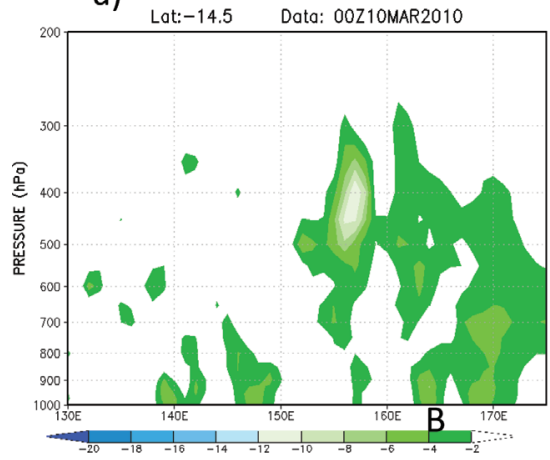

d)

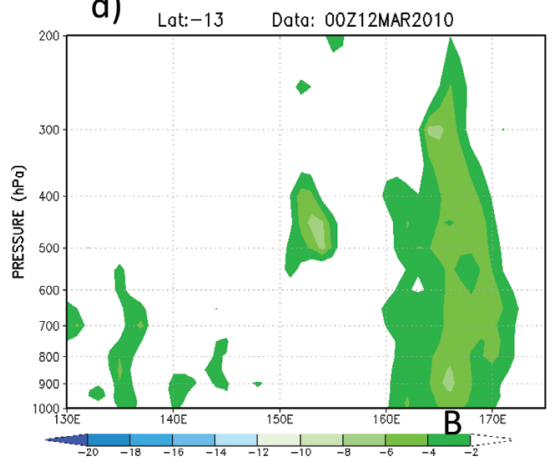

g)
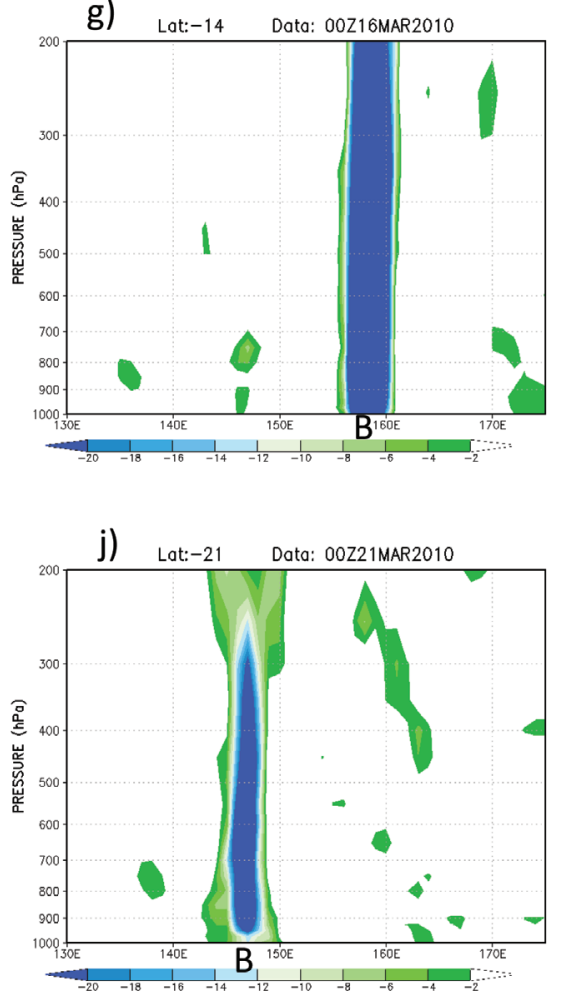

b) Pré-Ciclogênese

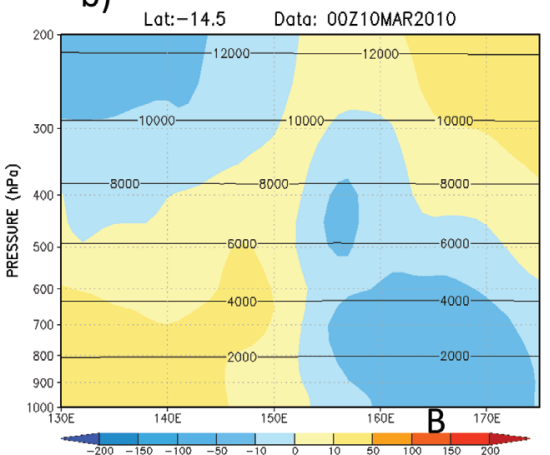

Ciclogênese

e) Lat:-13 Data: 00Z12MAR2010

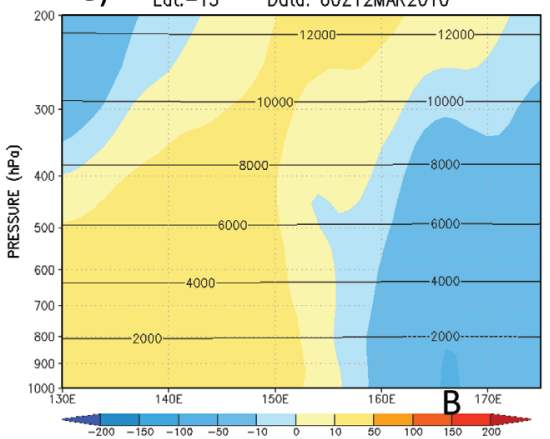

Maturidade

h)
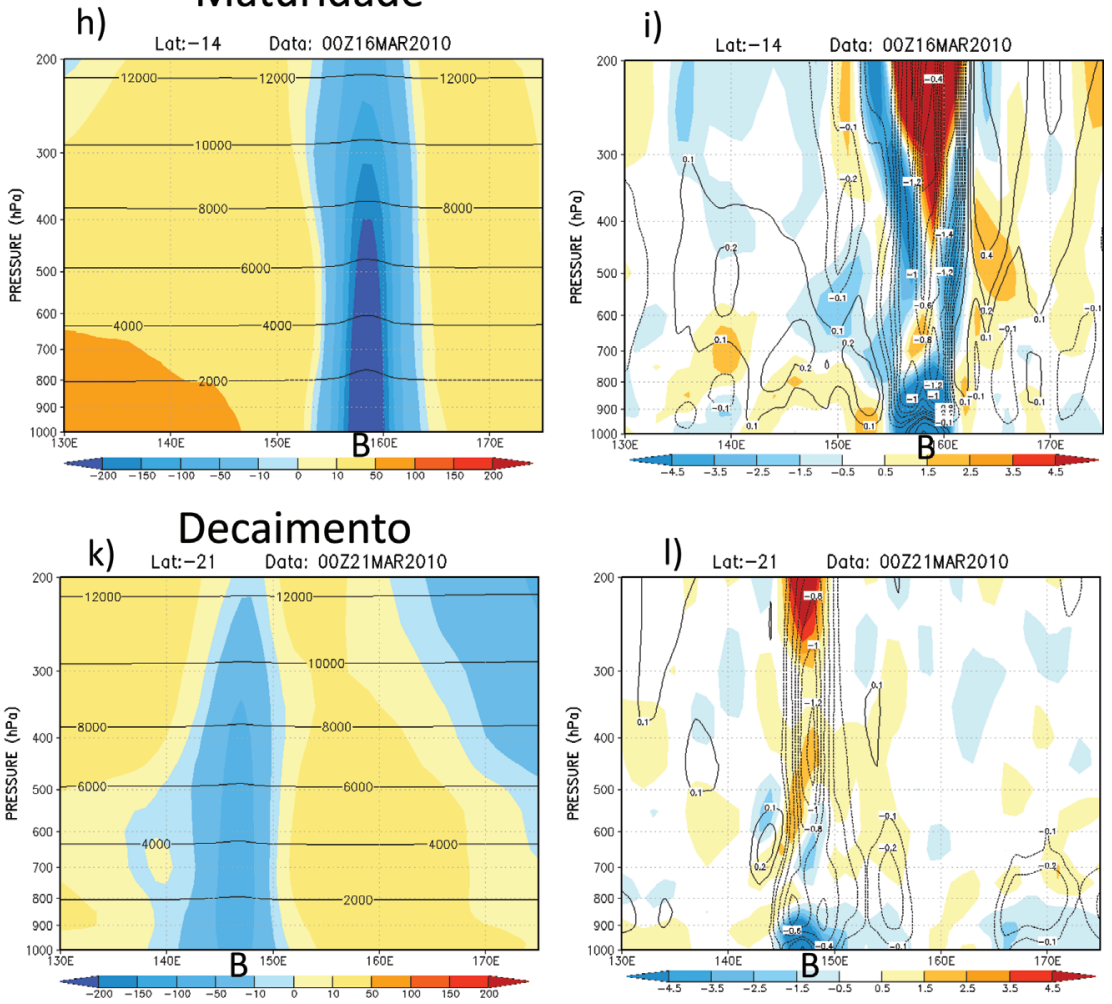

c)

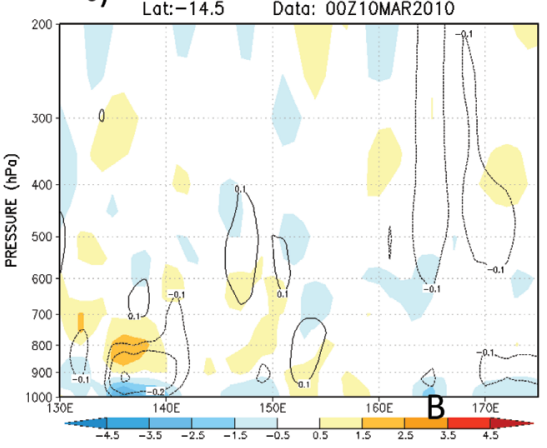

f) Lat:-13 Data: 00Z12MAR2010
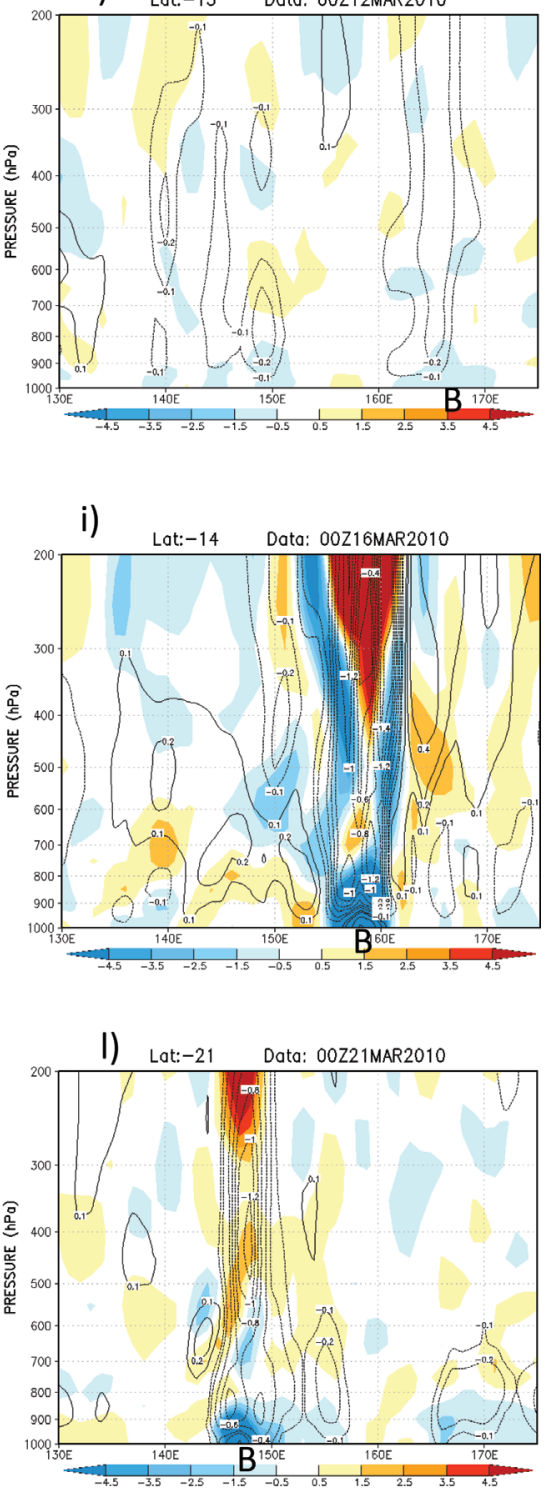

Figura 13 - Similar à Fig. 5, mas para o ciclo de vida do ciclone tropical. 
a)

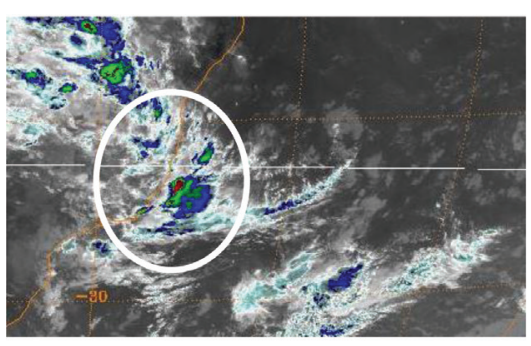

d)

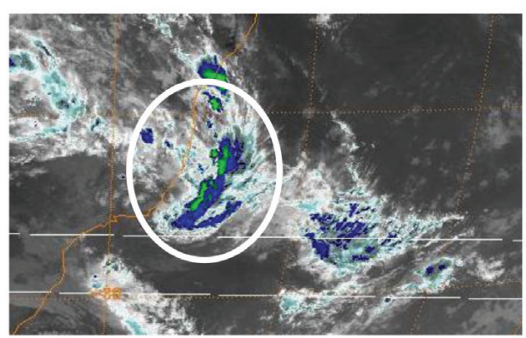

g)

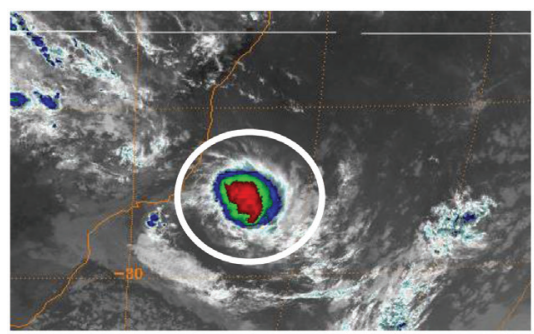

j)

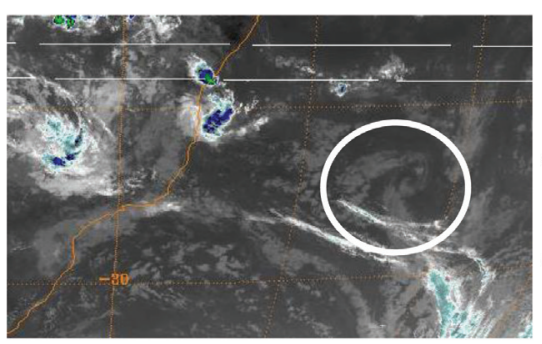

\section{b)}

Pré-Ciclogênese

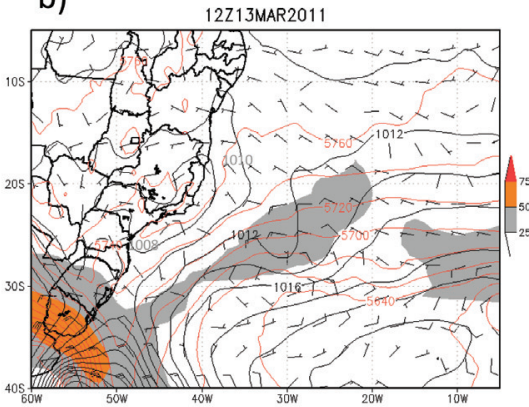

e) Ciclogênese

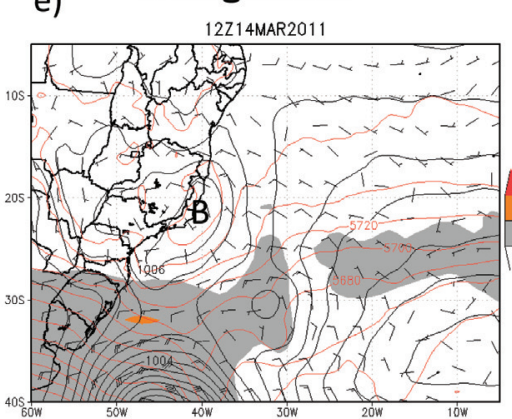

h) Maturidade

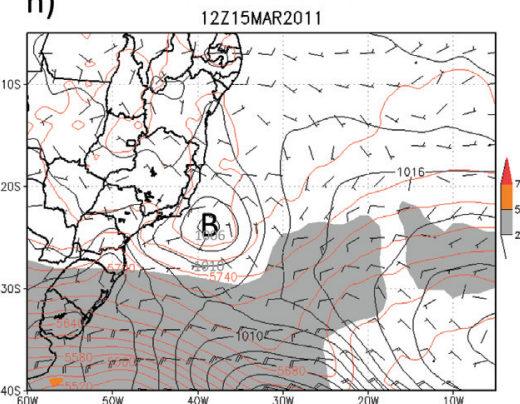

k) Decaimento

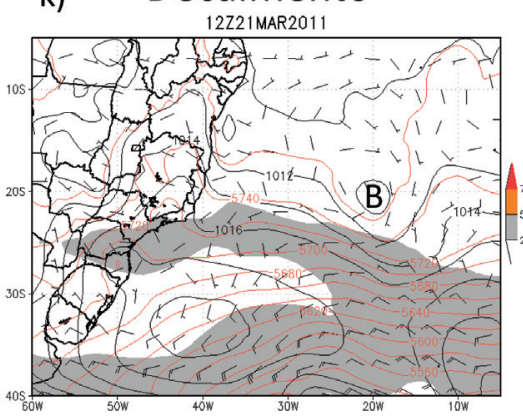

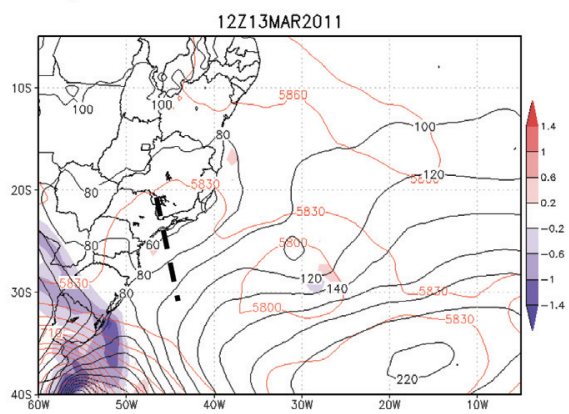

f)

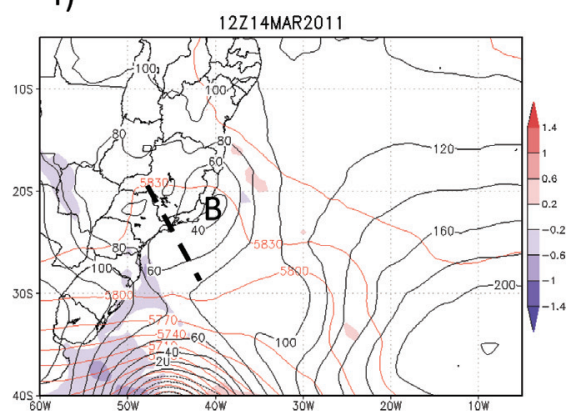

\section{i)}

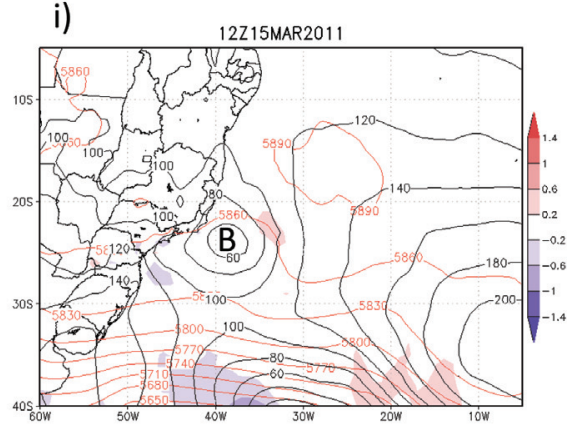

I)

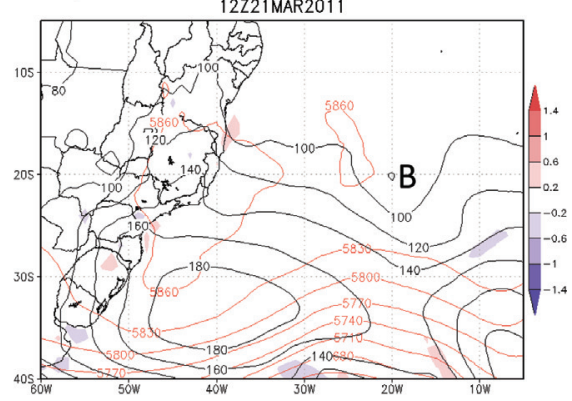

Figura 14 - Ciclo de vida do ciclone subtropical nos estágios: pré-ciclogênese (a-c), ciclogênese (d-f), maturidade (g-i) e decaimento (j-1). A coluna da esquerda apresenta as imagens do satélite MTSAT1R no canal infravermelho (sendo o ciclone delimitado por um círculo branco), a coluna central mostra a pressão ao nível médio do mar ( $\mathrm{hPa}$, linha preta), a espessura da camada 500/1000 hPa (metros, linha vermelha), as barbelas da intensidade e direção do vento em $500 \mathrm{hPa}$ e intensidade do vento $\left(\mathrm{m} \mathrm{s}^{-1}\right)$ em $200 \mathrm{hPa}$ (preenchido). A coluna da direita mostra a altura geopotencial em $1000 \mathrm{hPa}$ (linha preta) e em $500 \mathrm{hPa}$ (linha vermelha), a advecção horizontal de temperatura do ar em $1000 \mathrm{hPa}\left({ }^{\circ} \mathrm{C} /\right.$ hora, preenchido). Nas figuras, a letra B indica a localização do centro de baixa pressão e a linha preta pontilhada, o centro do cavado em $500 \mathrm{hPa}$.

Já o desvio negativo entre 600 e 500 hPa é enfraquecido. No presente estágio, o tubo vertical de vorticidade relativa ciclônica mostra-se melhor configurado, mas restringindo-se da superfície até o nível de 400 hPa e sem inclinação na vertical (Fig. 16d); o desvio zonal negativo de altura geopotencial também se torna mais definido (Fig. 16e) e há um centro de convergência em superfície nos arredores de $40^{\circ} \mathrm{W}$ (Fig. 16f). Uma característica interessante no siste- 
ma em estudo é que tanto os ventos em superfície quanto o movimento vertical ascendente são mais intensos a leste do núcleo do ciclone (Figs. 15c-d).

\subsubsection{Maturidade (1200Z do dia 15/03/2011)}

Do estágio de ciclogênese para o de maturidade, o ciclone quase não se desloca e a isóbara central continua apresentando valor de $1006 \mathrm{hPa}$. Como o centro do cavado de onda curta em $500 \mathrm{hPa}$ sobrepõe-se ao centro do ciclone em superfície (Fig. 14i), caracterizando um padrão barotrópico, o tubo vertical de vorticidade relativa ciclônica se expande até cerca de $200 \mathrm{hPa}$, mas com os maiores valores de vorticidade (em módulo) limitados ao nível de $600 \mathrm{hPa}$ (Fig. 16g). O centro do sistema em superfície permanece com desvio zonal positivo de temperatura de até $3{ }^{\circ} \mathrm{C}$ que agora se expande até $600 \mathrm{hPa}$ (Fig. 15f). Acima desse nível os desvios enfraquecem, mas permanecendo positivos (quentes). $\mathrm{O}$ aquecimento mais afastado da superfície pode ser decorrente da liberação de calor latente no processo de condensação. Desse estágio até alcançar o decaimento, o ciclone desloca-se para sudeste, ainda acoplado com o cavado em $500 \mathrm{hPa}$, com estrutura térmica (sempre mais quente próximo à superfície do que em $500 \mathrm{hPa}$ ) e tubo de vorticidade relativa ciclônica muito similar ao do estágio de maturidade, exceto, pelo tubo de vorticidade se estender apenas até $400 \mathrm{hPa}$ (fig. não mostradas). Às $0000 \mathrm{Z}$ do dia 20/03/2014 a baixa em superfície se desacopla do cavado em $500 \mathrm{hPa}$ e tem uma ligeira migração para noroeste (Fig. 14k).

\subsubsection{Decaimento (1200Z do dia 21/03/2011)}

Com o desacoplamento da baixa em superfície com o cavado em $500 \mathrm{hPa}$ (Fig. 141), o ciclone fica embebido num cavado invertido no campo de pressão em superfície. Com a falta de um suporte dinâmico em níveis mais elevados, a convergência em superfície (Fig. 161) e o movimento vertical ascendente (Fig. 16h) enfraquecem, o que leva o ciclone à dissipação. Entretanto, o desvio zonal positivo de tempe- a)

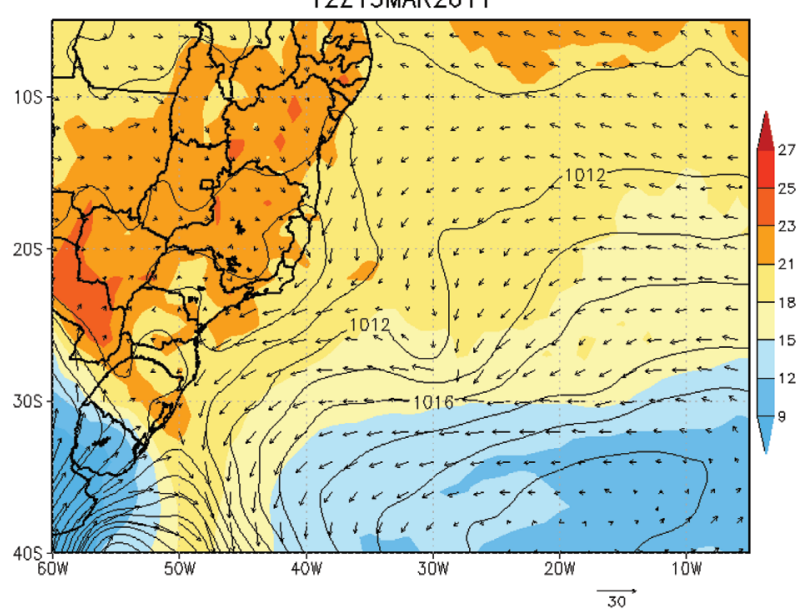

\section{Pré-Ciclogênese}

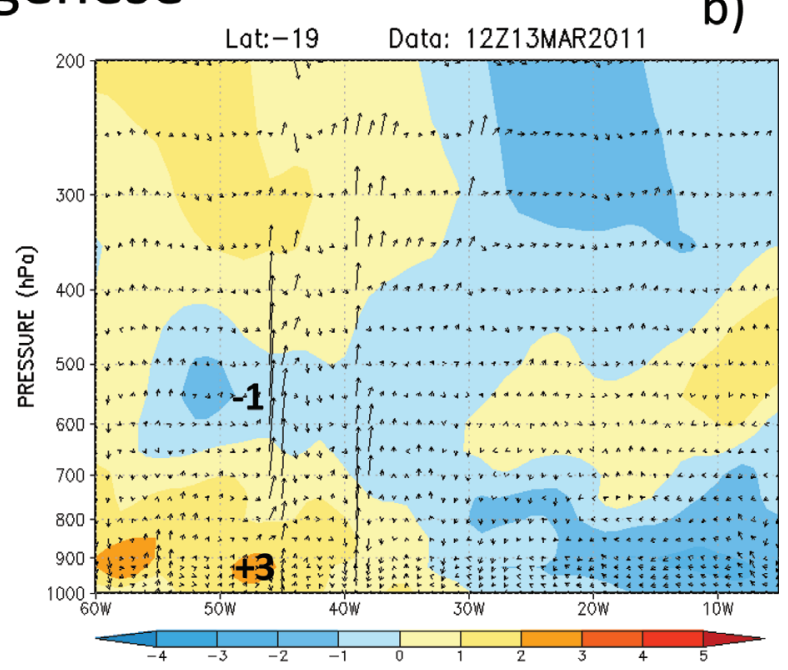

c)
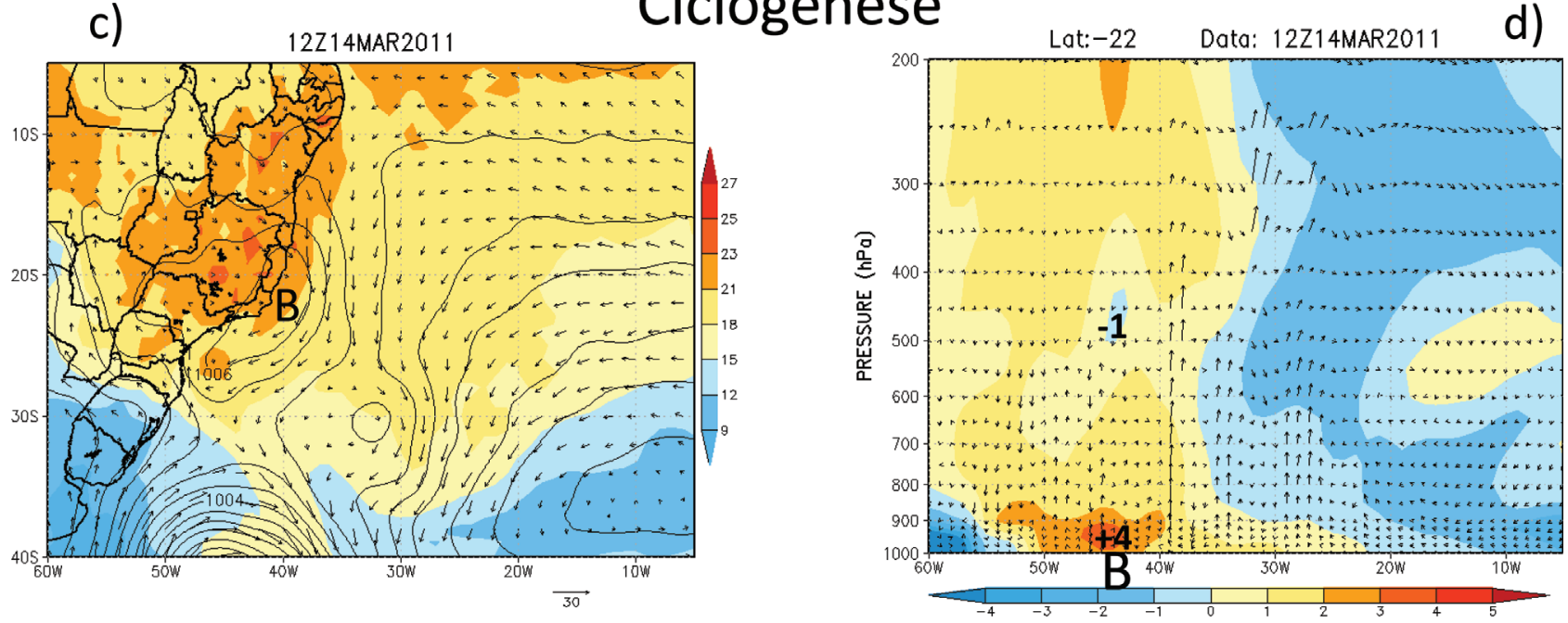

Figura 15 - Similar à Fig. 4, mas para o ciclo de vida do ciclone subtropical. 

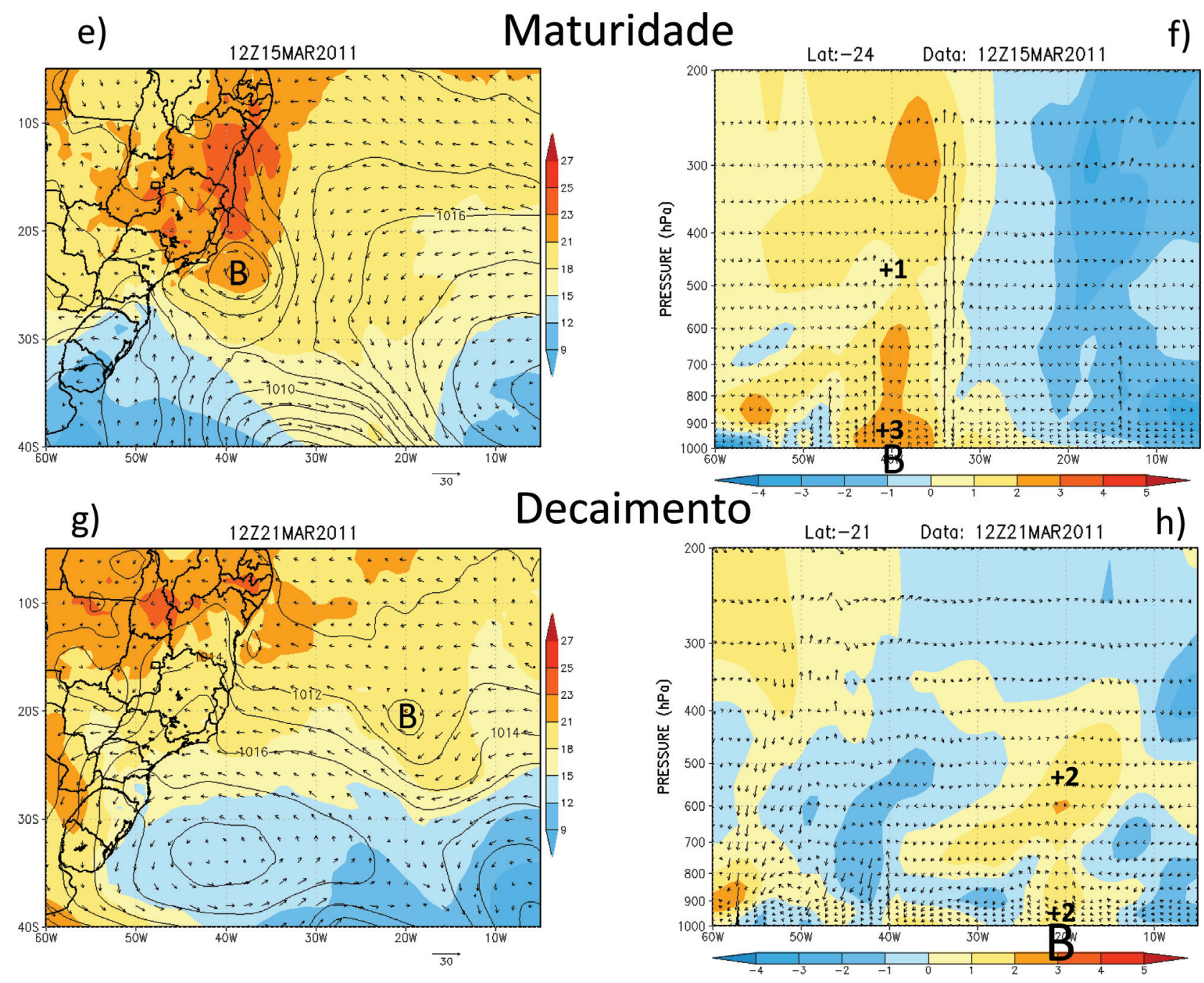

Figura 15 - Continuação.

ratura ainda é predominante no núcleo do sistema com valor de $2{ }^{\circ} \mathrm{C}$ entre 1000 e $400 \mathrm{hPa}$, mas em níveis mais altos o desvio torna-se negativo.

É interessante destacar que ao longo do ciclo de vida do ciclone subtropical, os ventos mais intensos predominaram a leste do centro do ciclone (o que concorda com as características

dos sistemas estudados por Herbert e Poteat, 1975) bem como o núcleo do sistema em baixos níveis foi mais quente do que em médios e altos níveis. Com relação aos ventos mais intensos a leste do ciclone estudado, isso ocorre em função do maior gradiente horizontal de pressão a leste como mostrado na Fig. 15 (coluna esquerda).

\subsection{Caracterização do tipo de ciclone: Cyclone Phase Space}

Hart (2003) desenvolveu uma metodologia, com base na estrutura térmica dos ciclones, para caracterizar "os tipos" de ciclone que um determinado sistema adquire ao longo do seu ciclo de vida. Tal metodologia é chamada de
Cyclone Phase Space (CPS). Os tipos de estruturas são classificados pela simetria, intensidade do desvio de temperatura e profundidade vertical.

O CPS utiliza os seguintes parâmetros: simetria térmica do ciclone $(B)$, vento térmico em baixos níveis $\left(V_{T}^{L}\right)$ e vento térmico em altos níveis $\left(V_{T}^{U}\right)$.

\subsubsection{Simetria térmica do ciclone (B)}

Para avaliar se um ciclone é frontal (ciclone extratropical) ou não-frontal (ciclone tropical), calcula-se o parâmetro $B$. Para tanto, (a) a partir do centro do ciclone traça-se um raio de $500 \mathrm{~km}$ e, na sequência, define-se um círculo; (b) com base no vetor deslocamento do sistema divide-se o círculo em dois semicírculos; (c) em cada semicírculo calcula-se a espessura da camada 600-900 hPa e computa-se o valor médio da espessura e (d) com o valor médio da espessura obtido em cada semicírculo define-se a diferença entre o valor do semicírculo localizado a direita $(R)$ e a esquerda $(L)$ do vetor deslocamento: 
a)

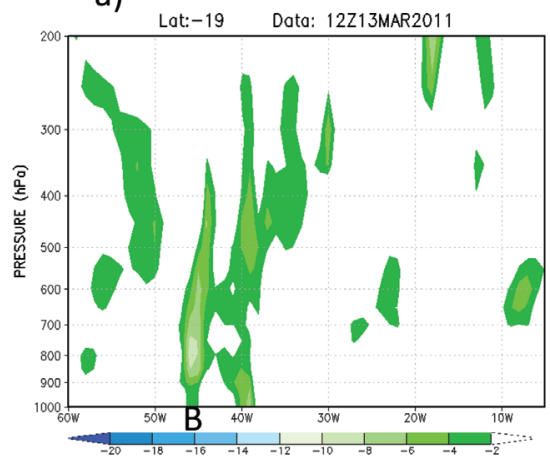

d)

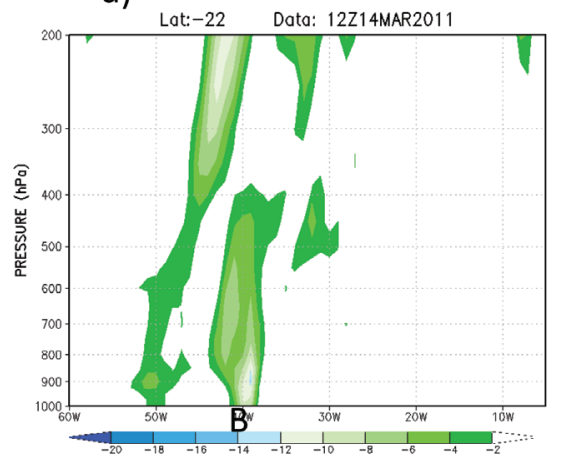

g)

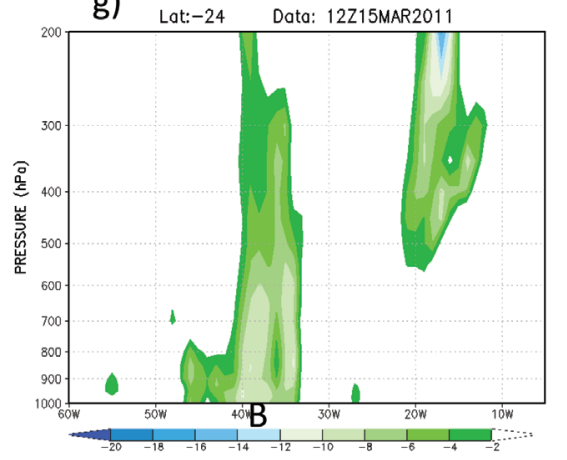

j)

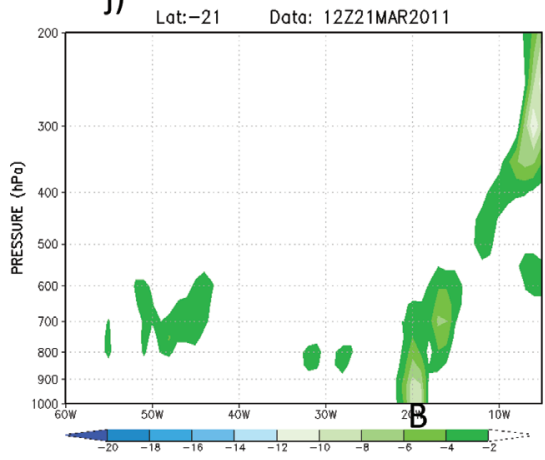

Pré-Ciclogênese

b)

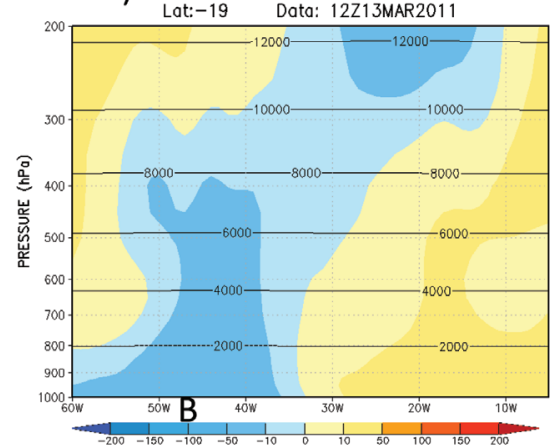

Ciclogênese

e)

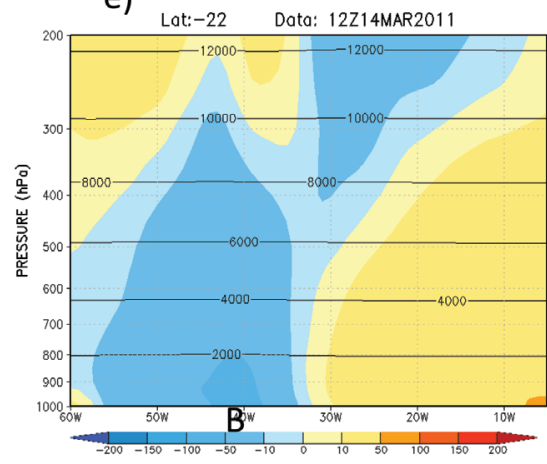

h) Maturidade

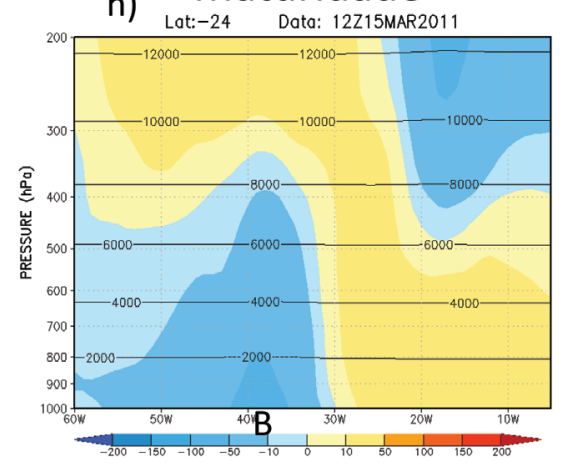

k) Decaimento

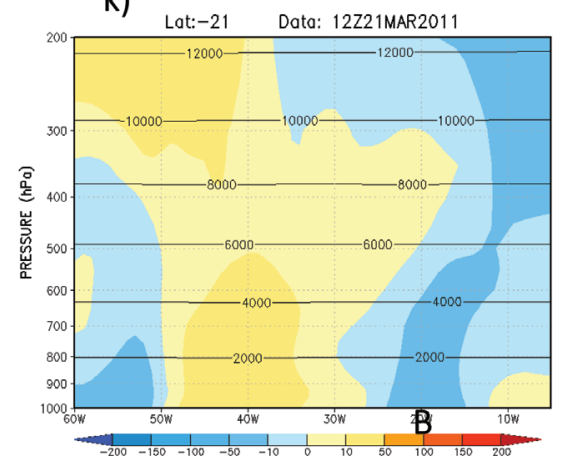

c)

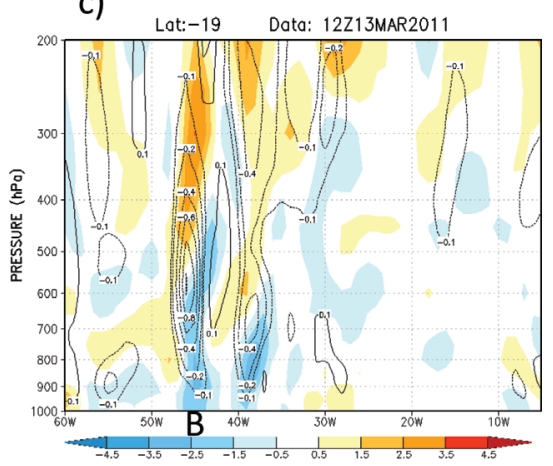

f)
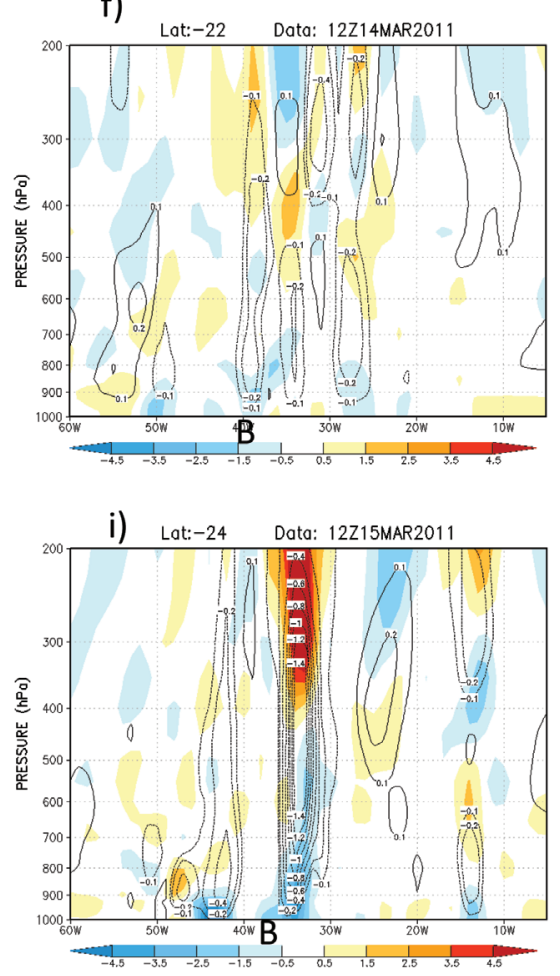

l)

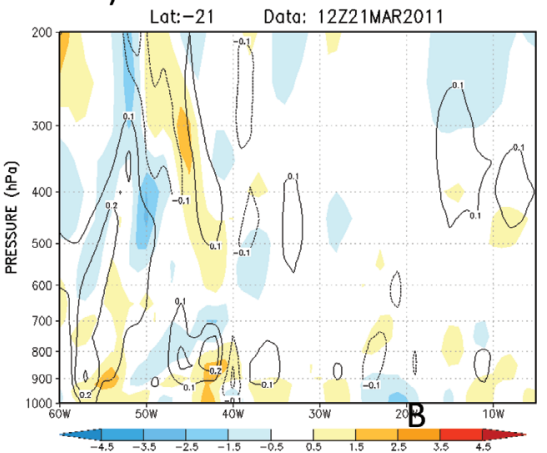

Figura 16 - Similar à Fig. 5, mas para o ciclo de vida do ciclone subtropical.

$$
B=h\left[\left(\overline{Z_{600 h P a}-Z_{90 h P a}}\right)_{R}-\left(\overline{Z_{600 h P a}-Z_{900 h P a}}\right)_{L}\right]
$$

onde $Z$ é a altura geopotencial em metros, $R$ e $L$ indicam os lados direito e esquerdo do círculo, respectivamente, que tem a divisão realizada com base no vetor deslocamento, e 


\section{Ciclone Extratropical Tipo Bjerknes e Solberg (1922)}

a)

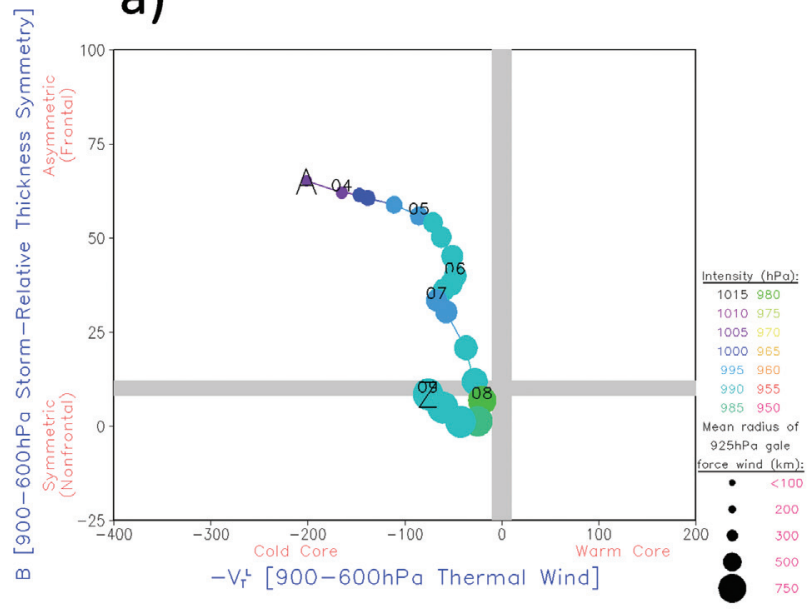

b)

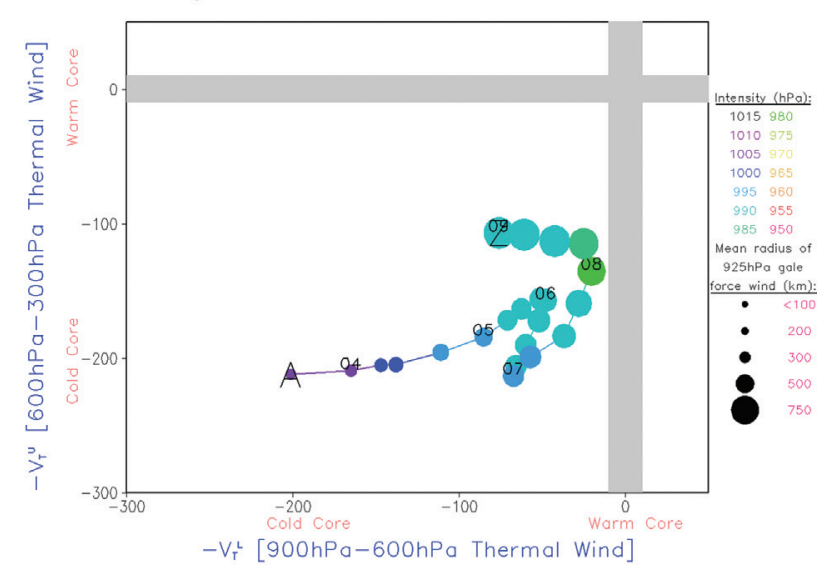

\section{Ciclone Extratropical Tipo Shapiro e Keyser (1990)}
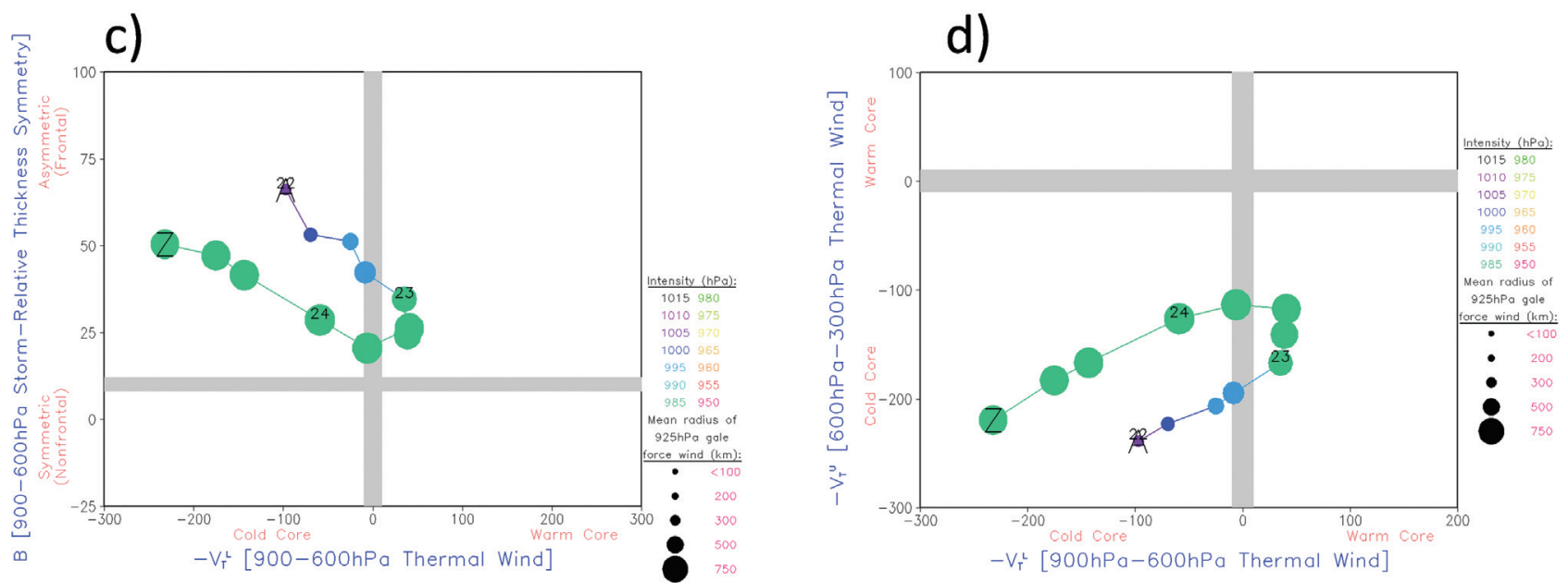

Figura 17 - Cyclone phase space dos ciclones extratropicais (a-b) tipo Bjerknes e Solberg (1922) e (c-d) Shapiro e Keyser (1990). Ver texto para maiores detalhes.

$h$ representa o sinal positivo $(+)$ no Hemisfério Norte e negativo (-) no Hemisfério Sul.

Como os ciclones extratropicais na fase inicial e de desenvolvimento são frios na retaguarda e quente na vanguarda da frente fria isso implica em menor espessura da camada no lado frio $(R)$ e em maior espessura no lado quente $(L), \operatorname{logo}$ a diferença entre os lados $R$ e $L$ do círculo na Eq. (1) será negativa, mas em função do sinal de $\mathrm{h}$ (negativo no Hemisfério Sul) ela será positiva e mostrando $B \gg$ 0. Já no caso dos ciclones tropicais, como esses sistemas apresentam o núcleo sem gradientes intensos de temperatura do ar, praticamente não há diferenças entre os lados $R$ e $L$ e, assim, $-10 \mathrm{~m}<B<10 \mathrm{~m}$ (Hart, 2003). Para os ciclones subtropicais, o valor de $B$ é superior a $10 \mathrm{~m}$, mas não muito elevado.

\subsubsection{Vento térmico $\left(V_{T}^{L}\right.$ e $\left.V_{T}^{U}\right)$}

Nos extratrópicos, os gradientes horizontais de pressão se intensificam com a altura, com consequente intensificação do vento geostrófico. Por outro lado, nos trópicos como estes gradientes são fracos, os ventos mais fortes são observados em superfície (Holton, 2004; Aguado e Burt, 2010).

Quando existe gradiente horizontal de pressão há diferenças na altura geopotencial $\left(\Delta Z=Z_{\max }-Z_{\min }\right)$ em uma dada superfície de pressão e nos ventos. A diferença vetorial do vento geostrófico entre duas superfícies de pressão constante caracteriza o vento térmico $\left(\mathrm{V}_{\mathrm{T}}\right)$. Esse vento é apenas teórico e escoa paralelamente às isotermas de tal forma que deixa os maiores valores de temperatura a sua esquerda no Hemisfério Sul e a direita no Hemisfério Nor- 


\section{Ciclone Tropical Ului}
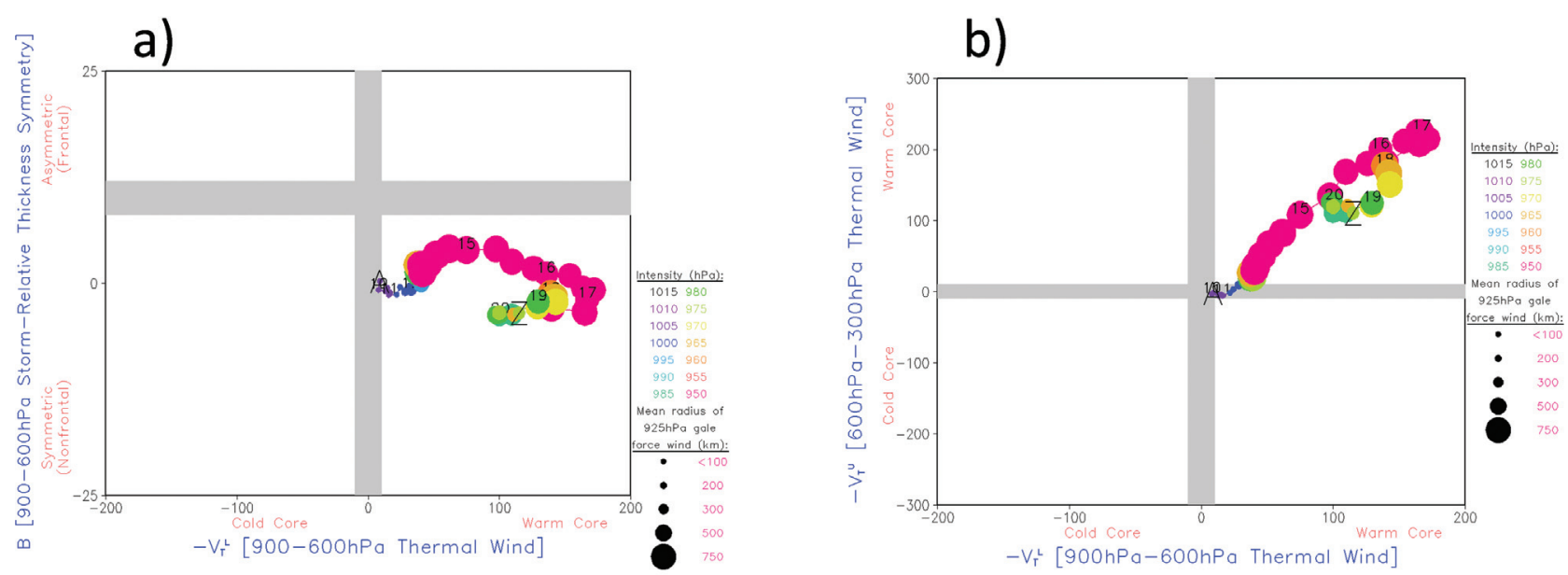

\section{Ciclone Subtropical Arani}

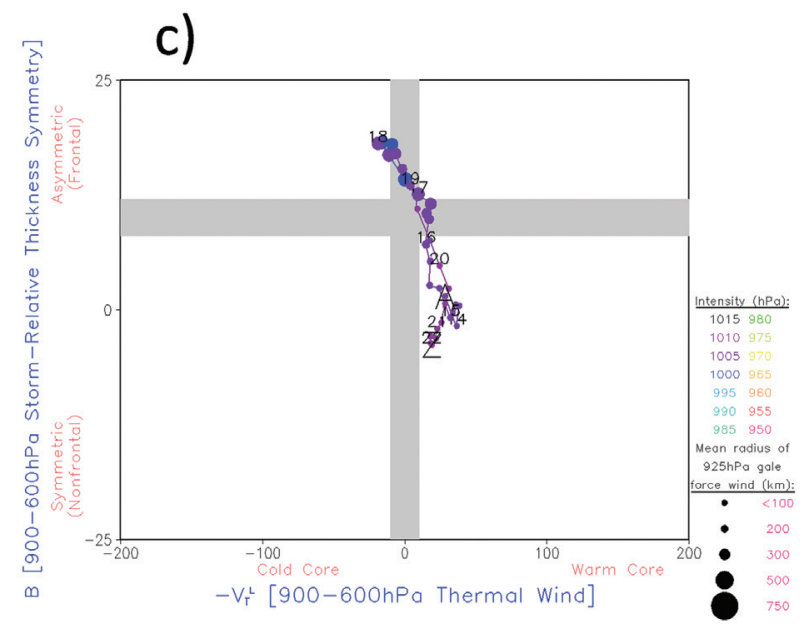

d)

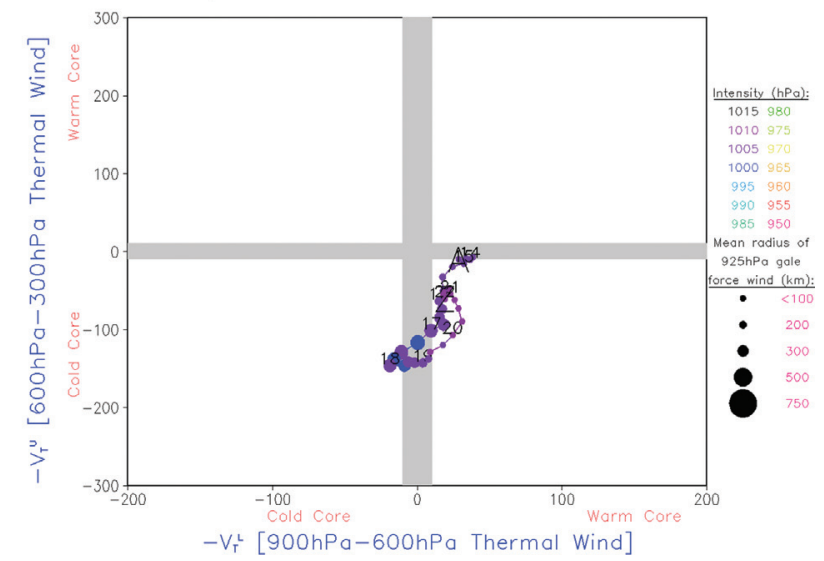

Figura 18 - Cyclone phase space dos ciclones (a-b) tropical Ului e (c-d) subtropical Arani. Ver texto para maiores detalhes.

te. Através de alguns rearranjos matemáticos, verifica-se que o $\mathrm{V}_{\mathrm{T}}$ é proporcional ao gradiente horizontal de espessura, Eqs. (2) e (3) (que por sua vez é proporcional ao gradiente horizontal de temperatura média na camada). Assim, quanto maior o gradiente horizontal de espessura entre duas superfícies, maior será a magnitude do vento térmico dentro dessa camada (e, lembrando que esse é paralelo às linhas de espessura).

Através do $\mathrm{V}_{\mathrm{T}}$ determinado em diferentes camadas atmosféricas é possível obter uma medida da força de um ciclone. Isso está associado ao fato de que em um ciclone extratropical o vento intensifica com a altitude enquanto em um tropical, reduz. Portanto, uma vez calculadas as Eqs. (2) e (3) é possível, através do $V_{T}$, definir o "tipo" de ciclone.

$$
\begin{aligned}
& -V_{T}^{L}\left|=\frac{\partial\left(Z_{\max }-Z_{\min }\right)}{\partial \ln p}\right|_{900}^{600}= \\
& \frac{\left.\left(Z_{\max }-Z_{\text {min }}\right)\right|_{600}-\left.\left(Z_{\max }-Z_{\min }\right)\right|_{900}}{\ln 600-\ln 900} \\
& -V_{T}^{U}\left|=\frac{\partial\left(Z_{\max }-Z_{\min }\right)}{\partial \ln p}\right|_{600}^{300}= \\
& \frac{\left.\left(Z_{\max }-Z_{\min }\right)\right|_{300}-\left.\left(Z_{\max }-Z_{\min }\right)\right|_{600}}{\ln 300-\ln 600}
\end{aligned}
$$

onde os índices $L$ e $U$ denotam as camadas entre 900-600 hPa e 600-300 hPa, respectivamente, para o cálculo do vento térmico e $Z_{\max }-Z_{\min }$ indicam a diferença entre os valores máximo e mínimo de altura geopotencial dentro do círculo previamente definido $(500 \mathrm{~km})$ e nos níveis especificados. 
Para facilitar o entendimento das equações, considere o exemplo em que $\Delta Z_{300 \mathrm{hPa}}=Z_{\max }-Z_{\min }=50, \Delta Z_{600 \mathrm{hPa}}=Z_{\max }$ - $Z_{\text {min }}=350 \mathrm{~m} \mathrm{e} \Delta Z_{900 \mathrm{hPa}}=Z_{\max }-Z_{\min }=400 \mathrm{~m}$. Só pelos valores obtidos já é nítido que há pouca variação na altura geopotencial à medida que se sobe na atmosfera e, portanto, não há uma intensificação dos ventos com a altura. Fazendo: $\Delta Z_{300 \mathrm{hPa}}-\Delta Z_{600 \mathrm{hPa}}=-300 \mathrm{~m} \mathrm{e} \Delta Z_{600 \mathrm{hPa}}-\Delta Z_{900 \mathrm{hPa}}=$ -50 m; porém ainda é necessário dividir o resultado por $\ln 300-\ln 600$, no primeiro caso, e por $\ln 600-\ln 900$, no segundo, o que irá mudar o sinal dos resultados. Assim, tem-se como resultado final um valor positivo e bem maior do que zero. Portanto, quando $-\left|V_{T}^{U}\right||>>0 \mathrm{e}-| V_{T}^{L} \mid>>0$ há um enfraquecimento do vento com a altura, o que indica um ciclone com centro quente (ciclone tropical). $\mathrm{O}$ resultado inverso ocorre no caso do ciclone com núcleo frio (ciclone extratropical). No caso de um ciclone subtropical, esse apresenta núcleo quente em baixos níveis, mas não tão intenso quanto o do ciclone tropical, de forma que $-\left|V_{T}^{L}\right|>0$ e frio em altos níveis, mas não tão intenso quanto o do ciclone extratropical, de forma que $-\left|V_{T}^{U}\right|<0$. Os valores que indicam a presença de um sistema de núcleo frio e quente são sumarizados na Tabela 1 .

Os parâmetros do CPS podem ser representados graficamente em diagramas. Em geral, plota-se $B$ com $-\left|V_{T}^{L}\right|$ e $-\left|V_{T}^{L}\right| \mathrm{e}-\left|V_{T}^{U}\right|$. Esses diagramas foram construídos para cada ciclone estudado a fim de caracterizar o "tipo" de cada um deles.

É importante destacar que o parâmetro $B$ não pode ser comparado diretamente com as figuras do corte vertical do desvio zonal de temperatura do ar, mostradas nas seções anteriores. Para tais figuras, o desvio zonal foi calculado em relação à média zonal da temperatura entre todas as longitudes mostradas nas figuras, que é uma área muito mais extensa do que os $\sim 5^{\circ}$ de raio $(500 \mathrm{~km})$ usados na determinação do parâmetro $B$.

Ciclone extratropical do tipo Bjerknes e Solberg (1922): a Fig. 17a mostra o parâmetro $B$, que indica a temperatura do núcleo do sistema com base num raio de $500 \mathrm{~km}$ (que é uma distância menor do que a usada para computar os desvios zonais de temperatura do ar mostrados nas seções prévias) na camada $600-900 \mathrm{hPa}$, juntamente com o parâmetro $-\mid V_{T}^{L}$, que indica tanto a variação vertical

Tabela 1 - Parâmetros do CPS para ciclones tropicais, subtropicais e extratropicais; baseado em Evans e Hart (2003), Hart (2003), Guishard (2006) e Evans e Guishard (2009).

\begin{tabular}{lccc}
\hline Tipo & $\boldsymbol{B}(\mathbf{m})$ & $-\left|\boldsymbol{V}_{\boldsymbol{T}}{ }^{L}\right|$ & $-\left|\boldsymbol{V}_{\boldsymbol{T}}^{U}\right|$ \\
\hline Tropical & $-10<B<10$ & $-\left|V_{T}^{L^{L}}\right|>>0$ & $-\left|V_{T}^{U}\right|>>0$ \\
Subtropical & $\begin{array}{c}\text { Varia mas não adquire } \\
\text { valores grandes }\end{array}$ & $-\left|V_{T}^{L}\right|>0$ & $-\left|V_{T}^{U}\right|<0$ \\
& $B>10$ & $-\left|V_{T}^{L}\right|<<0$ & $-\left|V_{T}^{U}\right|<<0$ \\
Extratropical & &
\end{tabular}

da temperatura quanto a variação vertical da intensidade do vento no núcleo do sistema na camada $600-900 \mathrm{hPa}$. Com base na Fig. 17a, durante a gênese do ciclone (dia $03 / 05 / 2013$ às $18 Z$ ), o parâmetro $B$ possui valor positivo e maior do que zero $(75 \mathrm{~m})$, o que indica a existência de gradientes horizontais de temperatura e, portanto, um ciclone extratropical. Para um ciclone extratropical também se espera que $-\left|V_{T}^{L}\right|<<0$ e, isso, foi o que ocorreu no caso em estudo (valor de -200).

Os parâmetros $-\left|V_{T}^{L}\right|$ e $-\left|V_{T}^{U}\right|$, na Fig. 17b, indicam a variação vertical da temperatura e da intensidade do vento no centro dos sistemas em baixos e altos níveis, respectivamente. Ainda considerando a gênese do ciclone, esses parâmetros possuem valores bem negativos (de aproximadamente -200), indicando que há variação da intensidade do vento com a altura (isto é, a intensidade vento aumenta com o aumento da altitude) e, portanto, o sistema é extratropical.

Do período de ciclogênese (dia 03/05/2013 às 1800Z) até a oclusão (dia 08/05/2013 às 0000Z), os valores de $B$ e $-V_{T}^{L} \mid$ enfraquecem tornando-se mais próximos de zero (Fig. 17a). O $-V_{T}^{U} \mid$ também enfraquece, mas não se torna inferior a -100 (Fig. 17b). Da oclusão ao decaimento do sistema, os valores de $B$ chegam próximos a zero indicando o desaparecimento dos gradientes horizontais de temperatura, ou em outras palavras, o surgimento de um sistema não-frontal. De fato, foi mostrado na Fig. 4e-h que o ciclone a partir da fase de oclusão possui temperatura quase homogênea e essa característica se reflete no CPS.

Numa forma resumida, o ciclone iniciou com a presença de gradientes horizontais de temperatura $(B>>0)$ e com valores bem negativos de $-\left|V_{T}^{L}\right| \mathrm{e}-\left|V_{T}^{U}\right|$, o que indica a existência de aumento da intensidade do vento com o aumento da altura, características de um ciclone extratropical. Do estágio de oclusão ao decaimento, os valores de $B$ tornam-se próximos de zero, indicando um campo de temperatura mais homogêneo no centro do ciclone. O padrão do CPS obtido na análise desse caso de ciclone é característico dos ciclones extratropicais do tipo Bjerknes e Solberg, conforme Hart (2003).

Ciclone extratropical do tipo Shapiro e Keyser (1990): no dia 22/11/2014 (Fig. 17c), os valores de $B$ são bem maiores do que zero (entre 50 e $75 \mathrm{~m}$ ), indicando a presença de gradiente horizontal de temperatura no centro do ciclone e, consequentemente, a existência de um ciclone extratropical. Os valores de $-V_{T}^{L} \mid$ também são bem negativos (-100) mostrando que os ventos aumentam de intensidade com a altura dentro da camada analisada. $\mathrm{O}$ aumento da intensidade dos ventos com a altura também pode ser visualizado através de valores mais negativos em 
$-\left|V_{T}^{U}\right|$ comparados aos de $-\left|V_{T}^{L}\right|$ na Fig. 17d. Todas essas características configuram a existência do ciclone extratropical.

No dia 23/11/2014, os valores de $B$ decrescem indicando a redução do gradiente de temperatura no centro do sistema, o que concorda com as Figs. 8e-f mostradas previamente. Já $-V_{T}^{L} \mid$ passa a mostrar valores com sinal oposto ao do dia anterior, isto é, valores positivos e próximos de zero (Fig. 17c), ou seja, redução da intensidade dos ventos com o aumento da altura, levando a indicação da seclusão de ar quente no centro do sistema extratropical (fase da warm seclusion do modelo conceitual de Shapiro e Keyser, 1990). Entretanto, a camada $600-300 \mathrm{hPa}$ ainda é caracterizada por ventos mais intensos com a altura, pois $-\left|V_{T}^{U}\right|<<0$ (Fig. 17d). A configuração do CPS (Fig. 17d), com $-\left|V_{T}^{L}\right|>0$ e $-\left|V_{T}^{U}\right|<<0$, indica que a seclusão de ar quente ocorre em baixos níveis da atmosfera (núcleo quente), mas não em altos níveis, o que também é mostrado na Fig. 8f. Esse padrão obtido é similar ao documentado por Hart (2003) no caso do ciclone tipo Shapiro e Keyser ocorrido no oceano Atlântico Norte em fevereiro de 1982.

Por fim, o dia 24/11/2014 é marcado por um aumento nos três parâmetros do CPS (em módulo no caso do vento térmico) indicando a inexistência da seclusão de ar quente. Após esse dia o sistema é "embebido" num cavado transiente. Em resumo, o ciclone extratropical na sua gênese estava associado com gradiente horizontal de temperatura do ar, na maturidade teve uma seclusão de ar quente no seu centro, no estágio seguinte voltou a apresentar gradiente de temperatura e, decaiu por influência da circulação de latitudes médias.

Ciclone tropical: a evolução do ciclone tropical Ului foi representada no CPS desde o estágio de pré-ciclogênese (dia 10/03/2010). Do dia 10 a 11, os três parâmetros calculados mostram valores praticamente nulos (Fig. 18 a-b). Entretanto, a partir do dia 12/03 (dia em que ocorre a ciclogênese) até o decaimento do sistema, os valores do parâmetro $B$ oscilam entre cerca de -10 e $10 \mathrm{~m}$ indicando a ausência de gradiente horizontal de temperatura no núcleo do sistema, característica de um ciclone tropical (Fig. 18a). Em todo o ciclo de vida do ciclone, os parâmetros $-\left|V_{T}^{L}\right|$ e $-\left|V_{T}^{U}\right|$ foram positivos (Fig. 18b), o que mostra ventos sem intensificação com a altura e existência de um sistema de núcleo quente. Em resumo, o ciclone Ului teve gênese e decaimento como ciclone tropical. Além disso, seu CPS é similar ao do ciclone tropical Mitch ocorrido em 1998 no Caribe e documentado por Hart (2003).

Ciclone subtropical: enquanto o ciclone extratropical tem uma preferência pelo lado esquerdo dos diagramas CPS e o tropical pelo direito, o subtropical fica confinado na parte central (Figs. $18 \mathrm{c}$-d). Em todo o ciclo de vida do ciclone subtropical os valores de $B$ não excederam a $20 \mathrm{~m}$
(Fig. 18c). Portanto, valores baixos de $B$ indicam a ausência de gradientes horizontais de temperatura no núcleo do sistema e, logo, a presença de um núcleo quente na camada 900-600 hPa. Essa informação também é sinalizada através dos valores positivos de $-V_{T}^{L} \mid$ (no mesmo gráfico). Como os valores de $B$ são um pouco maiores do que os obtidos no caso do ciclone tropical, tem-se que o núcleo quente é mais fraco no caso do ciclone subtropical. O parâmetro $-\left|V_{T}^{L}\right|$ também indica valores muito próximos a zero, ou seja, ausência de ventos intensificando com a altura na camada. Até aí as características do CPS para o ciclone subtropical se assemelham às do tropical, porém a diferença mais significativa entre esses sistemas ocorre em relação ao $-\left|V_{T}^{U}\right|$

(Fig. 18d), cujos valores no ciclone subtropical, nos dias 18 e 19 , alcançam cerca de -200 , o que indica a existência de ventos aumentando com a altura, característica típica de ciclones extratropicais. Tal evidência confirma que o ciclone tem núcleo híbrido. De acordo com as análises da seção 3.4 e dos diagramas do CPS, o Arani nasce e decai como ciclone subtropical. O CPS desse sistema é muito similar ao do ciclone subtropical Anita (Dias Pinto et al., 2013), exceto no estágio final, pois o Anita teve transição para extratropical.

\section{Conclusões}

Este trabalho teve como objetivo apresentar as características sinóticas de quatro tipos de ciclones em latitudes austrais, extratropical seguindo o modelo conceitual de Bjerknes e Solberg, extratropical seguindo o modelo de Shapiro e Keyser, tropical e subtropical, a fim de servir de referência básica nos cursos de meteorologia ou para aqueles interessados no tema. Para evidenciar as diferenças entre os quatro tipos de ciclones, é elaborada a seguinte síntese:

- ciclones extratropicais: a presença de um ambiente baroclínico (gradiente horizontal de temperatura do ar) em superfície e a proximidade de um cavado na alta troposfera (300 hPa) são fatores importantes para a gênese desses sistemas. Os perfis verticais mostram, na fase de ciclogênese, uma inclinação para oeste com o aumento da altura do tubo de vorticidade relativa ciclônica e do desvio zonal negativo de altura geopotencial e, na fase de maturidade, um alinhamento vertical desses, indicando uma atmosfera barotrópica equivalente, semelhante ao que foi observado por Randel e Stanford (1985) para as ondas baroclínicas do Hemisfério Sul. Quanto ao desvio zonal de temperatura do ar, em ambas as fases (ciclogênese e maturidade), há desvios positivos a leste do centro do ciclone e negativos a oeste. Na fase de ciclogênese, já é fácil identificar os sistemas em imagens de satélite pelo padrão de vírgula invertida da nebulosidade (concordando com o modelo conceitual de Troup e Streten, 1972). Na fase de maturidade, o padrão da nebulosidade torna-se espiralado. As características apre- 
sentadas, em geral, ocorrem tanto nos ciclones extratropicais que seguem o modelo conceitual de Bjerknes e Solberg (1922) quanto o de Shapiro e Keyser (1990).

Com relação aos dois modelos conceituais de ciclones extratropicais estudados, na gênese dos sistemas as linhas de espessura 500/1000 hPa cruzam o centro do ciclone, indicando a presença de baroclinia. Nesse momento, o jato em altos níveis tende a passar sobre uma parte do quadrante norte do sistema ciclônico que está em superfície. Na maturidade dos dois tipos de ciclone, as linhas de espessura 500/1000 hPa e de temperatura do ar em $850 \mathrm{hPa}$ se assemelham às dos modelos conceituais apresentados na Fig. 5 de Reboita et al. (2017), isto é, no ciclone tipo Bjerknes e Solberg tais isolinhas mostram maiores temperaturas adentrando em direção ao centro do ciclone pelo lado leste desse, enquanto que no ciclone tipo Shapiro e Keyser há uma seclusão de ar quente no centro do sistema. Após os sistemas atingirem a fase de oclusão, diminui a energia potencial para ser convertida em cinética e os ciclones tendem a decair. Nessa fase do ciclo de vida, as linhas de espessura, em geral, não cruzam mais o centro dos ciclones e sim os circundam (o que ficou bem evidente no caso do ciclone do tipo Bjerknes e Solberg) e o ciclone em superfície passa a se localizar no lado polar do jato em altos níveis. Além das semelhanças também existem diferenças nos dois ciclones extratropicais estudados. No ciclone do tipo Bjerknes e Solberg, a frente fria rota ao redor do centro do ciclone em direção à frente quente. Já no ciclone do tipo Shapiro e Keyser, a frente fria tende a se mover perpendicularmente à quente de forma que ambas quase nunca se encontram, o que caracteriza o padrão chamado T-Bone. Com relação ao CPS, o primeiro ciclone estudado (o de maio de 2013) teve sua gênese e decaimento como um típico ciclone extratropical do tipo Bjerknes e Solberg: presença de região frontal, núcleo frio e ventos intensificando com o aumento da altura. Essas características também aparecem no CPS do ciclone tipo Shapiro e Keyser na sua fase inicial, mas na sequencia ocorre a seclusão de ar quente, que é uma das características mais importantes dos ciclones desse tipo.

- ciclones tropicais: a presença de um aglomerado de nuvens com forma assimétrica e uma fraca assinatura de convergência e vorticidade relativa ciclônica em baixos níveis são elementos importantes para a gênese desse tipo de ciclone. Já na fase de ciclogênese, a nebulosidade adquire um padrão simétrico e os perfis verticais mostram um alinhamento vertical do tubo de vorticidade relativa ciclônica, do desvio zonal negativo de altura geopotencial e positivo de temperatura do ar. Além disso, os desvios verticais de temperatura são mais intensos nos níveis médios e altos da atmosfera (acima de $800 \mathrm{hPa}$ ). Fato que está associado ao aquecimento da atmosfera por liberação de calor latente de condensação nas nuvens convectivas. Por outro lado, é na superfície que os ventos do ciclone tropical são mais intensos. O decaimento do ciclone estudado ocor- reu quando este atingiu a superfície continental por interrupção do fornecimento de fluxos de calor latente do oceano para a atmosfera e fricção com a superfície; o que é comum para a dissipação da maioria dos ciclones tropicais. No CPS, os ciclones tropicais são identificados quando os parâmetros calculados se concentram no lado direito dos diagramas, o que indica sistema com núcleo quente e ventos com pouca ou nenhuma intensificação com o aumento da altitude.

- ciclones subtropicais a gênese está associada com uma forçante dinâmica podendo ser um cavado ou um VCAN em médios e/ou altos níveis da atmosfera. No caso do Arani havia um cavado de onda curta com pouca amplificação em $500 \mathrm{hPa}$, mas que foi importante para a manutenção dos movimentos verticais ascendentes, a sua jusante. Os ciclones subtropicais apresentam estrutura térmica híbrida com núcleo mais quente próximo à superfície e mais frio acima da camada quente. É importante destacar que o núcleo quente dos ciclones subtropicais é muito mais fraco e raso do que o encontrado nos ciclones tropicais; o mesmo pode ser mencionado para o tubo vertical de vorticidade relativa ciclônica. No caso do ciclone Arani, após a sua gênese, a baixa em superfície se acoplou com o centro do cavado em $500 \mathrm{hPa}$ caracterizando o perfil atmosférico com uma estrutura barotrópica equivalente. Nessa situação, os ventos em superfície foram mais intensos a leste do centro do ciclone. Quando a baixa em superfície se desacoplou do cavado em $500 \mathrm{hPa}$, o Arani ficou confinado num cavado invertido em baixos níveis e acabou por decair totalmente. No CPS, os parâmetros calculados aparecem muito próximos ou sobre os eixos dos diagramas que são características dos ciclones subtropicais.

A análise realizada aqui mostra que os modelos conceituais são importantes para ajudar na compreensão dos ciclones, mas isso não significa que todos os casos na natureza se igualam perfeitamente aos modelos conceituais.

\section{Agradecimentos}

Os autores agradecem ao NCEP pelos dados utilizados, a NOAA e ao CPTEC pelas imagens de satélite e ao CNPq, CAPES e FAPESP (projeto SANSAO) pelo apoio financeiro.

\section{Referências}

AGUADO, E.; BURT, J.E. Understanding Weather and Climate. 5th ed. New York: Prentice Hall, 2010.

AHRENS, D. Meteorology Today: An Introduction to Weather, Climate, and the Environment. 9th ed. Cenage Learning, 2008.

BJERKNES, J.; SOLBERG, H. Life cycle of cyclones and the polar front theory of atmospheric circulation. Geofys. Publ., v. 3, p. 3-18, 1922.

CARLSON, T. Mid-Latitude Weather Systems. Harper Collins, New York, 512 pp, 1991. 
CELEMÍN, A.H. Meteorologia Prática. Edición del Autor, Mar del Plata, República Argentina, 313 pp, 1984.

CHARNEY, J.G. The Dynamics of Long Waves in a Baroclinic Westerly Currents. Journal of Meteorology, p. 135-162, 1947.

COMET (2015). Tropical Cyclones. In: Introduction to Tropical Meteorology. 2a ed. Acesso 11/01/2015, Disponível em: http://www.meted.ucar.edu/tropical/textbook_2nd_edition/ navmenu.php?tab $=9$, acesso em 10 de janeiro de 2015 .

CPTEC. Centro de Previsão de Tempo e Estudos Climáticos. Satélites. Disponível

em: http://satelite.cptec.inpe.br/home/novoSite/index.jsp, acesso em 18 de dezembro de 2014.

DARE, R.A.; DAVIDSON, N.E. Characteristics of Tropical Cyclones in the Australian Region. Mon. Wea. Rev., v. 132, p. 3065-3049, 2004.

DIAS PINTO, J.R.; REBOITA, M.S.; DA ROCHA, R.P. Synoptic and dynamical analysis of subtropical cyclone Anita (2010) and its potential for tropical transition over the South Atlantic Ocean. J. Geophys. Res. Atmos., v. 118, 10,87010,883, 2013.

EMANUEL, K.A. An air-sea interaction theory for tropical cyclones. Part I: Steady state maintenance. J. Atmos. Sci., v. 43, p. 585-604, 1986.

EMANUEL, K.A. The theory of hurricanes. Annual Rev. Fluid Mech., v. 23, p. 179-196, 1991.

EMANUEL, K.A. Tropical Cyclones. 1998 Disponível em: http://wind.mit.edu/ emanuel/geosys/Tropical\%20Cyclones.htm, acesso em 02 de setembro de 2015.

EVANS J.L.; BRAUN, A. A Climatology of Subtropical Cyclones in the South Atlantic. J. Climate, v. 25, n. 21 p. 7328-7340, 2012.

EVANS, J.L., GUISHARD, M.P. Atlantic Subtropical Storms. Part I: Diagnostic Criteria and Composite Analysis. Mon. Wea. Rev., v. 137, n. 7, p. 2065-2080, 2009.

EVANS, J.L.; HART, R.E. Objective Indicators of the Life Cycle Evolution of Extratropical Transition for Atlantic Tropical Cyclones. Mon. Wea. Rev., v. 131, p. 909-925, 2003.

GAN, M.A.; RAO, V.B. Surface Cyclogenesis over South America. Mon. Wea. Rev., v. 119, p. 1293-1302, 1991.

GAN, M.A.; RAO, V.B. The Influence of the Andes Cordillera on Transient Disturbances. Mon. Wea. Rev., v. 122, n. 6, p. 1141-1157, 1994.

GAN, M.A.; PIVA, E.; RAO, V.B. Catarina Cyclone: a hurricane-like cyclone over South Atlantic. In: Second Trorpex International Science Symposium - STISS, 2006, Landshut, Alemanha. World Meteorological Organization WMO, v. 1355, 2006.

GFS. Global Forecast System. Disponível em: ftp://nomads.ncdc.noaa.gov/GFS/analysis_only/, acesso em: 12 de dezembro de 2014.

GOZZO, L.F.; DA ROCHA, R.P. Air-sea interaction processes influencing the development of a Shapiro-Keyser type cyclone over the subtropical South Atlantic Ocean. Pure Appl. Geophys., v. 170, n. 5, p. 917-934, 2013.

GOZZO, L.F.; DA ROCHA, R.P.; REBOITA, M.S.; SUGAHARA, S. Subtropical Cyclones over the Southwestern South Atlantic: Climatological Aspects and Case Study. J. Climate, v. 27, p. 8543-8562, 2014.

GRAY, W.M. Global view of the origin of tropical disturbances and storms. Mon. Wea. Rev., v. 96, p. 669-700, 1968.
GREC-USP. Grupo de Estudos Climáticos da Universidade de São Paulo. Disponível em: www.grec.iag.usp.br, acesso em: 12 de outubro de 2014.

GUISHARD, M.P.; EVANS, J.L.; HART, R.E. Atlantic Subtropical Storms. Part II: Climatology. J. Climate, v. 22, p. 35743594, 2009.

GUISHARD, M.P. Atlantic subtropical storms: Climatology and characteristics. 158 pp., $\mathrm{PhD}$ thesis, Pa State Univ., University Park, 2006.

HART, R.E. A cyclone phase space derived from thermal wind and thermal asymmetry. Mon. Wea. Rev., v. 131, p. 585616, 2003.

HAWKINS, H.F.; IMBEMBO, S.M. The structure of a small, intense hurricane-Inez, 1966. Mon. Wea. Rev., v. 104, p. 418442, 1976.

HAWKINS, H.F.; RUBSAM, D.T. Hurricane Hilda, 1964. Mon. Wea. Rev., v. 96, p. 617-636, 1968.

HEBERT, P.H.; POTEAT, K.O. A satellite classification technique for subtropical cyclones. NOAA Tech. Memo. NWS SR-83, 22 pp., 1975.

HOLTON, J.R. An Introduction to Dynamic Meteorology. 4th ed. San Diego: Elsevier Academic Press, 2004.

KIDDER, S.Q., GOLDBERG, M.D.; ZEHR, R.M.; DEMARIA, M.; PURDOM, J.F.W.; VELDEN, C.S.; GRODY, N.C.; KUSSELSON, S.J. Satellite analysis of tropical cyclones using the Advanced Microwave Sounding Unit (AMSU). Bull. Amer. Meteor. Soc., v. 81, p. 1241-1259, 2000.

KNUTSON, T.R.; MCBRIDE, J.L; CHAN, J.; EMANUEL, K.; HOLLAND, G.; LANDSEA, C.; HELD, I.; KOSSIN, J.P.; SRIVASTAVA, A.K.; SUGI, M. Tropical cyclones and climate change. Nature Geoscience, v. 3, p. 157-163, 2010.

LENTERS, J.D.; COOK, K.H. On the Origin of the Bolivian High and Related Circulation Features of the South American Climate. J. Atmos. Sci., v. 54, p. 656-678, 1997.

MCTAGGART-COWAN, R.; BOSART, L.F.; DAVIS, C.A.; ATALLAH, E.H.; GYAKUM, J.R.; EMANUEL, K.A. Analysis of Hurricane Catarina (2004). Mon. Wea. Rev., v. 134 , p. $3029-3053,2006$

NOAA Optimum Interpolation (OI) Sea Surface Temperature (SST) V2. Disponível em: http://www.esrl.noaa.gov/psd/data/gridded/ data.noaa.oisst.v2.html, acesso em 14 de dezembro de 2014.

NOAA Satellite and Information Service. Disponível em: http://www.ncdc.noaa.gov/gibbs/, acesso em: 16 de dezembro de 2014.

PATERSON, L.A.; HANSTRUM, B.N.; DAVIDSON, N.E.; WEBER, H.C. Influence of Environmental Vertical Wind Shear on the Intensity of Hurricane-Strength Tropical Cyclones in the Australian Region. Mon. Wea. Rev., v. 133, p. 3644-3660, 2005.

PIVA, E.D.; MOSCATI, M.C.L.; GAN, M.A. Papel dos fluxos de calor latente e sensível em superfície associado a um caso de ciclogênese na costa leste da América do Sul. Rev. Bras. Meteor., v. 23, p. 450-476, 2008.

RANDEL, W.J.; STANFORD, J.L. The observed life cycle of a baroclinic instability. J. Atmos. Sci., v. 42, p. 1364-1373, 1985.

REBOITA, M.S.; DA ROCHA, R.P.; AMBRIZZI, T; SUGAHARA, S. South Atlantic Ocean Cyclogenesis Climatology Simulated by Regional Climate Model (RegCM3). Climate Dynamics, v. 35, p. 1331-1347, 2010. 
REBOITA, M.S.; DA ROCHA, R.P.; AMBRIZZI, T. Dynamic and climatological features of cyclonic developments over southwestern South Atlantic Ocean. Horizons in Earth Science Research, 6, Nova Science Publishers, p. 135-160, 2012.

REBOITA, M.S.; GAN, M.A.; DA ROCHA, R.P.; CUSTÓDIO, I.S. Ciclones em Superfície nas Latitudes Austrais: Parte I Revisão Bibliográfica. Rev. Bras. Meteor., v. 32, n. 2, p. 171-186, 2017.

REYNOLDS, R.W., SMITH, T.M.; LIU, C.; CHELTON, D.B.; CASEY, K.S.; SCHLAX, M.G. Daily High-ResolutionBlended Analyses for Sea Surface Temperature. J. Climate, v. 20, p. 5473-5496, 2007.

SATYAMURTY, P.; SANTOS R.P.; LEMS, M.A.M. On the stationary trough generated by the Andes. Mon. Wea. Rev, v. 108 , p. $510-520,1980$.

SCHULTZ, D.M.; KEYSER, D.; BOSART, L.F. The effect of large-scale flow on low-level frontal structure and evolution in midlatitude cyclones. Mon. Wea. Rev., v. 126, n. 7, p. 1767-1791, 1998.
SELUCHI, M.E.; SAULO, C.; NICOLINI, M.; SATYAMURTY, P. The Northwestern Argentinean Low: A Study of Two Typical Events. Mon. Wea. Rev., v. 131, p. 2361-2378, 2003

SHAPIRO, M.A.; KEYSER, D. Fronts, jet streams and the tropopause. Extratropical Cyclones, The Erik Palmén Memorial Volume, C. W. Newton and E. O. Holopainen, Eds., Amer. Meteor. Soc., p. 167-191, 1990.

SOUTHERN HEMISPHERE TROPICAL CYCLONE DATA PORTAL. Disponível em: http://www.bom.gov.au/cyclone/history/tracks/, acesso em 08 de agosto de 2014.

STULL, R.B. Meteorology for Scientists and Engineers. $2^{\text {nd }}$ Ed., Brooks/Cole, 2000.

TROUP, A.J.; STRETEN, N.A. Satellite-Observed Southern Hemisphere Cloud Vortices in Relation to Conventional Observations. J. Appl. Meteor., v. 11, p. 909-917, 1972.

VERA C.S.; VIGLIAROLO, P.K.; BERBERY, E.H. Cold Season Synoptic-Scale Waves over Subtropical South America. Mon. Wea. Rev., v. 130, p. 684-699, 2002.

This is an Open Access article distributed under the terms of the Creative Commons Attribution Non-Commercial License which permits unrestricted non-commercial use, distribution, and reproduction in any medium provided the original work is properly cited. 